\title{
«Creo en Dios, Padre y Creador»
}

\section{FE Y CONFESIÓN DE FE *}

El Símbolo es la personal o comunitaria piofesión pública de fe cristiana en el único Dios, autorrevelado como Padre, Hijc y Espíritu Santo a través de su respectiva obra salvífica y, como tal, anunciado desde sus orígenes apostólicos por la Iglesia ${ }^{1}$. Aquél sintetiza, por tanto, el objeto de la fe cristiana ${ }^{2}$ públicamente profesada. Ambos elementos - fe y confesión- envuelve. pues, ya su aserción introductora «creo en»: Expresa tanto 1) la fe justificante como 2) la confesión salvadora ( $\mathrm{Rm} 10,10)$ del creyente cristiano, devenido tal por haber escuchado la predicación de la Palabra $(\mathrm{Rm} \mathrm{10,17).}$

\section{LA FE CRISTIANA}

Además de la bibliografía citada, Cf.: A. SCHLATTER, Der Glaube im NT, Suttgart ${ }^{4} 1927$; P. ANTOINE, Foi: DBS III 276-310; A. WEISER-R. BultMANN, Pistéuo: ThWNT VI 174-230; AA.VV., Qu'est-ce que la foi?: LumVie 22-23 (1955); AA.VV., Foi: Cath. IV, 1370-97; AA.VV., Glaube: RGG II 1586-1611; AA.VV., Glaube: LThK IV 913-25; E.C. BLACKMAN, Faith: IDB II 222-34; J. AUER, Was heisst glauben?: MThZ 13 (1964) 235-55; Id., Dios uno y trino, Barcelona 1982, 25-37; K. RAHNER, Sobre la posibilidad de la fe hoy: «Escritos de Teología», V, Madrid 1964, 11-31: A. QueralT, Fe: EncBibl III 482-99; G. EBE1.ING, Das Wesen des christlichen Glaubens, Tübingen 1959 (trad. españ., Madrid 1974): J.B. BAIIeR-H. ZimmermanN. Fe: DTR 387-404: H. URS von BalthaSAR, I:nsavos teológicos, II, Madrid 1964. 57-76: Id . Sirggi Teologici, III, Brescia 1972, 1 -87; Id., Gloria, I, Milano 1975, 117-322; G. Pozo, Teología de la fe, Granada . 966; J. TRÜSCH-J. PFAMMTER, La fe: MS I 877-993; AA.VV., Fe: SM III 95-140; R. SCHNACKENBURG, Existencia cristiana según el NT, I, Estella 1970, 77-107; AA.VV., Qu'est-ce que croire?: LumVie 98 (1970) 5-120; W. KASPER, Einführung in den Glauben, Mainz 1972 (trad. españ., Salamanca 1976); K.H. SCHELKLE, Teología del NT, II, Barcelona 1976, 370-93; J. DuPONT, Fe: VTB 327-35; M. iECKLER, Fe: CFT I 562-81; H.J. HERMISSON-E. LOHSE, Glauben, Suttgart 1978; '). LUHRMANN, Glaube: RAC XI 48-122. Más bibliografía: Infra. nn. 4 y 150.

«i.Qué significa creer?». Una pregunta incesantemente formulada por el hombre hodierno. Y es normal. Pues la fe en Dios ha dejado de ser evidente para quien, en lugar de «sus huellas», ve por doquier «los vestigios del hom-

\footnotetext{
* Cf.: F. Kattenbusch, Das apostolische Symbol, II, Leipzig 1900, 501-15; C. Eichenseer, Das Symbolum Apostolicum beim hl. Augustinus, St. Ottilien 1960, 157-63; H. de Lubac, La foi chrétienne. Essai sur la structure du Symbole des Apôtres, Paris 1968, 131-254; J. Ratzinger, Einführung in das Christentum, München 1968, $17-69$ (trad. españ., Salamanca 1971, 19-74); W. Beinert, Das Glaubensbekenntnis der Oekumene, Freiburg 1973, 41-49; W. Pannenberg, La fe de los Apóstoles, Salamanca 1975, 13-27; J.N.D. Kelly, Early christian Creeds, London ${ }^{31976,}$ 30-61 (trad. españ., 47-58); Ph. Schäfer, Einführung in das Glaubensbekenntnis, Mainz 1979, 17 23 (trad. españ., Santander 1983, 23-32); Card. A. Renard, Je crois, en: «La foi de l'Eglise», Paris 1978, 47-80; J. Martín, Creo en Dios Padre, en: «El Credo de los cristianos», Madrid 1982, 12 32:12-19; F. Sebastián, Yo creo, en: «El Credo», Madrid 1982, 11-24.

1. Cf. suprid, 12-17. 2. Cf. supra, 4-5.
} 
bre» o su dominio sobre la tierra y el cosmos. ¿Es, pues, aún posible creer en Dios y en Jesucristo? He aquí el interrogante fundamental e ineludible: Se lo formulan hoy muchos cristianos, infantiles en su fe; también se lo plantean al cristiano, adulto en ella, los numerosos militantes del ateísmo, «uno de los fenómenos más graves de nuestro tiempo" ${ }^{3}$. Urge, por tanto, responder a esa pregunta con valentía y claridad. Para ello, podemos pedir esa respuesta a los hodiernos creyentes adultos o, más bien, suplicarla al respectivo testimonio de la Biblia, el Libro de la fe.

1. Eso es ya, en efecto, el AnTiguo Testamento (Cf. Hebr 11,2-39) ${ }^{4}$, como lo refleja el rico significado teológico de su vocabulario sobre la fe y, sobre todo, el testimonio elocuente de sus creyentes:

1) Un rápido análisis del vocabulario veterotestamentario ${ }^{5}$ muestra ya, que emuná $(=\mathrm{fe}$ ) proviene de la raíz verbal amán ( = ser firme, seguro, fiable) $y$, en el uso de su forma «nifal» (=tener estabilidad), el participio neemán (LXX: «pistós») designa cosas estables o duraderas y firmes ${ }^{6}$ así como personas leales ${ }^{7}$ o fieles tanto a los hombres ${ }^{8}$ como a Dios ${ }^{9}$, quien asimismo «es fiel» o, más exactamente, «el Dios fiel» ${ }^{10}$. Por eso se puede confiar plenamente en Él y fiarse de su palabra. Este significado envuelve la forma «hifil» he'emîn: Designa la credibilidad total prestada (o rehusada) no sólo a un hombre o a su mensaje ${ }^{11}$ sino también a un mensajero de Dios ${ }^{12}$ y a Él mismo, como al único Dios salvador ${ }^{13}$; también traduce la confianza plena en un hombre ${ }^{14} \mathrm{y}$, sobre todo, en Dios ${ }^{15}$ : En Él confiaron plenamente o «creyeron

3. Conc. Vat. II. Const. GS 19 . 4. A este respecto, además de la bibliografía indicada (supra), así como de los artículos sobre la fe (P. Antoine, DBS III 276-291; A. Weiser, ThWNT VI 182-97; J. Duplacy, Cath. IV 1370-73; F. Baumgärtel, RGG II 1588-90; R.Schnackenburg, LThK IV 913s; E.C. Blackman, IDB II 222-23.225-27; J.B. Bauer, DTB 387-91; J. Dupont, VTB 328-31; M. Seckler, CFT I 562s; D. Lührmann, RAC XI 55-59.62s; H. Wildberger, DTMAT I 276-319; A. Jepsen, DTAT I 309-43) y los estudios de las teologías bíblicas (P. van Imschoot, Théologie de l'AT, II, Tournai 1956, 101-3; W. Eichrodt, Teología del AT, II, Madrid 1975, 28092; M. García Cordero, Teología de la Biblia, I, Madrid 1970, 595-98), Cf.: B. Bach, Der Glaube nach der Anschauung des AT (BFChT IV.6), Gütersloh 1900; P. Michalon, La foi, rencontre de Dieu et engagement envers Dieu, selon l'AT: NRTh 75 (1953) 587-600; A. Gelin, La foi dans l'AT: LumVie 22 (1955) 7-18; E. Pfeiffer, Glaube im AT: ZAW 71 (1959) 151-64; S. Virgulin, $L a$ «fede» nella profezia d'Isaia, Milano 1961; J. Pfammatter, La fe según la S. Escritura. A: El AT: MS, I 883-85; K.H. Schelkle, Teología del NT, II, Barcelona 1976, 371-79; J. Körner, Das Wesen des Glaubens nach dem AT: ThLZ 104 (1979) 713-20. . 5. Cf.: A. Schlatter, o.c., 55565.576s; P. Antoine, a.c., 27.6-78; A. Weiser; a.c., 183-86.191-95; E. Perry, The meaning of «emuna» in the OT: JBR 21 (1953) 252s; E. Pfeiffer, a.c.; S. Virgulin, o.c., 27-49; E.C. Blackman, a.c., 222s; R. Smend, Zur Geschichte von «he'emîn», en: «Fs. W. Baumgartner» (Suppl. VT 16), Leiden 1967, 284-90; H. Wildberger, «Glauben». Erwägungen zu «he'emín», en: Ib., 376-86; Id., «Glauben» im AT: ZThK 65 (1968) 129-59; Id., Aman: DTMAT I 276-319; A. Jepsen, 'Aman: DTAT I $309-43$. 6. Is $22,23.35 ; 36,16$; Jer 15,$18 ;$ Dt 28,59 . 7. Prov 25,13; 27,6. 8. 1 Sam 22,14 ; Neh 13,13. 9. Núm 12,7; 1 Sam 2,35; Is 8,2 ; Eclo 44,20. 10. Is 49,7; Jer 42,5; Dt 7,9. 11. Gén 45,26; 2 Crón 32,$15 ; 1 \operatorname{Re} 10,7$. 12. Éx 4,1.8.9; Is 53,1. 13. Is 43,10s; Dt 9,23; Sal 106,24. 14. Moisés (Éx 14,31; 19,9), David (1Sam 27,12), los profetas (2Crón 20,20). 15. Gén 15,6; Éx 14,31; Jon 3,5; Cf. Éx 4,31; Is 7,9; 28,16. Por eso 
los Ninivitas» a raíz de la predicación de Jonás sobre su inminente juicio ${ }^{16}$; en Él confió plenamente o «creyó» Israel, tras «haber visto» su «mano fuerte» desplegada «contra los egipcios» en el Mar Rojo, es decir, su poder salvador ${ }^{17}$; en Dios sólo debe «creer» o apoyarse «la casa de David», para asegurarse «la estabilidad» perpetua de la promesa divina al gran Monarca ${ }^{18}$; así lo hizo Abraham, quien, a pesar de la humanamente irrealizable promesa divina sobre un hijo heredero y una incontable descendencia ${ }^{19}$, "creyó en Jahveh» ${ }^{20}$ o tomó en serio aquella promesa y se apoyó totalmente en el poder de su Autor, confiando plenamente en Quien consideró «poderoso aun para resucitar de entre los muertos» y, por tanto, también «para cumplir lo prometido» ${ }^{21}$, dando por esa fe (o confianza total en el poder divino) «gloria a Dios», quien «se la reputó por justicia» ${ }^{22}$. El justo ante Dios o «creyente» ${ }^{23}$ en Él es, pues, quien se apoya totalmente en su omnímodo poder vivificante y salvador, confiando plenamente en el Dios todopoderoso y fiel. Esto último, en efecto, es Dios (Cf. supra), por definir la émeth (= fidelidad) su mismo ser: Si con respecto al hombre designa ese vocablo su fidedignidad ${ }^{24} \mathrm{o}$ veracidad ${ }^{25}$, aplicado a Dios le define como «un Dios de fidelidad» ${ }^{25 a}$ tanto en palabras como en obras ${ }^{26}$, por la que le alaban quienes la experimentaron ${ }^{27}$, debiendo éstos «con fidelidad» no sólo invocarle sino también servirle ${ }^{28}$. Creyente es quien ha experimentado en su vida al Dios fiel y, por eso, le invoca y sirve con fidelidad o firmeza interior. La actitud o conducta estable, radicada en la fidelidad, traduce precisamente el vocablo emuná (LXX: «pístis»), designando fundamentalmente «conducta honrada, recta, estable, leal o fiel». $\mathrm{Si}$, aplicado a Dios, expresa ese vocablo el estable o firme comportamiento leal del «Dios fiel» como «la roca» ${ }^{29}$, siendo por tanto su «lealtad grande» y perpetua ${ }^{30}$, pues todo lo realiza «en lealtad» o con su característica fidelidad amorosa ${ }^{30 a}$, por la que se le suplica y alaba ${ }^{31}$, con respecto a los hombres designa su conducta estable y honrada ${ }^{32}$, sincera o veraz ${ }^{33}$, fiel a Dios: Esta firmeza interior o conducta estable y fiel para con Él es propia del «pueblo justo», integrado por quienes (=los creyentes) «guardan la fidelidad» o «confían siempre en Dios» y en Él se apoyan como en «una Roca eterna» ${ }^{34}$; por esa «conducta fiel» a Dios, por tanto, se mantendrá siempre en pie o «vivirá el justo» ${ }^{35}$.

«el creyente» espera en (= «yahal») Dios (Cf. A. Weiser, a.c., 194.196; C. Westermann, DTMAT I 1001-5:1002s) y se refugia (= «hasah») en Él: Cf. A. Weiser, a.c., 193; E. Gerstenberger, DTMAT I 861-64:863. 16. Jon 3,4-5. 17. Éx 14,31; Cf. Sal 106,12. 18. Is 7,2-9:v.9; Cf. 2Sam 7,12-16par. 19. Gén 15,4-5; Rm 4,18-19. 20. Gén 15,6a. 21. Hebr 11,19; Rm 4,17.21. 22. $\operatorname{Rm} 4,20.22$ (= Gál 3,6): Gén 15,6 b. 23. Sal 101,6; 31,24 . 24. Gén 42,16; Éx 18,21; Neh 7,2. 25. Os 4,1; Jer 9,4; Is 59,14s. 25a. Sal 31,6. 26. Éx 34,6; Sal 86,15; 2Sam 7,28; Neh 9,33 27. Sal 71,22; Cf. 40,11; 138,2. 28. Jer 4,2; Jos 24,14; 1Sam 12,24; $1 \operatorname{Re} 2,4$. 29. Dt 32,4. 30. Lam 2,32; Sal 36,6; 100,5; 119,90. 30a. Sal 33,4; 96,13; $89,2-3.25 .34 .50 ; 98,3$. 31. Sal 143,$1 ; 89,2$ s. 32. Ex 17,12; $2 \operatorname{Re} 12,16 ; 1$ Crón 9,22 ; 19,9. 33. Jer 5,1 ; Is 59,4 ; Prov 12,$22 ; 20,6$; Sal 12,$2 ; 31,24$. 34. Is $26,2-4$. 35. Hab 2,4 . 
El vocabulario veterotestamentario muestra, pues, que la fe en Dios no es «un interrogante» sino una certeza y seguridad, no es «un salto en el vacío» o «en el abismo infinito» sino el firme apoyo en la experimentada lealtad salvífica del Dios tan «fiel» como «la roca» ${ }^{36}$, a cuya palabra se puede dar pleno crédito con el ratificador amén (= «así es») ${ }^{37}$, y en quien se puede confiar totalmente. "Creer en Dios» significa, pues, no sólo la credibilidad total dada a su palabra sino también la confianza plena en Él y la estable conducta leal para con Él, basada aquélla y éstas en la previa experiencia personal de su omnipotente y salvador comportamiento fiel.

2) Es lo que refleja, por lo demás, la vida de los más relevantes creyentes del AT, o quienes fueron «alabados por su fe» en Dios y de ella son «testigos» nuestros ${ }^{38}$ :

a) Ya el «pastor» ABEL mostró su fe en Dios (Hebr 11,4), - a quien todo primogénito animal pertenece ${ }^{39} \mathrm{y}$, por tanto, se le debe sacrificar ${ }^{40}$ en signo de reconocimiento y sumisión- ${ }^{41}$, ofreciéndole «los primogénitos de su rebaño» con sus «grasas» ${ }^{42}$ y reconociéndole así no sólo único Autor de la vida sino también Señor supremo de sus posesiones o ganados, de su propia historia: ¡Eso es la fe! Con análoga fe (Hebr 11,5-7) «agradó a Dios» HENOC, «caminando con» Él ${ }^{43}$. Y temeroso le obedeció «el justo» NoÉ, ejecutando «cuanto le ordenó Jahveh» ${ }^{44}$ : Creer en Dios significa caminar con Él o agradarle, mediante la obediente sumisión a su voluntad.

b) Del todo paradigmática es, a este respecto, la fe de ABRAHAM ${ }^{45}$, el «justo» y «amigo de Dios» ${ }^{46}$, que fue «fiel» a Él y devino «padre de todos los creyentes» ${ }^{47}$ así como su insuperable modelo veterotestamentario. Pues la

36. Dt 32,4 ; Cf. Is 26,$4 ; 28,16$; Sal 62,8 ; $71,3-6$. 37. Cf. Jer 11,$5 ; 28,6$. 38. Hebr 11,2-39; 12,1. 39. Éx 22,29; 34,19; Cf. 13,12; Lev 27,26; Dt 15,19. 40. Cf. Éx 13,15; Dt 15,19s; Núm 18,17; Lev 3,16. 41. Cf. G. von Rad, Teología del AT, I, Salamanca 1972, 321. 42. Gén 4,2.4: Hebr 11,4b. 43. Gén 4,22.24: Hebr 11,5. 44. Gén $6,9.22 ; 7,1.5$ : Hebr 11,5. La fe del «justo» Noé, quien «caminaba con Dios» (Gén 6,9), fue probada por Él con la orden de construir «un arca» (Gén 6,14-17) - iun barco en tierra firme! - y «entrar en» ella (Gén 7,1-4), superando esa prueba de su fe con la ejecución de «cuanto le ordenó Jahveh» (Gén $6,22 ; 7,5)$ y siendo por ello, entonces, «el único justo» en la tierra (Gén 7,1): Cf. G. von Rad, $E l$ libro del Génesis, Salamanca 1977, 144s. 45. Gén 11,26-25,10 (Cf. Hebr 11,8-19): «No cabe la menor duda de que tras estos relatos sobre Abraham se oculta el problema de la fe» (G. von Rad, o.c., 225), como lo muestra ya su reiterada evocación neotestamentaria (Hebr 11,8-19; Gál 3,6-9; Rm 4; Sant 2,18-24; Jn 8,56); Cf. a este respecto: P. Dornstetter, Abraham (BSt VII 2-3), Freiburg 1902; L. Pirot, Abraham: DBS I 8-28:16ss; J. Daniélou, Abraham, père des croyants (CSION 5), Paris 1951; J. Lecuyer, Nuestro padre Abraham, Madrid 1955, J. Jeremías, ThWNT I 7-9; V. Hamp-J. Schmid, Abraham: LThK I 56-58; A. Perrot, Abraham et son temps, Neuchâtel 1962; L. Hicks, Abraham: IDB I 14-21; J. Prado, Abraham: EncBibl I 60-83; R. Kilian, Die vorpriestlichen Abrahamsüberlieferungen literarkritisch und traditionsgeschichtlich untersucht, Bonn 1966; O. Schilling, Abraham: DTB 1-5; R. Feuillet-A. Vanhoye, Abraham: VTB 38-41; G. von Rad El libro del Génesis, 201ss. Más bibliografía: Infra, n. 77 . 46. Sab 10,6; Is 41,8 (=Sant 2,23). 47. Eclo 44,20; Gál 3,9; $\mathrm{Rm} \mathrm{4,11.} \mathrm{Con} \mathrm{acierto} \mathrm{es,} \mathrm{pues,} \mathrm{designado} \mathrm{Abraham} \mathrm{el}$ 
tradición histórica sobre el gran Patriarca ${ }^{48}$ fue interpretada por los dos más antiguos teólogos de Israel -el Jahvista y el Eloísta- a la luz de su propia experiencia de Dios, ofreciéndonos así la teología histórica de la fe o, más bien, la historia teológica del creyente paradigmático.

En efecto, antes de ser llamado por Dios (Gén 11,26-31) es Abraham, hijo de Téraj y casado con la estéril Sara ${ }^{49}$, un pastor nómada de la mesopotámica Ur ${ }^{50}$, donde con sus familiares «servía a otros dioses» ${ }^{51}$. Un hombre, pues, cualquiera y ciertamente religioso, que se ganaba la vida pastoreando errante su ganado. ¡Cómo tantos de su tierra y en su época! ${ }^{52}$. Con una excepción: Al sorprenderle la Voz divina (Cf. infra) era ese pastor un viejo fracasado y sin esperanza. Pues a los «75 años» (Gén 12,4) aún no poseía los dos bienes más anhelados por un nómada oriental: Una tierra propia (Cf. Gén 11,31 ), donde poder no sólo sedentarse sino también construir su sepulcro y asegurarse así la tranquila permanencia en el «sheol» ${ }^{53}$, y un hijo heredero ${ }^{54}$ que, prolongando su nombre y adquiriendo su hacienda, diese sentido a su vida. Sin duda que el religioso Abraham habría pedido reiteradamente esos dos bienes a sus dioses, quienes sin embargo le respondieron siempre con el ya inaguantable silencio, que provocó en el idólatra - iqué duda cabe! - un escepticismo total: El fracasado y desesperado marido de Sara es ahora también un perfecto ateo.

Precisamente en esta situación - ¡la más propicia! - tiene lugar su vocación a la fe por Jahveh ${ }^{55}$, quien le promete el don de una «tierra» y de «una nación grande», asegurado este último por la reiterada y universal «bendición» divina de la fecundidad sexual ${ }^{56}$. A una condición: Dejar su país y romper con todas sus vinculaciones naturales, para emigrar a «la tierra» por él del todo ignora, pero que Dios «le mostrará» (Gén 12,1). ¡Exigencia terrible para un antiguo nómada oriental, profundamente arraigado a su país y a su clan patriarcal! Pero Abraham tiene que optar por morir desesperado o aferrarse a esa promesa de Dios, obedeciendo incondicionalmente a su exigencia y abandonándose totalmente a su guía: ¡Estaba ante una alternativa!

El nómada de Ur optó por este último: «Marchó, como se lo había dicho

«segundo padre del género humano» o el «padre de la fe», quien por ello precisamente «reviste una importancia absoluta en el orden del espíritu»: S. Kierkegaard, Temor y temblor, Madrid 1976, 33.169. 48. Sobre el núcleo histórico de los relatos patriarcales (Gén 12-35), Cf.: H. Cazelles, Patriarches: DBS VII 96-120; R. de Vaux, Historia antigua de Israel, I, Madrid 1975, 193223. 49. Gén 11,27.29-30; Cf. 16,1-2; Rm 4,19. 50. Gén11,19.31; 12,8-9; 13,3. 51. Jos 24,2; Jdt 5,7. 52. Cf. R. de Vaux, o.c., I 226-35. 53. Puesto que en la concepción antigua sobre los muertos la duración del cuerpo o, al menos, de sus huesos asegura la subsistencia del alma (=«nefesh») en la tranquila morada del «sheol» (Cf. Jb 26,5-6; Is 14,9-10; Ez 32,17-32), era de suma importancia proveer a los difuntos de una sepultura (Cf. 2Sam 21,8-14), evitando así la más terrible maldición divina: Ser comido por las aves o las bestias (Cf. $1 \operatorname{Re} 14,11$; Jer 16,46;22,18s; 29,5) y desaparecer así en la nada total, siendo por tanto la privación de la sepultura una desgracia tremenda (Cf. Sal 79,3) reservada a los impíos (1Re 14,11; Jer 22,18s); Cf. R. de Vaux, Instituciones del $A T$, Barcelona 1964, 94s. 54. Cf. Gén 16,2-3. 55. Gén 12,1-3: Hebr 11,8a. 56. Gén 12,2b3; Cf. $1,22.28$. 
Jahveh», naciendo entonces «la fe» de quien, «al ser llamado por Dios, obedeció y salió... sin saber a dónde iba» ${ }^{57}$. Creer en Dios significa, pues, escuchar y tomar en serio su promesa salvífica, obedeciendo sin razonar a su exigencia y caminando sólo bajo su guía. ¡No a ciegas! Pues el caminar-con-Dios de la fe ${ }^{58}$ tiene un punto de partida y una meta muy concreta: Abraham partió desde la idolátrica Ur y Jarán hasta «llegar a Canaán», donde dio culto «a Jahveh e invocó su nombre» ${ }^{59}$, cambiando por tanto su previo «servicio a los dioses» (Cf. supra) por el culto al Dios de la promesa. ¡Un paso enorme, realizado sin duda por la ya fe inicial del anciano Patriarca! Pues ese cambio traduce, en rigor, la conversión o paso a la fe de quienes han abandonado la servidumbre a los ídolos de este mundo para servir al verdadero Dios ${ }^{60}$.

Esa fe incipiente, sin embargo, necesita llegar a ser fe probada, como lo fue seguidamente la de Abraham: Sometido a la prueba inicial del «hambre» (Gén 12,10a), decidió ir «a Egipto» (!) y superar así aquélla personalmente, sin contar con Dios, incurriendo sin embargo por ello en gravísimos líos y debiendo sufrir finalmente la vergüenza de pasar, ante el faraón, por manifiesto mendaz y persona no grata ${ }^{61}$. Había recibido una instructiva lección: iSin Dios, no es posible superár la prueba de la fe y sí es cierto -tras muchas penalidades-el fracaso total de aquel intento!

El de Abraham contribuyó, sin duda, a que su fe inicial en Dios deviniese la fe fuerte de quien, en adelante, cuenta siempre con Él y sólo en su poder se apoya ${ }^{62}$. Tras regresar «de Egipto» al «lugar donde había invocado el nombre de Jahveh», vio «multiplicada su hacienda» y «se estableció en Canaán», donde nuevamente le fue prometido el don de «toda la tierra» por el Dios ${ }^{63}$ fiel, Quien efectivamente «entregó a sus enemigos en sus manos» ${ }^{64}$. ¡La inicial promesa divina era ya, en parte, realidad concreta! Lo que reafirmó la confianza de Abraham en Quien lo llamó y probó. Con esa primera experiencia personal del Dios fiel y segura garantía de su poder, en efecto, «se vigorizó la $f e$ » de aquél $(\mathrm{Rm} 4,20)$ ante la nueva - humanamente irrealizable- promesa divina de "un hijo heredero» y de una incontable "descendencia» ${ }^{65}$, pues, «sin considerar» o atender a su ancianidad y a la esterilidad de su mujer,

57. Gén 12,4a: Hebr 11,8b-c. 58. Cf. Gén 5,22.24; 6,9. 59. Cf. Gén 15,7; 12,4b-8. 60. Cf. 1 Tes 1,9; Act 14,15. 61. Cf. Gén 12,10-20: A la tentación de «descender» 0 «volver a Egipto», tras la prueba del «hambre» en Canaán, caerán también los patriarcas Isaac (Cf. Gén 26,1-2) y Jacob (Cf. Gén 41,57b-42,2; 43,1-2) así como el pueblo de Israel (Cf. Éx 16,2-3; Núm $20,2-5 ; 21,5)$. El Jahvista introdujo e interpretó, pues, con toda probabilidad el relato sobre el descenso de Abraham a Egipto y su retorno a Canaán (Gén 12,10-13,1) a la luz de la respectiva prueba sufrida por Israel, es decir, «como preanuncio del futuro descenso (a Egipto) y del futuro éxodo» del Pueblo (E. Testa, Dall'Egitto à Canaan. Le chiamate di Dio alla libertà, Assisi 1975, 19-35:22-28). Sólo a la luz de ese contexto adquiere pleno sentido esta primera prueba de la fe de Abraham (muy bien subrayado por G. von Rad, El libro del Génesis, 294), sin cuyo trasfondo es ése «un relato muy chocante y de nada fácil explicación»: G. von Rad, o.c., 203. 62. Gén 13,1-15,6; Cf Rm 4,18-22:v.20. 63. Cf. Gén 13,1-18. 64. Gén 14,1-24:v.20. 65. Gén 15,1-5; Cf. Rm 4,18. 
«contra toda esperanza» humana «creyó Abraham en Dios» o se apoyó única y totalmente en su poder "para cumplir lo prometido», dando así «gloria a Dios» con esa fe, Quien por ello «se la reputó por justicia» ${ }^{66}$. Lo que significa: La recta conducta o «justicia» ante Dios es efecto normal de la fe robusta en Él, por la que el creyente, fortalecido con la experiencia personal de su fidelidad, toma totalmente en serio la nueva promesa de Dios y a Él se confía sin reservas, apoyándose sólo y por completo en su poder. Esa es la fe, que justificó ante Dios a Abraham y justifica a cuantos «creemos en Aquél, que resucitó de entre los muertos a Jesús, Señor nuestro» ${ }^{67}$ : ¡Sólo esa fe justifica!

No es aún, sin embargo, fe adulta, para lo cual necesita - como la de Abraham- madurarse con la crisis y solidificarse con la sólida garantía de un nuevo don concreto ${ }^{68}$ : Una y otro robustecieron la fe del Patriarca. En efecto, el cumplimiento sobre la promesa divina del «hijo» se demoraba y, a «los 86 años», el marido de la estéril Sara fracasó en su intento por cumplir personalmente aquélla con la esclava de su mujer, Agar, quien efectivamente «le dio su hijo Ismael» ${ }^{69}$ : ¡No era ése, sin embargo, «el hijo de la promesa»! $\mathrm{Cu}$ yo don se retarda inaguantablemente. Aun no lo ve Abraham a sus «99 años», cuando Dios «se le aparece» y con «alianza eterna» le asegura «ser padre de numerosos pueblos», mediante «el hijo» que Él le dará... ¡ de la estéril y anciana Sara! ${ }^{70}$ Pero, "¿a un hombre de 100 años va a nacerle un hijo? ¿Puede acaso Sara dar a luz a sus 90 años?»: Así reacciona «en su interior» el viejo Abraham a la nueva promesa divina, «riéndose» (sic!) de ella como «se reirá» (sic!) luego Sara ${ }^{71}$. La crisis en su fe en Dios es, pues, total. Superada, sin embargo, por el Dios fiel, Quien le renueva la promesa del «hijo» y se la reitera luego a su incrédula mujer, para un plazo de tiempo - «el año próximo»muy concreto, pues: «¿Hay algo imposible para Jahveh?» ${ }^{72}$. ¡Nada! Esto implica esa pregunta ${ }^{73}$, con la que el Dios omnipotente y fiel vencerá la burlona e incrédula «risa» de Sara, quien efectivamente, «en su vejez» y «en el plazo predicho por Dios, concibió y dio un hijo a Abraham», por él llamado «Isaac» (= se rió): El «hijo de la risa» o incredulidad de aquéllos y, también «el hijo de la promesa» o memorial viviente del omnímodo poder del Dios fiel ${ }^{74}$. Así se mostró, cumpliendo finalmente la reiterada promesa de la «tierra» y del «hijo», fruto también ambos de la inicial, probada, vigorizada y ahora adulta fe de Abraham. Lo que significa: Lejos de ser la fe en Dios algo incierto e inseguro, se apoya más bien sobre la sólida garantía de dones tan concretos, como por ejemplo lo son una tierra y un hijo. Con la garantía de esos dones o indiscutibles signos de credibilidad en la existencia y poder de Jahveh respondería sin duda Abraham, a quien le interrogase «si cree en Dios» y «por qué»: «¡Mira lo que milagrosamente me ha dado mi encuentro

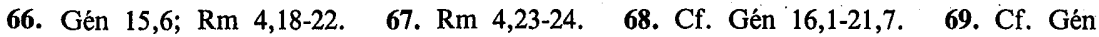
16,1-16:vv.4b-6. 70. Cf. Gén 17,1-16. 71. Cf. Gén 17,17; 18,12-15. 72. Gén 17,19-21; 18,9-15:vv.9-14. 73. Cf. Lc 1,37; Mc 10,27par. 74. Gén 21,1-7; Cf. Gál 4,28; 9,6-9. 
con Él y mi total confianza en su promesa!». La duda radical -es evidenteno puede ya morder en esa fe adulta de Abraham, concretizada tanto en $s u$ «tierra» como -isobre todo! - en $s u$ «hijo» Isaac. Y, siendo éste figura de Cristo ${ }^{75}$, la piqueta de aquella duda tampoco puede mellar la fe adulta de aquellos, a quienes el recibido «Espíritu del Hijo de Dios» y su «grito ¡Abbá, Padre! en nuestros corazones prueba que somos hijos de Dios» ${ }^{76}$ o creyentes en el Dios de Abraham y de Jesucristo.

La fe adulta de Abraham «alcanzó su perfección», sin embargo, «cuando ofreció a su hijo Isaac sobre el altar» (Sant 2,21): Tras la gran prueba ${ }^{77} \mathrm{de}$ aquél por Dios, ordenándole «ofrecer en holocausto» a su "tanto amado»e idolatrado «único hijo» Isaac ${ }^{78}$. ¡Una exigencia terrible! Lo era para todo padre y, especialmente, para Abraham: Sacrificar a su «único hijo», fruto de la pasada promesa divina sobre su futura «descendencia numerosa», significaba en rigor para el vetusto Patriarca renunciar a su pasado y a su futuro, dar un puntapié a su vida y, más aún, aceptar el absurdo de la humanamente incomprensible autocontradicción de Dios. Pues, ¿no se contradecía humanamente Quien antes le prometió el don de «un hijo» y de él «un gran pueblo» ${ }^{79}$, exigiéndole ahora sacrificar a ese «único hijo»? ¡Sin duda! Y, sin embargo, para el teólogo Eloísta no envolvía esa exigencia divina contradicción alguna en el único Dios salvador, Quien en su servicio y amor no admite rivales ${ }^{80}$. El protagonista de su relato, por tanto, sabía bien esto. Si, pues, Abraham obedeció enseguida - «muy de madrugada»- a la orden de Dios, lo hizo sin duda «por la fe» ${ }^{81}$ adulta en el Dios fiel a sus promesas: Por esa fe «se puso en marcha hacia» el monte Moria (Gén 22,3b), «contento como si fuera a una fiesta» ${ }^{82}$;

75. Cf. Gál 3,15; Hebr 11,19. 76. Gál 4,6; Rm 8,15-16. 77. Gén 22,1-19. Sobre este artístico y genial relato del Eloísta, con «temor y temblor» o dramatismo existencial parafraseado por Soren Kierkegaard (Temor y temblor, Madrid 1976), además de la bibliografía citada (supra, n. 45) y de los Comentarios al Génesis (Cf. G. von Rad, o.c., 292-301; C. Westermann, Genesis [BKAT I.2], Neukirchen-Vluyn 1981, 429-47: bibliogr.), Cf.: D. Lerch, Isaaks Opferung christlich gedeutet (BHTh 12), Tübingen 1950; J. Daniélou, Les figures du Christ dans l'AT, Paris 1950, 95-111; M. Buber, Le sacrifice d'Isaac: DViv 22 (1952) 69-76; I. Maybaum, Die Opferung Isaaks: EvTh 17 (1957) 249-64; Id., 'Aqeda. The sacrifice of Isaac, London 1959; L. Le Deaut, La nuit pascale (AB 22), Roma 1963, 131-212; H.G. Reventlow, Opfere deinen Sohn! Eine Auslegung von Gen 22 (BSt 53), Freiburg 1968; R. Kilian, Isaaks Opferung (SBS 44), Stuttgart 1970; G. von Rad, Das Opfer des Abrahams, München 1971; R. Lack, Le sacrifice d'Isaac: Bibl 56 (1975) 1-12; R.J. Daly, The soteriological significance of the sacrifice of Isaac: CBQ 39 (1977) 45-75; S. Sabugal, Abbá... La Oración del Señor, Madrid 1984, 696-98. 78. Gén 22,2. Esa idolatrización de Isaac por Abraham está ya reflejada en la frase «tu hijo, tu único, al que amas» (v. 2a), insinuando con ello el Eloísta, que Abraham «lo prefiere a todo» (Jub 17,16) y consistiendo la prueba en mostrar «si la vida de su hijo le importaba menos que el ser agradable a Dios» (Fl. Josefo, Ant. Jud., I 224). No hay, pues, duda que Abraham erà «un idólatra»: S. Kierkegaard, o.c., 17. 79. Gén 17, 19-20. 80. Cf. Éx 20,2-6; 32,25-29. El Deuteronomista subrayará luego esa exigencia del único Dios: Cf. Dt 6,4-5; 13,2-19:vv.7-11. 81. Gén 22,3; Hebr 11,17. «Abrahm abandonó la razón terrestre y tomó la fe, de lo contrario no hubiera partido», pues, «se trataba de un viaje (humanamente) absurdo»: S. Kierkegaard, o.c., 24. 82. S. Kierkegaard, o.c., 31. Ya la paráfrasis targúmica precisa, que Abraham 
por esa fe caminó en silencio con su hijo durante tres terribles jornadas, hasta divisar «al tercer día... el lugar» indicado (Gén 22,4); por esa fe ordenó a sus criados quedarse en la falda del monte, hasta que él "volviese con su hijo» (sic!) tras haber «hecho adoración» (Gén 22,5); por esa fe «cargó sobre su hijo Isaac la leña del holocausto» y «se fueron los dos juntos» a la cima del Moria ${ }^{83}$; nor esa fe contestó a la pregunta de aquél por "cl cordero para el holocausto» con la respuesta propia de un creyente adulto: «iDios proveerá!» (Gén 22,7-8); por esa fe «construyó el altar y dispuso la leña» y «ató a Isaac» sobre ella (Gén 22,9). Todo eso lo hizo Abraham por su fe adulta en Dios, la cual devino «fe perfecta» cuando - igesto inaudito! - aquél «alargó la mano y tomó el cuchillo para sacrificar a su hijo» dócil ${ }^{84}$ : Un gesto sólo comprensible en el perfecto creyente, que ha transcendido y vigorizado su razón humana con la fe o total confianza en «el Dios que da la vida a los muertos y llama a lo que no es para que sea», apoyándose del todo en el poder de Quien a dos ancianos -él y Sara - sexualmente muertos dio un hijo y, por tanto, «es poderoso aún para resucitar de entre los muertos» al degollado Isaac ${ }^{85}$. ¡Una fe no deludida! Pues a Dios le bastó ese gesto sacrificial, por el que Abraham «no rehusó a su único hijo» y mostró con ello creer o apoyarse sólo en Él ${ }^{86}$. Y seguidamente proveyó a su creyente «el cordero» sacrificial «en lugar de su hijo» Isaac, a quien de ese modo recuperó Abraham, «para que fuese figura» de Cristo muerto y resucitado ${ }^{87}$. El creyente en Quien resucita de entre los muertos devino así padre y modelo de los creyentes «en Aquel que resucitó de entre los muertos a Jesús, Señor nuestro, quien fue entregado por nuestros pecados y fue resucitado para nuestra justificación» ${ }^{88}$.

cumplió la orden del Señor «con alegría»: TgPI ( $=$ «Neophyti 1») Gén 22,14. 83. Gén 22,6; Cf. $1 \mathrm{Pe} 2$ 24. El Targum precisa, que "caminaron los dos juntos con corazón perfecto» (TgPIGén Gén 22,6-8): ¡Obedeciendo a Dios! La tradición judaica posterior especifica, que tanto Abraham como Isaac rechazaron la tentación de satanás a no realizar el «loco gesto» de ese sacrificio, ciertamente «no querido por el Señor»: Cf. L. Ginsberg, The Legends of the Jews, I, Philadelphia 1906, 276s. 84. Sant 2,22; Gén 22,10. El Targum subrayó muy bien el dramatismo de esa trágica escena de fe en Dios, poniendo en boca de Isaac el ruego a su padre de «atarle bien, para que no te dé patadas y se invalide tu ofrenda», no sin precisar que, entonces, una voz celeste invitó a «venir y ver dos (personas) únicas en mi mundo: Una sacrifica y la otra es sacrificada, el que sacrifica no titubea y el sacrificado extiende su cuello»: TgPIGén 22,10 (Cf. a este respecto, R. le Daut, o.c., 153-170). Pablo conoció probablemtne esta paráfrasis targúmica (Cf. Rm 8,32; $4,25 a)$, la cual subraya en otro contexto el valor intercesor del sacrificio de Isaac: Abraham suplica a Dios que «cuando sus hijos estén en la hora de la angustia, recuerda la aqedá (=ligadura, sacrificio) de su padre Isaac y escucha la voz de sus súplicas y óyelos y líbralos de toda tribulación...» (TgPIGén 22,14); Cf.: R. Le Deaut, o.c., 163-70; S. Sabugal, Abbá..., 635, n. 363 (bibliogr.) 85. Rm 4,17.19; Hebr 11,19a. 86. Gén 22,11-12;15-16. 87. Gén 22,13; Hebr $11,19 \mathrm{~b} ; \mathrm{Cf} . \mathrm{Rm} 8,32$. Constante en la exégesis patrística es la interpretación tipológica del sacrificio de Isaac, como preanuncio del consumado por Cristo (Cf. D. Lerch, o.c., 46-119:106-112; J. Daniélou, o.c., 104-111), el «Cordero» provisto por Dios sobre el nuevo monte Moria del Gólgota: Cf. Jn 19,36; 1,29; 1Cor 5,7; 1Pe 1,18-19; Apoc 5,5-14.

88. $\operatorname{Rm} 4,17.24-25$. 
La historia de este incomparable creyente veterotestamentario, a quien «Jahveh bendijo en todo» (Gén 24,1) y «murió lleno de días» (Gén 25,7-10), muestra que Creer en Dios equivale ante todo a encontrarse con Él en la propia vida, mediante una experiencia personal de su fidelidad y poder salvífico; lo que requiere del creyente escuchar su llamada y, tras abandonar a los dioses de este mundo, obedecer a su exigencia y caminar bajo su guía, apoyándose sólo en su poder -luego manifestado en dones concretos o indiscutibles signos de credibilidad-y sacrificando todo ídolo en aras de su servicio y amor. Con análoga fe agradaron y sirvieron a Dios, sin duda, los demás creyentes del AT (Cf. Hebr 11,20-39), cuyos relatos sería prolijo evocar.

c) No podemos silenciar, sin embargo, el testimonio veterotestamentario sobre la fe de ISRAEL o el Pueblo paradigmático ${ }^{89}$, elegido por Dios «para conocerle y creer en» $E l{ }^{90}$. Sobre esto versa precisamente el relato del éxodo ${ }^{91}$, todo él redactado como una pedagogía o catequética iniciación hacia la fe de Israel «en Jahveh y en Moisés su siervo» (Éx 14,31). Ya el relato sobre la opresión de «los hijos de Israel» por el faraón egipcio ${ }^{92}$ culmina con el clamor de aquéllos a Dios, quien, acordándose «de su alianza» con los Padres, los «miró propicio» (Éx 2,23s) y mostró así ser el Dios fiel. Esta fidelidad divina realza también el relato sobre la vocación y misión de Moisés ${ }^{93}$, enviado por Dios al faraón y por Él dotado con «signos» de credibilidad ante oprimidos y opresor ${ }^{94}$, cuya eficacia sin embargo fue diversa: «El corazón del faraón se endureció», mientras que el Pueblo creyó [a Moisés] y «adoró» al Dios ${ }^{95}$ que, por fidelidad a sus promesas y alianza ${ }^{96}$, decidió librarle, «para que» le den culto ${ }^{97}$ y sepan que Él es su Dios salvador ${ }^{98}$. Esta experiencia del poder salvífico de Dios subraya el relato sobre las plagas ${ }^{99} \mathrm{o}$ los «signos y prodigios», realizados ante el faraón por el dócil «siervo de Jahveh» Moisés mediante un simple cayado ${ }^{100}$, sin que el Pueblo haga algo: Jahveh es el verdadero Autor de esas gestas liberadoras o signos propedéuticos al servicio de la fe de Israel en su Dios ${ }^{101}$. Una concepción prolongada en el relato sobre la salida de Egipto ${ }^{102}$, subrayando tanto la fidelidad de Jahveh a su promesa liberadora ${ }^{103}$ como el memorial perpetuo, que de esa gesta salvífica hará Israel tanto en las fiestas de la Pascua ${ }^{104}$ y los Ázimos ${ }^{105}$ como en el rito sobre

89. Cf. 1Cor 10,1-11. 90. Cf. Is 43,10-11. 91. Éx 1,1-15,21: Para su análisis literario y exégesis teológica, Cf. S. Sabugal, ¿Liberación y secularización?: Intento de una respuesta biblica, Madrid 1978, 56-65 (bibliogr.). 92. Éx 1,1-2,25: Cf. S. Sabugal, o.c., 51-54 (bibliogr.). 93. Éx 3,1-7,13: Cf. S. Sabugal, o.c., 54-56 (bibliogr.). 94. Éx 4,1-16; 7,1-13. 95. Éx 7,8-13; 4,30-31. El hecho de que a raíz de «las palabras de Moisés», referidas por Aarón y corroboradas con «signos» por aquél (Éx 4,30), «el Pueblo creyó y, al oír que Jahveh había visitado a los hijos de Israel y había visto su aflicción, se postraron y adoraron» (Éx 4,31), muestra que ya entonces nació la fe adorante de Israel en Dios, por medio de la Palabra confirmada con signos (Cf. Mc 16,15-18.20): Cf. M. Norh, Exodus (ATD 5), Göttingen 31965, 36; G. Auzou, De la servidumbre al servicio. Estudio del libro del Éxodo, Madrid ${ }^{4} 1974$, 98. 96. Éx 3,4-8.16.17. 97. Éx 3,$18 ; 4,23 ; 5,1$. 98. Éx 6,6-7. 99. Éx 7,14-11,10: Cf. S. Sabugal, o.c., 56-58 (bibliogr.). 100 Cf. Éx 7,9-13.17-21; 8,1-2.12-13; 9,22-25; 10,12-15. 101. Éx 10,2: Cf. S. Sabugal, o.c., 58. 102. Éx 11,1-13,16: Cf. S. Sabugal, o.c., 5860 (bibliogr.). 103. Éx 12,41a: Cf. 3,$20 ; 6,1.6 ; 7,3-5$. 104. Éx 12,34-51; Cf. 12,26s. 105. Éx 13,3-10; Cf. 12,7. 
la consagración de los primogénitos ${ }^{106}$, profesando en todas esas ocasiones $s u$ fe en Quien le liberó «con mano fuerte» de la esclavitud ${ }^{107}$. Gesta salvífica, que culmina en el relato a cerca de la definitiva victoria de Jahveh sobre el faraón ${ }^{108}$ y su ejército, al que aniquiló en el Mar Rojo «sin escapar uno solo» (Éx 14,14-29): Así «salvó aquel día» milagrosamente ${ }^{109}$ «Jahveh del poder de los egipcios a Israel», quien «vio a» éstos «muertos a la orilla del mar»y, «viendo la mano fuerte desplegada por Jahveh contra» ellos, «temió a Jahveh y creyeron en Jahveh y en Moisés su siervo" ${ }^{110}$. Sólo ahora la fe inicial (Éx 4,31) de Israel (Cf. supra) devino fe vigorizada o confianza en el poder salvador del Dios fiel, fe seguidamente proclamada por el Pueblo liberado en el coral canto de alabanza a Quien «se cubrió de gloria precipitando al mar caballos y jinetes» ${ }^{111}$. De esa fe o encuentro con el Dios fiel y salvador nació, pues, el Pueblo de la alabanza, en la que se traduce y culmina también la fe de otros muchos «creyentes» veterotestamentarios ${ }^{112}$. Es ésa, por tanto, una constante de la fe de Israel, como lo refleja su libro de oración o el Salterio, en el que su experiencia personal de Dios o su encuentro histórico con Él se tradujo en incontenidos cantos de agradecimiento ${ }^{113}$ y en sublimes himnos de alabanza ${ }^{114}$ al Dios potentemente salvador, incansablemente misericordioso y siempre fiel. Lo que significa: Creer en Dios equivale experimentar en la propia historia su fidelidad y poder salvifico sobre toda realidad de opresión, de sufrimiento y de muerte, suscitando esa experiencia la jubilosa bendición o agradecimiento e incontenida alabanza al Dios salvador, misericordioso y fiel.

Esa exultante y neófita fe de Israel, sin embargo, aún no es fe adulta, en la que la duda radical ya no haga mella. Lo muestra ya el hecho de que, a la inmediata y reiterada «prueba» en el desierto ${ }^{115}$, sucumbirá el Pueblo: Reaccionando con la «murmuración» incrédula «contra Jahveh» ${ }^{116}$, dudando de su asistencia salvadora v reprochándole (sic!) su falta de amor e. incluso, su "odio» (!) para con él "17: « ¡No creyeron en Dios ni confiaron en su salvación!» ${ }^{118}$. Por lo demás, la promesa fiel de «hacer cuanto dijo Jahveh», con

lwo. Éx 13,1-2.11-16. 107. Éx 12,17.27.51; 13,8-9.14.16. 108. Éx 13,17-15,21: Cf. S. Sabugal, o.c., 60-63 (bibliogr.). 109. Contra las pretendidas «explicaciones naturales» de esa sesta salvífica, un riguroso análisis literario del relato (Éx 14,15-31) muestra, más bien, que fue "evidentemente un milagro» sobriamente narrado: R. de Vaux, Historia, I 367-73; S. Sabugal, o.c., 62. 110. Éx 14,30-31; Esa gesta salvífica de Jahveh será luego un artículo fundamental de la fe de Israel (Dt 11,4; Jos 24,6-7a; Sal 78,13; 136,13-15): Cf. G. von Rad, Teología del $A T$, I 231; R. de Vaux, Historia, I 370. 111. Éx 15,1-21. 112. Moisés (Cf. Dt. 32,1-44), Débora y Baraq (Cf. Jces 5,1-31), David (Cf. 2Sam 22,1-51), Judit (Cf. Jdt 15,14-16,17) y Tobías (Cf. Tob 11,14-16; 12,21-14,1): Cf. S. Sabugal, Liberación..., 106-110; Id., Abbá..., 340-42 (bibliogr.). Sobre la fe de los principales creyentes del A.T., Cf.: P. Antoine, a.c., 279-82 (bibliogr.); E. Galbiati, La fede nei personaggi della Bibbia, Milano 1979, 27-127. 113. Cf. Sal 18.33-34.40.65-66. 92.116.118.138 etc. 114. Cf. Sal 8.9.29.33.46-48.84.93.96-100.103-6.113-14.135-36.145-50. 115. Cf. Éx 15,25 b; 16,$4 ; 20,20$; Dt 8,2.16; 13,4; Sab 13,9-10. 116. Éx 16,8; Núm 14,1.11; 16,11; Dt 1,27; 9,23-24; Cf. Éx 15,22-16,11; 17,3 (=Núm 20,3-4); Núm 14,2.36. 117. Éx 17,3; Dt 1,27; Cf. Éx 16,3; Núm 20,3-4; 21,5. «La incredulidad en el amor del Dios salvador... fue el primer pecado capital de Israel»: S. Sabugal, Abbá..., 577s; Id.. Pecado y reconciliación en el mensaje de Jesús, Palermo 1985, 27s. 118. Sal 78.22; Cf. Ním 14.11: Di 9.23; Sal 106,24. 
que respondió Israel a la alianza sinaítica ${ }^{119}$, será transgredida reiteradamente por aquél con la incrédula «rebeliónn» y la apóstata «idolatría» característica de «la prostituta» o «esposa infiel» de Jahveh ${ }^{120}$, por Cuya fidelidad sin embargo le dio «la tierra prometida» y cumplió «sin fallar una sola todas sus espléndidas promesas a Israel» ${ }^{121}$. En vano prometerá luego éste, creer sólo en su Dios o «servir exclusivamente a Jahveh», al renovar Josué la alianza ${ }^{122}$ : La reiterada infidelidad a esa promesa ${ }^{123}$ culminó con la petición y nombramiento de «un rey», rechazando así «el reinado de Jahveh sobre» ellos y «renegando de su Dios» ${ }^{24}$. Por su reiterada incredulidad o «desobediencia» a Jahveh fue por Él rechazado Saúl ${ }^{125}$ y sustituido por el joven «pastor» David ${ }^{126}$, cuyas gestas liberadoras realizó «consultando» a su Dios y apoyándose en el poder de Quien ${ }^{127}$, por ello, fue su «roca y baluarte», su «libertador y salvador» ${ }^{128}$, tras haberle prometido con «alianza fiel» o perpetua «afirmar su descendencia» y «consolidar su trono eternamente» ${ }^{129}$. Así lo hizo ya Dios con su hijo Salomón ${ }^{130}$, por cuya idolátrica infidelidad, sin embargo, decidió dividir su reino en dos partes ${ }^{131}$ : El de Israel desaparecerá (a. 721) por su «incredulidad en Jahveh" ${ }^{132}$, corriendo posteriormente (a. 587) análoga suerte en el de Judá ${ }^{133}$ a causa de la incredulidad a «los mensajeros de Dios» o profetas ${ }^{134}$, quienes reiteradamente le exhortaban a creer o apoyarse sólo en Él ${ }^{135}$ y amarle con la totalidad del amor ${ }^{136}$. «El Dios fiel» ${ }^{137}$, sin embargo, decidió realizar un nuevo éxodo con su Pueblo, por Él «elegido para que le conozca y crea en» su único Dios «salvador» y cuente luego «su alabanza» ${ }^{138}$, prometiendo realizar asimismo esa gesta salvífica mediante «su Siervo» ${ }^{139}$, cuya fe adulta o total confianza en Él ${ }^{140}$ debe imitar quien le tema: « Confíe en el nombre de Jahveh y apóyese en su Dios!» ${ }^{141}$. Esta fe adulta tuvo ya sin duda, a lo largo de la historia de Israel, «el resto» ${ }^{142}$ de «los fieles» ${ }^{143}$ a Jahveh o creyentes en el único Dios ${ }^{144}$, devenidos sus «servidores» ${ }^{145} \mathrm{y}$ «amigos» ${ }^{146}$ porque, en la

119. Éx 19-24: Cf. 19,8; 24,3.7. 120. Éx 32,1-6; Núm 25,1-3; Ez 20,1-26; 23,3-49; Os 1,2-3,1: Cf S. Sabugal, Abbá..., 578s; Pecado..., 28s. 121. Jos 21,43-45; 23,14. 122. Jos 24,1-28: Cf. vv. 16-18.21.24. 123. Cf. Jces 2,11-13.17.19-20; 3,5-7.12; 4,1; 6,1; 8,33-34; 10,6; 13,1. 124. 1Sam 8-12: Cf. 8,$7 ; 10,18-19 ; 12,12.17-19$. 125. Cf. 1Sam 13,7-14; 15,9-35. 126. 1Sam 16,1-13. 127. Cf. 1Sam 17,40-54; 2Sam 5,17-25. 128. 2Sam 22,1-51. 129. 2Sam 7,12-16; Sal 89,29. 130. 1Re 3-10: Cf. $3,5-14 ; 4,9.18 ; 8,15-21.56 ; 9,3-6 ; 10,9$. 131. $1 \operatorname{Re} 11,1-13.26-39$; Cf. 12,1-33. 132. Cf. $2 \operatorname{Re} 17,5-23: v v .13-14$ 133. $2 \operatorname{Re} 23,36-25,21$ $=2$ Crón 36,5-21. 134. 2 Crón 36,15-16. 135. Cf. 1 Re 18,21; Is 7,9; 26,4; 2Crón 20,20. 136. Cf. Dt $6,4-5 ; 10,15-21$; Os 6,6 . 137. Is 49,7 ; Neh 9,33 . 138. Is $43,10-11.16-21 ; 51,3$. 139. Cf. Is $42,1-9 ; 49,1-6 ; 50,4-9 ; 52,13-53,12$. 140. Cf. Is $50,5-9$. 141. Is 50,10 . 142. Is $4,2-3 ; 6,13 ; 7,3 ; 10,19-21 ; 28,5-6 ; 37,4.31-32$; Cf. Am 3,12; 5,15; 9,8-10; Miq 4,7; 5,2; Sof 2,7-9; 3,12; Jer 3,14; 5,18; Ez 5,3. A este respecto, Cf.: R. de Vaux, Le «Reste d'Israël» d'après les Prophètes, en: RB 42 (1933) 526-39; S. Garofalo, La nozione profetica del «resto d'Israele», Roma 1942; F. Dreyfus, La doctrine du reste d'Israël chez le prophète Isaïe: RSPhTh 39 (1955) 361-86; U. Stegemann, Der Restgedanke bei Jesaias: BZ 13 (1969) 161-86; G. von Rad, Teología del AT, II 37-39.207s; W.E. Müller, Die Vorstellung vom Rest im $A T$, Neukirchen-Vluyn 21973 , 48-95. 143. Sal 31,$24 ; 101,6$. 144. Cf. 1 Re 18,$39 ; 19,18$. 145. Sal 101,6 . 146. Sal 31,24 . 
opresión y adversidad, confiaron o esperaron en Él ${ }^{147}$ y en su poder se apoyaron ${ }^{148}$, como lo hizo el Pueblo rescatado del exilio babilónico, acertada y bellamente descrito en la imagen de la Esposa, «que sube del desierto apoyada en su Amado» ${ }^{149}$ : „Eso es la fe!

Creer en Dios, según el vocabulario veterotestamentario y el testimonio de sus creyentes, equivale por tanto a un encuentro personal con Él o una experiencia de su misericordia y poder salvífico sobre toda realidad de esclavitud, de sufrimiento y de muerte; lo que supone no sólo haber escuchado su llamada y dado total crédito a su palabra, -comunicada por revelación personal o mediante sus mensajeros-, sino también tomar en serio su promesa salvífica y caminar sólo bajo su guía, dispuesto a dejar la servidumbre a los ídolos de este mundo y a sacrificar incluso el propio «Isaac» en aras de su servicio exclusivo y amor total, para confiarse sin reservas a Él y apoyar por completo en su poder la propia historia, vivida en un espiritu de jubiloso agradecimiento e incontenida bendición o alabanza al Dios potentemente salvador, incansablemente misericordioso y siempre fiel.

2. Esa concepción veterotestamentaria de la fe se prolonga y culmina en el NuEvo TESTAMENTO ${ }^{150}$, cuyos documentos nos han trasmitido el respectivo testimonio del «Israel de Dios» ${ }^{151}$ o de quienes, en calidad de verdadera «descendencia»y auténticos «hijos» del «creyente Abraham» ${ }^{152}$, son sencillamente «los creyentes» (Cf. infra).

1) Entre éstos sobresale MARÍA ${ }^{153}$, «la creyente» (Lc 1,45$)$ por excelencia, con ese título mariano designada por san Lucas $-\mathrm{y}$ venerada sin duda por

147. Cf. Sal $37,3-9 ; 38,12-16$; Is 30,$18 ; 33,2$. 148. Cf. Is 10,20 . 149. Cant 8,5 ; Cf. 8,3.6. 150. Además de los artículos generales (P. Antoine, DBS III 291-305.308-10; R. Bultmann, ThWNT III 203-30; J. Duplacy, Cath. IV 1373-78; H. Braun, RGG II 1590-97; R. Schnackenburg, LThK IV 915-17; E.C. Blackman, IDB II 223-24.229-34; W. Bauer, WörterbuchNT, 1309-19; H. Zimmermann, DTB 391-404; J-Dupont, VTB 331-35; M. Seckler, CFT I 56367; D. Lürmann, RAC XI 64-69; G. Barth, EWNT III 216-33), Cf.: A Schlatter, o.c., 98-539.586612; AA.VV., LumVie 22 (1955) 45-107 [ = Ev. sinópt., Ep. paul., Jn]; G. Ebeling, Das Wesen des christlichen Glaubens, Tübingen 1959 (passim); M. Meinertz, Teología del NT, Madrid 21966, 9496.262-4.393-411; R. Schnackenburg, El testimonio moral del NT, Madrid 1965, 25-32.287-91; K.G. Kümmel, Die Theologie des NT, Göttingen 1969, 85-121; J. Pfammatter, La fe según la S. Escritura, B. El NT: MS I.2, 885-904; C. Spicq, Théologie morale du NT, I, Paris ${ }^{4} 1970,228-77$; H. Urs von Balthasar, Saggi Teologici, III, Brescia 1972, 49-87; Id., Gloria, I, Milano 1975, 117-392; J. Jeremías, Teología del NT, Salamanca 1974, 181-98; K.H. Schelkle, Teología del NT, II, Barcelona 1976, 383-93; L. Goppelt, Theologie des NT, II, Göttingen 1976, 154-164; D. Lührmann, Glauben im frühen Christentum, Gütersloh 1976; J.M. Faux, La foi du Nouveau Testament, Bruxelles 1977. 151. Gál 6,10; Cf. Rm 9,6-8; 1Cor 10,18 . 152. Gál 3,7-9.29; Rm 3,11-12.17. 153. Cf.: R. Garrigou-Lagrange, La Madre del Salvador, Madrid 21979, 152-55; R. Guardini, La Madre del Señor, Madrid 1965, 39-84; J. Galot, Maria, tipo e modello della Chiesa: «La Chiesa del Vaticano II» (ed. G. Baraúna), Roma 1965, 1156-71:1166-68; M. Thurian, María, Madre del Señor, figura de la Iglesia, Zaragoza 1966, 83-96; O. da Spinetoli, Maria nella tradizione biblica, Bologna 1967, 109-38; H. Urs von Balthasar, Gloria, I 311-15; E. Galbiati, o.c., 123-36; A. Feuillet, Jésus et sa Mère, Paris 1978, 120-21.130-34; J. Galot, Riflessioni sul primo atto di fede cristiana: Maria, la prima credente: CivCatt 129 (1978) 27-39; Id., Maria, la donna nell'opera di salvezza, Roma 1984, 50-72; J. Alfaro, Maria, la bienaventurada porque ha creído, Roma 1982, espec. 3343; B. Häring, María prototipo de la fe, Barcelona 1983, 37-40. 
su comunidad cristiana - quien fue la primera creyente neotestamentaria. Eso fue ya desde el principio ${ }^{154}$ : Respondiendo al mensaje celeste de su elección como Madre del prometido Mesías davídico ${ }^{155}$ con un consciente y libre ${ }^{156}$, rendido, confiado y obediente «hágase en mí»" ${ }^{157}$, la "Virgen» de Nazaret no sólo dio total crédito a la promesa divina sino también asintió por completo a la acción del «Espíritu Santo» en ella y se apoyó sin reservas en «el poder del Altísimo», para quien «nada es imposible» ${ }^{158}$. ¿En eso consistió su fe! Ésta fue, por tanto, el incondicional «amén» de María al misterio de la Encarnación y de la maternidad del Mesías, siendo por ello saludada como «la más bendita entre las mujeres» y proclamada «bienaventurada por todas las generaciones» ${ }^{159}$. Por esa fe, la encinta del mesiánico Siervo de Dios no se resistió - como éste- al mal (Cf. Is 50,5-6) de pasar ante «su esposo José» por una adúltera ${ }^{160}$, confiando - como aquél- en el Dios que «habría de ayudarla para no ser insultada» (Is 50,7 ) y, a su tiempo, manifestaría la verdad, lo que seguidamente hizo ${ }^{161}$ : ¡Así superó esta primera prueba la fe de María! Una fe, por lo demás, «prontamente» traducida en humilde servicio ${ }^{162}$, manifestada luego en la fidelidad a «la Ley del Señor» ${ }^{163}$ y atenta siempre no sólo a escuchar interiormente sino también a comprender la Voz divina en los eventos de su historia ${ }^{164}$ : ¡María la creyente! Por su fe en Jesús aceleró sin duda la Madre el primer «signo» mesiánico de su Hijo y, con ello, colaboró a suscitar «la fe en Él» de «sus discípulos» ${ }^{165}$, con quienes caminó luego - como insuperable

154. Cf. Lc 1,26-38. 155. Lc 1,28-33. 156. (f. Lc 1,34. Con el interrogante: «¿Cómo puede ser esto, puesto que no conozco varón?», María no rehúsa creer-como lo hizo Zacarías (Lc 1,18-20) - sino pide una explicación de "cómo puede ser» madre del Mesías quien [= ella] es sólo "prometida» (Lc 1,27) no aún formal esposa de José ni dispuesta, por tanto, a tener con él relaciones matrimoniales para el inmediato futuro espresado por la promesa angélica (así con $\mathrm{H}$. Schürmann, Das Lukasevangelium, I, Freiburg 1969, 50; Cf. también J. Schmid, El Evangelio de san Lucas, Barcelona 1968, 62s). Su pregunta formula, pues, una dificultad real, - seguidamente superada por el Mensajero celeste (Cf. Lc 1,35-37)-, antes de pronunciar el consciente y libre «fiat» de su fe «al cumplimiento de lo que de parte del Señor se le dijo» (Lc 1,38.45). Hay que subrayar, por tanto, «la libertad y el mérito de ese sí», por el que María «se entregó con un abandono generoso a las exigencias... de la obra, que Dios comenzaba en ella»: P. Benoit, L'annonciation: «Exégèse et Théologie», III, Paris 1968, 197-205:208s; Cf. también A. Feuillet, o.c., 121. 157. Lc 1,38a. Esa respuesta de María, anticipando con su creyente «hágase» el creyente «hágase» getsemaníaco de Jesús (Lc 22,42par), expresa su «fe» como «un acto de ofrenda» y «de obediencia» y «de confianza» en Dios: M. Thurian, o.c., 90. 158. Lc 1,35-37. Con su creyente «fiat» a la acción en ella del Dios, a quien «nada es imposible» (v. 37), superó María la incredulidad de Abraham y de Sara (Gén 17,17; 18,12-13: Cf. supra, 129) ante la promesa de «un hijo» por Jahveh, para quien «nada es imposible» (Gén 18,14), jugando así «la fe de María un papel más grande aún [que la de Abraham] en la historia de la salvación»: A. Feuillet, o.c., 120. Sólo subraya el paralelismo ( $n o$ la superioridad!) entre la fe de Abraham y de Maria M. Thurian, o.c., 9294. 159. Lc $1,42.48$ 160. Cf. Mt 1,18b-20a. 161. Cf. Mt 1,20b-23. 162. Cf. Lc 1,39 40.56: ¡Encinta du «Siervo de Dıos» (ası es presentado Jesús en Lc 1-2: Cf. S. Sabugal, Christos, Barcelona 1972, 72-75), María sirve a su pi ima Isabel! 163. Cf. Lc 2,22-24.27. 164. Cf. Lc 2,19.49-51. 165. Cf. Jn 2,1-11. San Juan describe en esa ocasión «la actitud de María comn la 
modelo suyo y de todos los creyentes - no sólo escuchando y conservando «la Palabra de Dios» ${ }^{166}$ sino también aprendiendo a «cumplir» su voluntad ${ }^{167}$. Así avanzó María «en la peregrinación de la fe» ${ }^{168}$ adulta: Aquella que, en la prueba final, la mantuvo «en pie junto a la Cruz» ${ }^{169}$, ofreciendo con su consentimiento sin duda - como Abraham - sobre el Moria del Gólgota el sacrificio del nuevo Isaac, su Hijo, a quien - como aquél- «lo recobró» ${ }^{170}$ resucitado. Creer en Dios significa, pues, aceptar con un consciente y libre «fiat»la Palabra de su mensajero y, conservándola activamente "en el corazón», caminar por la senda de su voluntad con Jesús, abrazando la propia cruz y viendo ésta glorificada por la potencia de su resurrección. Así creyó María y, por ello, devino la Madre de los creyentes neotestamentarios así como «tipo de la Iglesia en orden de la fe» ${ }^{171} \mathrm{o}$ insuperable modelo de todos aquéllos.

2) Con la sola excepción del creyente JESÚS DE NAZARET ${ }^{172}$. Es cierto que los autores neotestamentarios nunca dicen expresamente que creyó Quien, para ellos, es más bien objeto personal de la fe (Cf. infra): Sí lo insinúan, sin embargo, clara y reiteradamente. Nada de extraño, por otra parte. Pues el Hijo de Dios, «encarnado» por concepción virginal «en el seno» de María y de ella «nacido según la carne» ${ }^{173}$, es «el hombre Cristo Jesús» ${ }^{174}$, asemejado «en todo a» nosotros y, como nosotros, «también envuelto en flaqueza» ${ }^{175 .}$ El «Dios verdadero» devenido «verdadero hombre» caminó, pues, sin duda - como todo hombre- «en la fe» ${ }^{176}$, propia por lo demás de quien «crecía en... gracia ante Dios» y, en su asumida «condición de siervo», fue «obedien-

plenitud de una fe, que cree en Jesús antes de que Él haga su primer milagro», no -como «ios apóstoles y todas las demás personas» que le seguían - «después de haber experimentado su poder sobrehumano»: J. Alfaro, o.c., 36. 166. Cf. Lc 11,27-28 = 2,19.51. Ese paradigmatismo cristiano de la fe de María es subrayado sobre todo por san Lucas: «Conservando y meditando en su corazón» el significado de «las cosas» o eventos con que Dios le hablaba (Lc 2,19.51), yaquélla es consumado paradigma de los creyentes que «conservan la Palabra escuchada en un corazón bueno y recto, fructificándola con perseverancia» $(\operatorname{Lc} 8,15)$. Sólo éstos son los verdaderos creyentes cristianos, que han tenido, tienen y tendrán su acabado modelo de fe en «la creyente» María (Lc 1,45). 167. Cf. Mc 3,31-35; a este respecto, Cf. M.-J. Lagrange, Evangile selon saint Marc, Paris 1966, 77s. 168. Conc. Vat. II, Const. LG 58. María, en efecto, «vivió en la tierra en un claroscuro perpetuo»: R. Garrigou-Lagrange, o.c., 153. 169. Jn 19,25a. 170. Hebr 11,19b; Cf. Gén 22,11-19: supra, 131. «Sufriendo con» Jesús «y asociándose... a su sacrificio», María «cooperó en forma enteramente impar a la obra del Salvador». (Conc. Vat. II, Const. LG 58.61), haciéndolo, por lo demás, «con fe y obediencia libres», para -en expresión de san Ireneo- desatar con su obediencia fiel lo que la desobediencia incrédula de Eva había ligado: $I b$., 56. 171. Conc. Vat. II, Const. LG 63. 172. Cf. a este respecto: E. Fuchs, Jesus un der Glaube: «Zur Frage nach dem historischen Jesus», Tübingen 21965, 238-57:252ss [ = ZThK 1958, 107-85]; G. Ebeling, o.c., 48-65; H. Urs von Balthasar, Fides Christi: «Ensayos Teológicos», II 57-96:66-79; Id., Saggi Teologici, III 51-57; Id., Gloria, I 175-76.301-3; VII, Milano 1975, 127; R. Pesch, Der Glaube Jesus: Christ in der Gegenwart 24 (1972) 221-22; W. Thüsing, Jesús como el «creyente»: K. Rahner-W-Thüsing, Cristología. Estudio teológico y exegético (trad. españ.), Madrid 1975, 211-26; K. Rahner, Nachfolge des Gekreuzigten: «Schriften zur Theologie», XIII, Freiburg 1978, 188-203: 197s; J. Guillet, la foi de Jésus, Paris 1980; F. Sebastián, a.c., (supra: 123), 15-17. 173. Jn 1,14; Lc 1,31-38; Mt 1,18-25; Rm 1,3; Gál 4,4. 174. 1Tim 2,5; Cf. Jn 9,11 etc. Así lo subraya el NT, y sobre todo Jn: Cf. S. Sabugal, Christós, Barcelona 1972, 409-11. 175. Hebr 2,$17 ; 5,2$. 176. 2Cor 5,7; Cf. 1 Cor 12,12. 
te hasta la muerte... de cruz» ${ }^{177}$. Esa fe del pre-anunciado «Siervo de Jahveh» mesiánico se refleja efectivamente en la ilimitada confianza y fiel sumisión de Jesús a la voluntad del Padre, a lo largo de toda su vida ${ }^{178}$. Ya desde el principio. Es lo que trasluce su inicial victoria sobre «el tentador» diabólico, mediante quien «el Espíritu» (sic!) probó en «el desierto» su obediencia al Padre o su fidelidad ${ }^{179}$ a cumplir la previamente recibida vocación mesiánica del Siervo ${ }^{180}$ : Quien «fue probado en todo igual que nosotros, excepto en el pecado» ${ }^{181}$, superó en «el desierto» la prueba de la fe, a la que en «el desierto» sucumbió Israel ${ }^{182}$, no dudando en esa ocasión del amor del Padre y sí apoyándose o confiando totalmente en Él. Esto refleja también su asídua oración al Padre ${ }^{183}$, practicada sin duda con la fe o filial confianza en quien «siempre le escuchó» ${ }^{184} \mathrm{y}$, por ello, pudo exhortar a sus discípulos: «Todo cuanto pidáis en la oración, creed que ya lo habéis recibido y lo obtendréis» ${ }^{185}$. Como Él consiguió por su fe la sequedad de la higuera maldecida ${ }^{186}$ y la curación de un niño epiléptico, realizada ésta en la convicción de que «todo es posible a quien cree» ${ }^{187}$. Por la sencilla razón de que el creyente se apoya en el poder de Dios, para quien «todo es posible» ${ }^{188}$, participando por tanto de su omnipotencia: De ésta participó Jesús por su fe. Y en la fe vivió asimismo de cara al futuro ${ }^{189}$ quien, aunque consciente de ser el Hijo natural de Dios y haberle sido «entregado por el Padre toda» revelación y poder ${ }^{190}, \sin$ embargo «creció en sabiduría... ante Dios y ante los hombres» (Lc 2,52), teniendo por tanto su conocimiento las limitaciones propias de quien «camina

177. Lc 1,52 ; Fil 2,7-8. 178. Cf. Jn 8,$29 ; 4,34 ; 6,27$; Lc 2,49 . Sobre la fe del «Siervo de Jahveh», Cf. supra, 134. 179. Cf. Mt 4,1-11 par. 180. Mc 1,10-11par. Esa vocación mesiánica del «Siervo de Dios» recibió Jesús en el bautismo: Cf. J. Jeremías, Teología NT, 67-73; S. Sabugal, Christós, 163-67. 181. Hebr 5,2; Cf. Lc 22,28. Sobre las tentaciones de Jesús, Cf. S. Sabugal, Abbá..., 720s. 182. Cf. supra, 133; H. P. Thompson, Called-Proved-Obedient. A study in the baptism and temptation narratives of Matthew and Luke: JThSt 11 (1960) 1-12; $\mathrm{H}$. Riesenfeld, Le caractère messianique de la tentation au désert: «La venue du Messie», Bruges 1962, 51-63; J. Dupont, Les tentations de Jésus au désert, Bruges 1968; J. Jeremías, o.c., 88-96; Ch. H. Dodd, El Fundador del Cristianismo, Barcelona 1974, 146; S. Sabugal, Liberación..., 199.202; Id., Abbá..., 215.721. 183. Cf. a este respecto: J. Jeremías, o.c., 83.220-25; Id., Abba, Salamanca 1981, 62-70.81-86; S. Sabugal, Abbá..., 339-50 (bibliogr.). $\quad$ 184. Jn 11,42. Cf. a este respecto J. Guillet, o.c., 65-77: Puesto que «la oración es imposible sin la fe», la plegaria asídua de Jesús fue sin duda «la oración auténtica en la few (65.67). Así también W. Thüsing, o.c., 213s. 185. Mc $11,24=$ Mt 21,23. 186. Mc 11,20-22 (=Mt 21,20-21). Así con: J.M. Faux, o.c., 147; R. Pesch, Das Markusevangelium, II (HerdersThKN II.2), Freiburg 1977,204; J. Gnilka, Das Evangelium nach Markus (EKK II.2), Neukirchen-Vluyn 1979, $34 . \quad$ 187. Mc 9,14-29: Al nivel primitivo de la tradición evangélica, ese «creyente a quien todo es posible» (v. 23) no es «el padre del niño» (v. 24), -como lo interpretó ciertamente el evangelista Marcos (Cf. 11,2224)-, sino Jesús, Quien realizando seguidamente el prodigio (vv. 25-27) mostró tener el poder, solicitado por aquél (v. 22b) y reservado sin limitación - «todo es posible»- alguna «a quien cree» (v. 23). Así con: W. Grundmann, Das Evangelium nach Markus, Berlin 21968, 190; W. Thüsing, o.c., 213; R. Pesch, o.c., II 92s; J. Gnilka, o.c., II 48. Más cautos: J. Jeremías, Teología $N T$, 197s; J. Guillet, o.c., 127s. 188. Mc 10,27par. 190. Mt 11,27 (=Lc 10,22): Cf. S. Sabugal, Abbá..., 395-97.

189. Cf. Guillet, o.c., 97-114. 
en la fe, no en la visión» ${ }^{191}$ : Interrogó por ello a los hombres y esperó su respuesta ${ }^{192}$, se admiró de su inesperada reacción ${ }^{193} \ldots$, ¡descubriendo siempre lo que aún le estaba velado! También Él, pues, conoció «ahora de un modo imperfecto»y, como «en un espejo», vio «borrosamente el futuro» ${ }^{194}$, ignorando totalmente incluso «el día y la hora» del fin del mundo: ¡Lo sabe «sólo el Padre»! ${ }^{195}$ Y a éste se abandonó el creyente Jesús en la prueba definitiva de su fe, al llegar «la hora» de la cruz ${ }^{196}$ : Así lo refleja su confiada plegaria no sólo en Getsemaní, sometiendo al Padre su querer ${ }^{197}$, sino también en la cruz, dirigiéndole la confiada súplica del justo, que experimentó el «abandono de Dios» pero confió en su salvación final ${ }^{198} \mathrm{y}$, por eso, le entregó «el espíritu» ${ }^{199}$. ¿Así mueren los verdaderos creyentes! ¿Así murió también el creyente Jesús! Y sabemos que su fe o total confianza en el Padre no quedó defraudada: Le «resucitó al tercer día» de entre los muertos: como «Espíritu vivificante» y «le exaltó a su derecha», constituyéndole «único Señor y Salvador» para cuantos «invocan su nombre» ${ }^{200}$. Desde el principio hasta el final vivió, pues, el encarnado Hijo natural de Dios en la fe propia de su progresiva experiencia del Padre, sometiéndose fielmente a su voluntad, apoyándose por completo en su poder salvífico y confiándose sin reservas a su amor. Así devino Jesús «el iniciador y perfeccionador de la fe» veterotestamentaria y cristiana ${ }^{201}$ : El creyente por excelencia y el insuperable e insustituible modelo de todos los creyentes.

3) También -y sobre todo-, por tanto, de los primeros CREYENTES CRISTIANOS, de cuya fe nos informan los escritos neotestamentarios:

a) Ya durante su actividad mesiánica exigió Jesús a todos la fe o confian-

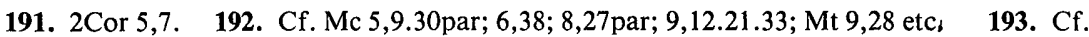
Mc 6,6; Mt 8,10par; 15,24 etc. 194. 1Cor 13,12. 195. Mc 13,32 (=Mt 24,36). La autenticidad de ese «logion», - - escandaloso ya para los primeros cristianos, como lo refleja su omisión por el paralelo de Lucas (así también en Act 1,7)—, es indiscutible: Cf. S. Sabugal, $A b b a ́$..., 390, n. 88 (bibliogr.). 196. Jn 12,23-24. 197. Mc 14,36par. Puede afirmarse que el inicial «hágase» fiel de María (Lc 1,38a) culminó en este final «hágase» creyente de Jesús. En efecto, por su forma y contenido es ésa una oración, que «supone la fe» de Jesús en el Padre: J. Guillet, o.c., 149.198. Mc 15,34 (=Mt 27,46): Cf. J. Guillet, o.c., 94.150-54. En esa ocasión, probablemente «Jesús recitó todo el salmo» 22 (J. Jeremías, Teología NT, 223), encabezado por el grito del justo abandonado por Dios (vv. 2-3), quien salvó a «los padres» de Israel (vv. 4-6) y puede salvarle de quienes le persiguen y atormentan (vv. 7-19), culminando y concluyendo su plegaria, sin embargo, con la alabanza a Dios (vv. 23-32) propia de quien confió ser escuchado por Él (v. 25) y «vivir para Él» (v. 30b). Esa oración de Jesús fue, pues, «un grito de confianza total» o «lanzado en la fe, el grito de una muerte en la fe»: J. Guillet, o.c., 94 . 199. Lc 23,46= Sal 31,6: También este salmo es la plegaria del justo probado, que «se cobija en Dios» (vv. 2-4) y le «entrega su vida» (v. 6), confiando en $E ́ l$ (v. 15) y cantando su «gran bondad» para «cuantos le temen» y «a Él se acojen» (v. 20). 200. Act 2,32-36; 4,10-12; 1 Cor 15,$45 ; \mathrm{Rm} \mathrm{10,12s.} \mathrm{201.} \mathrm{Hebr} \mathrm{12,2.} \mathrm{La} \mathrm{«tan} \mathrm{gran} \mathrm{nube} \mathrm{de} \mathrm{testi-}$ gos» veterotestamentarios sobre «la fe»» (Hebr 11,2-12,1) culmina en Jesús, «perfeccionador de la fe» veterotestamentaria e «iniciador» de la fe cristiana; $C f$. a este respecto: G. Delling, ThWNT I 486; H. Urs von Balthasar, Ensayos Teológicos, Il 70s; W. Thüsing, o.c., 212s («Jesús, a semejanza de los «antiguos», también ha creído»: 213); J. Guillet, o.c., 33-47: 43ss. 
$z a$ en su poder salvífico, para ayudar a los necesitados ${ }^{202}$. También requirió, a los por Él llamados a seguirle y dedicarse a la causa del Reino, la fe implícita en la renuncia total a las seguridades y lazos humanos, para abandonarse por completo a Él y a la providencia del Padre ${ }^{203}$. Jesús exigió, por tanto, no sólo la «fe en Dios» ${ }^{204}$ sino también en Él mismo: En el poder salvífico (Cf. supra) propio de su dignidad mesiánica y filiación divina ${ }^{205}$. La por Él congregada Comunidad mesiánica del nuevo Israel ${ }^{206}$ cobró, pues, forma en esa fe $o$ «adhesión personal a Jesús mismo» ${ }^{207}$. Una fe tambaleada ciertamente por el «escándalo» de la cruz ${ }^{208}$, renaciendo vigorosa sin embargo con el triunfo del Resucitado ${ }^{209}$.

b) A raíz de su resurrección, en efecto, se formó la Comunidad pascual de «los fieles» ${ }^{210}$, integrada por quienes, creyendo que existe «un solo Dios y Padre» así como «un solo Señor» Jesucristo y «un solo Espíritu», profesan «una sola fe» ${ }^{211}$. Recibida ésta como gratuito don de Dios ${ }^{212}$, mediante la $v i$ sión de «signos» salvadores ${ }^{212 a}$ y, sobre todo, mediante «la obediencia de la fe» ${ }^{213}$ o la sumisa audición de la Palabra ${ }^{214}$ regeneradora o vivificante y salvadora ${ }^{215}$, corroborada con «signos» ${ }^{216}$. Pues esa Palabra anuncia el amor gratuito de Dios Padre a los pecadores, manifestado no sólo en la muerte expiatoria de su Hijo Jesucristo sino también en su victoriosa resurrección y exaltación celeste como Señor de toda realidad de sufrimiento y de muerte, así constituido para hacer partícipes de su victoria a cuantos, convirtiéndose y recibiendo el liberador y vivificante don del Espíritu Santo, - amor personal de

202 Mc 2,5par; 5,34par; 6,5-6 (=Mt 13,58); 9,22-24; 10,51-52par; Mt 8,10-13 (= Lc 7,9-10); 9,28-30; 15,28 (= Mc 7,29); Jn 11,40; Lc 17,14. A este respecto, Cf.: J. Jeremías, Teología NT, 19395; G. Bornkamm, Jesús de Nazaret, Salamanca 1975, 135-39; F. Mussner, Los milagros de Jesús, Estella 1970, 54-56; X. Léon-Dufour (ed.), Los milagros de Jesús, Madrid 1979, 304-7: Todos los Evangelistas subrayan esa fe exigida por Jesús en sus milagros (Mt: S. Legasse, $I \bar{I} b$., 230-36; Lc: A. George, $I b ., 248-51)$ 203. Mc 1,16-20par; 2,13-14par; 10,28-30par; Lc 9,57-62; 12,22-31 (=Mt 6,25-34); 14,26-27 (=Mt 10,37-39); Mt 10,9-10.28-31. A este respecto, Cf.: M. Hengel, Nachfolge und Charisma (BZNW 34), Berlin 1968, 68-98; J. Jeremías, Teología NT, 195-96.258-61. 204. Mc 11,22-24=Mt 21,21-22. 205. Mc 8,27-30par; 12,35-37par; 14,61-62par; Jn 4,25-26; 10,24-25; 11,25-27. A este respecto, Cf. S. Sabugal, Christós, 85ss; Id., La embajada mesiánica de Juan Bautista, Madrid 1980, 170-91. 206. Cf. S. Sabugal, .Abbá..., 486-492:489, n. 194 (bibliogr.). 207. Ch. H. Dodd, o.c., 119, Cf. G.E. Ladd, Jesus and the Kingdom, London 1966, 242-57:245s. Aquélla fue, pues, ya «la Comunidad de fe» en Jesús: R. Schnackenburg, Reino y Reinado de Dios, Madrid ${ }^{3} 1974,200$. 208. Cf. Mc 14,27.50par. 209. Cf. Mc 16,1-14par; Lc 24,13-35; Jn 20,1-29. 210. Así son designados los primeros cristianos: Act 2,44; 4,32; 5,14; 22,19; 1Tes 1,7; 2,10.13; 2Tes 1,10; Gál 3,22; 1Cor 1,21; 14,22; Ef 1,19; 1Pe 2,7; Mc 16,17 etc. 211. Ef 4,3-6; Cf. 1 Cor 8,6 212. Ef 2,8; Fil 1,29; Cf. Jn 6,37.39.44; 10,29; 17,9.26; 2Tes 3,2. Don de Dios, obtenido por la oración, es asimismo la conservación y el aumento de la fe (Cf. infra, nn. 244.246) así como su perfección: Cf. infra, n. 251. 213. Rm 1,5; 16,26; Cf. Act 6,7; 2Tes 1,8; Rm 10,16; Jn 3,36. 214. Rm 10,8.14-17; Gál 3,2-5; Lc 8,12-13; Jn 17,20; Cf. Act 4,4; 6,7; 13,4448; 14,2 etc; 1 Tes 1,$8 ; 1$ Cor 1,$21 ; 2,4-5 ; 15,1-11$; Ef 1,$13 ;$ Col 1,23; Hebr 4,2; Jn 4,41. 215. $1 \mathrm{Pe}$ 1,23; Sant 1,18; Hebr 4,12; Jn 6,63; Act 13,26. 216. Cf. Act 13,6-12; 1Cor 2,4-5; Gál 3,2-5; Mc 1617.18 ?n: In $9.4 \mathrm{ss} ; 11,25 \mathrm{ss}$. 
Dios-, pasan de la muerte a la vida y viven no sólo amándose en la dimensión de la Cruz (Jn 13,34) sino también amando al enemigo (Mt 5,44), como testigos ante los hombres y en el mundo del «Dios-es-Amor». Este kérygma o mensaje salvador proclaman «los servidores de la Palabra» $($ Lc 1,3) o enviados del Señor como «la Buena Noticia» ${ }^{217}$ o el compendio de «la fe» ${ }^{218}$, por la que «hay que luchar» ${ }^{219}$. Quienes conservan la Palabra escuchada en «un corazón bueno y sencillo» (Lc 8,15$)$ inician el camino de la fe (Cf. infra), asintiendo o dando total crédito a Dios ${ }^{220}$, a Jesús ${ }^{221}$ y a sus mensajeros ${ }^{222}$, no sólo creyendo que «Dios existe» y es remunerador (Hebr 11,6) sino también que Jesús es «el Mesías» y «el Hijo (natural) de Dios» ${ }^{223}$ o su mesiánico «Enviado» ${ }^{224}$, y que Él «murió y resucitó» como «la (personificada) Resurrección y la Vida» o Señor de toda muerte ${ }^{225}$. La fe cristiana es, pues, un asentimiento personal al Dios que nos amó y a su enviado Hijo Jesucristo como Señor de nuestra muerte, dado aquél mediante la total credibilidad al anuncio de salvación. ¡Un asentimiento no ciego ni etéreo! Pues quien lo ha prestado cree o se apoya en un fundamento sólido, rocoso: «En quien resucitó de entre los muertos a Cristo, Señor nuestro», tras haberlo «entregado por nuestros pecados» ${ }^{226}$, apoyándose aquél asimismo «en Cristo Jesús» ${ }^{227}$ o «el Señor» ${ }^{228}$ resucitado y puesto por Dios - en la nueva Sión de la Iglesia- como «la Piedra» salvadora: ¡No será confündido quien (se apoye o) crea en Él!» ${ }^{229}$. Creyente cristiano es, pues, quien ha cimentado su vida sobre el sólido fundamento del experimentado amor y poder salvífico de Dios, así como sobre la roca del Señor resucitado y como tal experimentado en su victoria sobre toda realidad de muerte. Sobre ese sólido apoyo vive el cristiano, cuya fe culmina, por lo demás, en la total autodonación a Dios ${ }^{230}$ y a su enviado

217. Act 5,$42 ; 8,4.12 .35 .40 ; 10,36 ; 15,7.35$ etc; $1 \mathrm{Pe} 1,25 ; \mathrm{Col} 1,5 ; \mathrm{Mc} 1,15$ etc. 218. Ese significado envuelve «la fe» [ = fides quae creditur] en: Gál 1,23; 6,10; Ef 4,5; Fil 1,27 («la fe del Evangelio»); Act 6,7; 13,8; Cf. 1Tim 1,19; 2,7; 4,1.6;5,8.12;6,21; Tit 1,9; Apoc 2,13. 219. Fil 1,27; 1 Tim 1,18-19; Jds 3 . 220. Act 27,$25 ;$ Jn 5,$24 ;$ Tit 3,8 . 221. Act 5,$14 ; 18,18 ;$ Jn 4,$21 ; 6,29$; 8,31; 14,10; 1Jn 3,23; Cf. Jn 5,38; a sus «obras»: Jn 10,38. 222. Act 8,12; Cf. 2Tes 2,12; Jn 4,50; también «a las Escrituras» (Act 24,14; 26,27; Cf. Jn 5,46-47) y «a Juan Bautista» (Mc 11,31par). Ese "crédito total» prestado por la fe a Dios, a Jesús, a su Precursor y a las Escrituras no es sólo intelectual sino personal o de toda la persona del creyente, siendo en este sentido la fe «pensar con el asentimiento" (San Agustín, Sobre la predestinación de los santos, II 5; Cf. Sto. Tomás A., Sum. Theol., II-II 2, 1). Pero es erróneo afirmar, que «es preciso poner nuestra fe en el sentimiento» solamente, y definir aquélla como «Dios sensible al corazón, no a la razón»: B. Pascal, Pensées, 470.481. 223. Mt 16,16; Jn $1,34.49 ; 11,27 ; 20,31 ; 1$ Jn $5,1.5$; Cf. Jn 6,$69 ; 8,24 ; 13,19 ; 14,10-11$. 224. Jn 11,42; 16,27.30; 17,8.21. 225. 1 Tes 4,14; Rm 10,9b; Jn 11,25-27. 226. Rm 4,24-24; Cf. Col 2,12; 2 Cor 1,9; Hebr 6,1. 227. Gál 3,26; Ef 1,1; Col 1,4; 1Tim 1,16; 3,13; 2Tim 3,15; Cf. Ef 1,13. 228. Act 9,$42 ; 11,17 ; 16,31 ; 22,19$; Ef 1,15 ; «en el Hijo del hombre»: Jn 3,14-15. 229. $\operatorname{Rm} 9,23+10,11+1$ Pe $2,6=$ Is 28,16 . 230. Jn 14,1 ; 1 Pe 1,21 ; Cf 1 Tes 1,8 ; Mc 11,24 (=Mt 21,22); Mt 17,20. 231. Jn 3,36; 6,29.40; 1 Jn 5,10; Cf. Jn 2,11; 3,16.18; 11,25-26 etc. 232. Cf. Act 19,24;20,21;24,24; Gál 2,16; Col 2,5 etc. La construcción «pistéuein eis» [ =creer en] + acusativo, ignorada tanto por el griego profano como por el de los LXX (Cf. R. Bultmann, a.c., 203), es frecuentemente usada $(=45 \mathrm{x})$ por el NT y, por tanto, especificamente cristiana (Cf. Id., a.c., 203204.209), como su correspondiente latina [ = «credere in»] es propia y exclusiva del latín cristiano 
Hijo ${ }^{231}$ Jesucristo ${ }^{232}$. Una entrega o fe en Dios ${ }^{233}$ y en Cristo ${ }^{234}$, nunca deiraudada y sí esperanzadoramente sostenida por la total confianza en Quien "entregó a su Hijo por nosotros» y en Quien «por nosotros murió cuando aún éramos pecadores» ${ }^{235}$ o malvados: «jSé a quién me he confiado!» ${ }^{236}$. Pues esa confianza se arraiga también en la sólida garantía de los salvíficos efectos producidos por la fe en el creyente: El perdón de los pecados ${ }^{237}$ y la justificación ${ }^{238}$, el don del Espíritu Santo ${ }^{239}$ y de la filiación divina ${ }^{240}$ así como el de la incoada «vida eterna» ${ }^{241}$ y la promesa de la salvación ${ }^{242}$. De ahí que «la fe -en la que se basa «el plan salvífico de Dios» (1Tim 1,4) - es garantía de lo que se espera, [la] prueba de las realidades invisibles» (Hebr 11,1): Los efectos salvíficos, producidos por la fe en el creyente, son ya incoada posesión de dones celestes $y$, por eso, «garantía» segura de su plena posesión futura así como «prueba» firme de que esos bienes «invisibles» existen. Audición de la Palabra, asentimiento personal, confiado apoyo y entrega total son, pues, las principales etapas recorridas por quienes «caminan en la fe» ${ }^{243}$ : No sólo «perseverando» y «conservando» la recibida «fe primera»" ${ }^{2+4}$, sino también «afirmándose» en ella ${ }^{245}$ y «progresando» ${ }^{246}$ desde la «poca fe» ${ }^{247}$ de «los débiles» en ella ( $\mathrm{Rm} 14,1)$, pasando por la «gran fe» ${ }^{248}$ de quienes, «firmes» en ella y. «armados» con ella ${ }^{249}$, trasladan «árboles» o «montañas» —insuperables obstáculos! - y lo pueden «todo» ${ }^{250}$, hasta «alcanzar» aque-

(Cf. supra, 67s: bibliogr.). No es cierto, sin embargo, que aquella construcción signifique ante todo «aceptación del kerygma sobre Cristo» (R. Bultmann, a.c., 209): Expresa la total autodonación a Dios y a Cristo, anunciados por el kérygma, aceptado éste con el total asentimiento o credito dado [= «pistéuein tô»] a su mensaje sobre Dios y sobre Cristo (Cf. supra, nn. 220-222), a quienes el creyente por tanto, «por la fe se entrega entera y libremente», ofreciéndoles «el homenaje total de su entendimiento y voluntad»: Conc. Vat. II, Const. DV 5. 233. "Fe de Dios» (= fe en Dios): Mc 11,22; $\mathrm{Rm} \mathrm{3,3.} \mathrm{234.} \mathrm{«fe} \mathrm{de} \mathrm{Cristo»} \mathrm{(=} \mathrm{fe} \mathrm{en} \mathrm{Cristo):} \mathrm{Gál} \mathrm{2.16.22:} \mathrm{Rm} \mathrm{3.22:} \mathrm{Fil} \mathrm{3.9;} \mathrm{(r.} \mathrm{Act} \mathrm{3,16;}$ Gál 3,20; Rm 3,26; Ef 3,12; Sant 2,1; Apoc 2,13; 14,12. 235. Rm 8,32; 5,8. 236. 2Tim 1,12. 237. Act 10,$43 ; 13,38-39 ; 26,18$; Cf. $3,16-19 ; 15,9 ; 26,18 ; 1$ Cor 15,17 . 238. Act 13,38-39; Gál 2,16; 3,6-9.24; Rm 3,22-30; 4,9-25; 5,1; 10,10a; Fil 3,9; Cf. Rm 9,30-31; 10,4; Ef 2,8-9; Col 2,12. Lo que implica la «paz con Dios»: Rm 5,1; Cf. 15,13; Ef 3,12. 239. Act 10,44 (=11,17); 19,2; Gál 3,2.5.14.16.22; Rm 12,3.6-8 + 1Cor 12,6-9; Ef 1,13. Mediante ese don del Espíritu Santo «habita Cristo por la fe en el corazón» de los creyentes: Ef 3,17; Cf. Rm 8,9-10.14s. 240. Gál 3,26; Cf. 4,6-7 = Rm 8,15s. Ese don implica ser «herederos de Dios»: Rm 8,17; Cf. Sant 2,5 (=del «Reino»). 241. Jn 3,15.36; 5,24; 6,40.47; 1Tim 1,16; Cf. Gál 3,11; Rm 1,17; Tit 1,1-2; Hebr 10,38. 242. Act 16,31; Rm 1,16;10,9-13; 1Pe 1,5.9; Lc 8,12; Jn 11,25-26; Cf. 2Tes 1,4-5; 1Cor 1,$21 ; 15,2 ; \operatorname{Rm} 13,11$; Col 1,22-23; 1 Tim 2,15; 2 Tim 3,15; Hebr 4,3; 10,39; Mc 16,16; Sant 2,5. 243. 2 Cor 5,7 ; Cf. 10,15 ; 1 Tim 6,$11 ; 2$ Tim 2,22. 244. 1Tim 2,$15 ; 5,12 ; 2$ Tim 4,7. Para conservar la fe y soslayar el riesgo de «la incredulidad, que haga apostatar del Dios vivo» (Hebr 3,12), es preciso orar: Cf. Lc 18,1-8; 2Tes 3,1-3. 245. 1Tes 3,2; 2Tes 3,2-3; 1Cor 16,13; Col 1,23; Act 16,5. 246. 2 Tes 1,$3 ; 2$ Cor 10,$15 ;$ Fil 1,25 . El progreso en la fe en un don divino, obtenido por la oración: «jeñor, auméntanos la fe!» (Lc 17,5; Cf. Mc 9,24). 247. Mt 6,30 (=Lc 12,28); 8,26; 14,31; 16,18; 17,20; Cf. Mc 9,24; Mt 21,21. Fe incompleta: 1Tes 3,10; Cf. 2Tes 1,11. 248. Mt 15,28; Cf. 8,10 (=Lc 7,9). 249. 2Cor 1,24 ; 1Pe 5,9; 1Tes 5,8; 1Tim 1,18-19; Ef 6,16; Cf. Rm 11,20 ; 1 Cor 16,13 ; Col 1,23; 2,5.7. 250. Mc 10,22-24 (= Mt 21,21-22); 9,23; Lc 17,5-6; 1Cor 13,2 . 
lla fe perfecta ${ }^{251}$, que no necesita ya de «signos» ${ }^{252}$ y sí «actúa por la caridad» ${ }^{253}$ o se manifiesta «en la práctica de las obras buenas» ${ }^{254}$, por ser la fe adulta de los que no sólo están «arraigados» en ella y son «fuertes» por ella, sino que «lo hacen todo con amor» y «rebosan en acción de gracias» ${ }^{255}$. La fe cristiana es, pues, fundamentalmente una progresiva experiencia personal de Dios y de su Hijo Jesucristo, realizada mediante la visión de «signos» salvadores y, sobre todo, la obediente audición de la Palabra sobre su victorioso poder e indecible amor, a quienes se presta un asentimiento personal y sobre quienes se apoya la propia historia, vivida - con la garantía de concretos dones salvíficos- en una progresiva entrega total a Dios, por quien el creyente se siente amado e impulsado a rebosar en alabanza y hacerlo todo con amor. Pues:

Creer es apoyarse por completo en la granítica roca del Señor, es hacer de su poder el fundamento de la historia, iluminada con su amor. Creer es confiar sólo y totalmente en la fuerza creadora del Señor, que con su Palabra omnipotente de la nada a la existencia al ser llamó. Creer es caminar por el fracaso con la mirada clavada en el Señor, a quien «nada es imposible» y cuyo brazo jamás ante la prueba se acortó. Creer es subir al monte Moria obediente al mandato del Señor, y ofrecerle al propio Isaac - ila propia historia! como el creyente Abraham se lo ofreció.

Creer es abandonar la propia vida en la potencia salvadora del Señor, que en las aguas de la muerte abrió una vía y a Israel de su tirano liberó. Creer es caminar por este mundo confiando en el próvido Señor, que a su Pueblo cuarenta años saciar pudo en el desierto, con la copia de su don.

Creer es decir sí como María al mesiánico anuncio del Señor, es decir - como ella dijo- «fiat» y acoger su Palabra como un don.

251. 1Tim 6,11; 1Cor 13,2-13. Esa fe perfecta es un «carisma» o «fruto» del Espíritu Santo: 1Cor 12,9; Gál 5,22; Ct 1Cor 13,2b. 252. Jn 4,48; 20,29b; 1Pe 1,8. 253. Gál 5,6; Cf. 1Cor 13,7; 1Tim 1,5. También: 1Tes 5,8; Gál 5,6; 1Cor 16,13-14; Col 1,4; 1Tim 1,14; 2,15; 2Tim 1,13; 2,22; 3,10. 254. Tit 1,5; Cf. Sant 2,21-25; 2 Pe 1,5. 255. 1Cor 16,13; Col 2,7. 
Creer es abandonarse al Padre eterno:

a su rica providencia y a su amor, es hacer de su voluntad el alimento que sacia el hambre y sed del corazón. Creer en Dios es invocarle «¡Abbá, Padre!» como Jesús constantemente le invocó, es orar como Él oró: «iLo que tú quieras, Padre, eso mismo y no otra cosa quiero yo!». Creer en Dios es amarle como a Padre, que «todo lo hizo bien» y el mal no creó, es vivir alabando su amor grande sobre todo ante la prueba y el dolor. Creer en Dios -en situación de cruz y muertees no dudar de su poder y amor, es confiar en el Padre omnipotente que a su Hijo de la muerte liberó. Creer en Dios es vivir cantando su gran sabiduría e inmenso amor, es afrontar la propia muerte como un paso - iuna Pascua! - hacia la casa del Señor. Creer en Dios - en suma - es vivir ya resucitados de la muerte: ¡Una vida para Dios!; es entregarse al Dios que nos ha amado sin reservas: ¡Viviendo de su amor!

Esa entrega total al «Dios-es-amor» o a las tres divinas Personas de la Santísima Trinidad expresa, sin duda, la introductora fórmula del Símbolo, por la que el creyente ( $=$ «creo en») o la comunidad de los creyentes (= «creemos en») se autoabandona del todo o «se entrega entera y libremente» al único Dios, reconocido como Padre, Hijo y Espíritu Santo, ofreciéndoles con ello «el homenaje total de su entendimiento y voluntad» ${ }^{256}$. Una entrega expresada, por lo demás, en:

\section{LA CONFESIÓN DE LA FE}

Además de la bibliografía general sobre la fe (supra, 123), Cf.: P. FEINE, Die Gestalt des apostolischen Glaubensbekenntnis im NT, Leipzig 1925, 41-79; O. MicheL, Homologéo: ThWNT V 199-220:206-17; P. BENOIT, Les origines du Symbole des Apôtres dans le NT: LumVie 2 (1952) 39-60:50-58; R. SCHNACKENBURG-E. ZELLER, Bekkentnis: LThK II 143-46; E. KAMLAH, Bekenntnis. III. Im NT: RGG I 991-93; W.A. QUAHWECK, Confession: IDB I 667s; V.H. Neufeld, The earliest christian confessions (NTTSt 5), Leiden 1963, 13ss; H. DE LUBAC, La foi chrétienne. Essai sur la structure du Symbole des Apôtres, Paris 1969, 31147; H. SCHLIER, a.c., (Supra, 12s. n. 7), 13-33.48ss; O. CullmanN, Las primeras confesiones de fe cristiana: «La fe y el culto en la Iglesia primitiva», Madrid 1971, 63-122; H.F. CAMPENHAuSEN, Das Bekenntnis im NT: ZNW 63 (1972)

256. Conc. Vat. II, Const. DV 5; supra, $67 \mathrm{~s}$. 
210-53; B. LANG, Confesiones de fe en la S. Escritura: Conc. 138 (1978) 13-23; X. PIKAZA, Las confesiones de fe en la Biblia: Communio 2 (1979) 7-19; J.N.D. Kelly, o.c., 13-29 (trad. españ., 30-45); N. BROX, Confesión: CFT I 216-220. (Más bibliografía: supra, 12-14, nn. 7 y 22).

La introductora fórmula del Símbolo expresa también la pública confesión individual (= «creo en») o comunitaria (= «creemos en») de la Iglesia sobre la existencia y obra salvífica del Dios uno y trino ${ }^{257}$. Síntesis aquél de la fe que justifica, es también el más logrado compendio de la confesión que salva: «Si confiesas con la boca que Jesús es el Señor y crees que Dios le resucitó de entre los muertos, serás salvo; pues con el corazón se cree para obtener la justificación, y con la boca se confiesa para conseguir la salvación» ( $R \mathrm{~m}$ 10,9-10). Así formuló san Pablo la relación entre fe justificante y confesión salvadora: Aquélla, concentrada en el evento salvífico de la resurrección de Jesús por Dios ${ }^{258}$, otorga ciertamente al creyente la justificación (Cf. supra); no le garantiza, sin embargo, la salvación definitiva o eterna, reservada más bien a su pública confesión [= homología»] oral de Jesucristo como «el Señor». No basta, pues, creer: Es necesario también confesar la propia fe. No basta la fe interior del «corazón»: Es necesaria la confesión exterior de «la boca». La fe suscitada «en el corazón» del creyente, mediante la audición de la Palabra predicada por el «enviado» o mensajero ${ }^{259}$, debe traducirse en la confesión exterior por la palabra de aquel, quien a su vez deviene así testigo y mensajero de su fe ante los hombres: «`Creemos, por eso hablamos!» ${ }^{260}$. Quien no «habla» o anuncia la fe recibida, prueba que la suya no es aún fe verdadera o adulta: ¡No es posible ser «sal» sin «salar», ni «luz» sin «iluminar»! La verdadera «sal» necesariamente «sala», como la «lámpara» realmente «encendida» no puede menos de «iluminar». Y el verdadero creyente cristiano es fundamentalmente «sal de la tierra» y «luz del mundo» ${ }^{261}$ : Fue «salado» por la fe, para «salar» a los hombres de «la tierra»; fue «iluminado» por la fe bautismal ${ }^{262}$ y devino «hijo de la luz» ${ }^{263}$, para «iluminar» a los hombres «del mundo» ${ }^{264}$, habiendo recibido la fe «en el corazón», para confesarla «con la boca». Como «no sirve para nada la sal desvirtuada» ni se puede «esconder bajo el celemín la lámpara encendida» ${ }^{265}$, tampoco la fe recibida «en el corazón» debe quedar oculta en él: ¡Tiene que devenir confesión oral! Ésta es, pues, complemento necesario y perfección de la fe interior, como la justificación se complementa y culmina en la salvación eterna, «meta de la fe» ${ }^{266}$. Lo que significa: El creyente perfecto es el confesor de la fe.

Así lo refleja la historia bíblica de los creyentes. Ya Israel primero y el judaísmo después, en efecto, confesaron su fe en el único Dios salvador, a quien

257. Cf. supra, 68. 258. 1 Cor $15,1-11,14.17$; Rm 4,24-25; 2 Cor 1,$9 ;$ Col 2,12 . 259. Rm 10,14-17. 260. 2Cor 4,13. 261. Mt 5,13-16; Cf. Mc 9,50 (=Lc 12,49); Fil 2,15. 262. Hebr 6,4; 10,32; Ef 5,14; Cf. 2Cor 4,4.6; Ef 1,18; 2Tim 1,10. 263. Lc 16,8; Jn 12,36; 1Tes 5,5. 264. Mt 5,16. 265. Mt 5,13.15. 266. 1Pe 1,9; Cf. 1,5; 1Tes 1,4-5; 1Cor 15,2; Rm 1,16; 10,9-13; Col 1,22-23; 1 Tim 2,15; Hebr 4,3; 10,39; Sant 2,5; Lc 8,12; Mc 16,16 etc: Cf. supra, n. 242. 
también confesó Jesús, designándole sobre todo «el Padre» ${ }^{267}$. No se limitó a ésa, sin embargo, su confesión: Pablo precisa, que Jesús «dio testimonio —bajo Poncio Pilato- de la bella confesión pública» ${ }^{268}$, atestiguando efectivamente ante las autoridades judaicas y ante el procurador romano ser «el Mesías, el hijo del Bendito» y «el (mesiánico) Rey de los judíos» ${ }^{269}$. ¡Esa confesión le costó la vida! El «iniciador y perfeccionador de la fe» ${ }^{270}$ inició y perfeccionó así también la confesión de la fe, por Él exigida a sus primeros DisCíPULOS: Enviados «como ovejas entre lobos» a evangelizar la Buena Nueva, serán por éstos no sólo «perseguidos» y entregados «a los tribunales» sino también presentados «ante gobernadores y reyes, para dar testimonio ante ellos y ante los paganos» de su fe ${ }^{271}$ o «confesarle públicamente ante los hombres» ${ }^{272}$. ¿El contenido de esa confesión?: Afirmar públicamente y sin ambages que «Jesús es el Mesías» ${ }^{273}$ o el único Salvador; y esto al precio incluso de su vida ${ }^{274}$ : ¡De esa confesión o testimonio público depende su salvación eterna! ${ }^{275}$. Análoga confesión pública es exigida, por lo demás, a todo CRISTIANo. Éste, en efecto, debe no sólo «creer en» Jesús sino también «confesar públicamente» su dignidad mesiánica, incluso al riesgo de ser marginado por los enemigos de esa $\mathrm{fe}^{276}$, confesando asimismo tanto la realidad de su encarnación como de su filiación divina, ante quienes una y otra niegan ${ }^{277}$ : ¡No es

267. Cf. supra, 12-13. La monoteística confesión judaica «Dios es uno» (Cf. E. Stauffer, ThWNT III 98s; V.H. Neufeld, o.c., 36s) significaba apostasía de la politeística religión romana (Cf. V.H. Neufeld, o.c., 38-41), y por ello costó la vida a muchos creyentes del Judaísmo: Rabbí Aqiba (s. II d.C.), por ejemplo, fue martirizado y murió recitando el «Shemá» (TbBer 61b). 268. 1Tim 6,13: La preposición epi + gen. personal puede significar «en tiempo de» (Mt 1,11; Lc 4,27 etc) o «bajo el gobierno de» (Mc 2,26; Lc 3,2; Act 11,28), envolviendo este significado en 1Tim 6,13: Para designar «delante de» o «en presencia de» usa Pablo, en ese contexto, otro vocablo: «Enópion» (1Tim 6,12b-13a). Así con: Ch H. Turner, ITim 6,12-13: «Epi Pontiou Pilatou»: JThS 28 (1926-27) 270-76:272; P. Dornier, Les Epîtres Pastorales, Paris 1969, 106s. 269. Mc 14,6162par; 15,2par; Jn 18,33-37; Cf. a este respecto: O. Michel, a.c., 211; S. Sabugal, Christos, 101110. 270. Hebr 12,2 . 271. Mt $10,16-18=$ Lc 10,$3 ; 21,12-13$. 272. Mt $10,32-33=$ Lc 12,8-9; Cf. a este respecto: O. Michel, a.c., 207s. La confesión pública u homología cristológica está, pues, estrechamente relacionada con el testimonio cristiano sobre Cristo (Mt 10,18.32; Jn 1,19-21.32-34; Cf.: V.H. Neufeld, o.c., 29,32; S. Sabugal, o.c., 182-86), siendo aquélla un aspecto fundamental e insustituible de ese testimonio, requerido con apremio por el Magisterio hodierno a todos los cristianos (Conc. Vat. II, Const. LG 21.28.32.35.38.39.42; Const. GS 43; Decr. ChD 11.15; Decr. AA 13; Decr. AG 11; Pablo VI, Exh. aspot. EN 41): Cf. S. Sabugal, La embajada mesiánica de Juan Bautista, Madrid 1980, 221-222.223. 273. Jn 9,22; 12,42; 1Jn 5,1; Cf. Mc 8,29par; Act 5,42; 9,22; 17,3; 18,5.28; Jn 1,19-21; 1 Jn 2,22; 4,2-3; 2Jn 7. Las confesiones: «Jesús es el Descendiente de David» (Mt 12,23) o «el Rey de Israel» (Jn 1,49) y «el Rey de los judíos» (Mc 15,2par; Jn 18,33.37.39; 19,3.19) y «el Hijo de Dios» (Mt 4,3.6 [=Lc 4,3.9]; Mc 3,11 $=\mathrm{Lc} 4,41)$ se reducen a aquélla, posteriormente completada con la confesión de su filiación divina (Mt 16,16; Jn 11,27;20,31), siendo la más antigua homología cristológica: «Jesús es el Mesías» (Cf. V.H. Neufeld, o.c., 108-26.142s; S. Sabugal, Christós, 85-94:92s). 274. Cf. Mt 10,21-22.28 = Lc 12,4. 275. Cf. Mt 10,32b-33 (=Lc 12,8b-9); Apoc 3,5. 276. Jn 9,22; 12,42; Cf. 1Jn 5,1. A este respecto, Cf.: O. Michel, a.c., 208s; S. Sabugal, Christós, 304-318.37679. 277. $1 \mathrm{Jn} 2,22-23 ; 4,2-3.15 ; 5,5 ; 2 \mathrm{Jn} 7$; Cf. a este respecto: O. Michel, a.c., 210; V.H. Neufeld, o.c., 70-72.98-105; S. Sabugal, Christós, 379-86. 
cristiano quien rehúsa tal confesión! ${ }^{278}$. Tampoco lo es quien no hace suya la confesión públicamente profesada en el culto: «¡Jesús es el Señor!» ${ }^{279}$. Pues «nadie» puede pronunciar esta confesión «sino por influjo del Espíritu Santo» ${ }^{280}$ : ¡No posee a éste quien no confiesa a «Jesús» como «el Señor» o el Resucitado constituido por Dios supremo Dominador de todo! Él es, pues, el objeto personal de la pública confesión cristiana ${ }^{281}$. No el único. Pues el verdadero cristiano, a diferencia de quienes «profesan conocer a Dios, mas le niegan con sus obras» (Tit 1,15-16), también confiesa públicamente la fe en $\operatorname{Dios}^{282}$, reconociendo que existe «un solo Dios Padre» y «un solo Señor Jesucristo» y «un solo Espíritu» ${ }^{283}$, por haber «sido lavado, santificado y justificado en el nombre del Señor Jesucristo y en el Espíritu de nuestro Dios» ${ }^{284}$, es decir, bautizado «en el nombre del Padre y del Hijo y del Espíritu Santo» ${ }^{285}$. Ésta es, sin duda, «la bella confesión pública» bautismal, profesada a raíz del bautismo «ante (los) muchos testigos» de la comunidad cristiana por Timoteo y por todo cristiano, debiendo asimismo renovarla constantemente para «combatir el buen combate de la fe» y «conquistar la vida eterna» ${ }^{286}$ : ¡No se puede vencer aquel combate diario ni lograr esta conquista, sin renovar diariamente esa bautismal confesión pública o el Símbolo! Pues sólo esa profesión de fe garantiza al creyente tanto la victoria sobre «el enemigo» diabólico ${ }^{287}$ como «la salvación» eterna, siendo por ello «la confesión de la esperanza» ${ }^{288}$. De ahí la exhortación a «mantener firmes la confesión pública» ${ }^{289}$, compendiada por la Iglesia en el Símbolo: iMantengámoslo con fidelidad! Una exhortación, por lo demás, particularmente actual. Pues si la ortodoxa confesión del Símbolo garantiza la unidad de la fe ante el legítimo pluralismo teológico de nuestro tiempo ${ }^{290}$, aquélla está llamada también a jugar un papel deccisivo en el iniciado empeño por restañar la quebrada unión de los creyentes en Cristo ${ }^{291}$. Por lo demás, la urgente tarea hodierna de la evangelización y cate-

278. Cf. Jn 12,$43 ; 1 \mathrm{Jn} 2,22 ; 4,3$. 279. Fil 2,11; Cf. Rm 10,9; 1Cor 8,6; a este respecto, Cf. V.H. Neufeld, o.c., 43-44.51-68. 280. 1Cor 12,3: No es cristiano «quien no tiene el Espíritu de Cristo» $(\operatorname{Rm} 8,9)$. 281. Cf. también: Hebr 3,1; 4,14. 282. Tit 1,16; Hebr 13,15; Cf. Sant 2,19. «Dios es uno» (1Cor 8,6; Gál 3,20; Rm 3,30; 1Tim 2,5) y «único» (1Cor 8,4; Rm 16,27; 1 Tim 1,17; 6,15; Jds 25; Apoc 15,4). Tras esta profesión de fe monoteísta late, sin duda, la polémica contra el politeísmo pagano (1Cor 8,4-6; Cf.: E. Stauffer, Theós: ThWNT III 101s; K. Rahner, Theós en el NT, en: «Escritos de Teología», I, Madrid 1961, 93-167:118). Ya Jesús condividió en pleno la confesión veterotestamentaria y judaica sobre el «único Dios» (Mc 12,2829par: Cf. supra, 12s.), enseñando asimismo, - -en el contexto de su mensaje central sobre el Reinado de Dios-, que «no se puede servir a Dios y al dinero» (Mt 6,24 = Lc 16,13), sin duda por ser aquél «el único Dios verdadero» (Jn 17,3). Parece, pues, claro que «la confesión del único Dios verdadero es uno de los elementos centrales del mensaje de Cristo»: K. Rahner, o.c., 117 (lo cursivo es nuestro). 283. Ef 4,4-6; Cf. 1Cor 12,4-6; 2Cor 1,21-22; 13,14; 1Tes 5,18-19; 1 Pe 1,2. 284. 1 Cor 6,11 ; Cf. 2 Cor 1,21-22. 285. Mt 28,19. 286. 1Tim 6,12. 287. Para vencerle, hay que «resistirle firmes en la fe» (1Pe 5,8): i«Embrazando» su «escudo»! (Ef 6,12-13.16): El "escudo del Símbolo», como lo hemos subrayado en sintonía con varios e ilustres comentaristas antiguos (Cf. supra, 9-10). 288. Rm 10,10; Hebr 10,23. 289. Hebr 4,14; 10,23: Esa «homología» es probablemente la bautismal confesión de la fe: Cf. O. Michel, a.c., 216. 290. Cf. supra, 30-33. 291. Cf. supra, 33-38. 
quesis, que incumbe «a todo discípulo de Cristo» ${ }^{292}$, no puede realizarse sin la confesión pública de la fe recibida, obligación recordada y encomiada con particular apremio por el hodierno Magisterio de la Iglesia a todos los fieles: ¡Todos ellos «están obligados a confesar ante los hombres la fe que recibieron de Dios mediante la Iglesia» ${ }^{293}$, uniendo «a la vida según la fe la profesión de la fe» en la propia vida ${ }^{294}$.

¡De tales confesores necesita particularmente hoy la Iglesia!: En el contexto histórico de una humanidad, que sólo exige la justicia y ha puesto su confianza preponderantemente en el poder y en el dinero, en el trabajo, el progreso y el sexo, seudocatequizada sin cesar por falsos profetas a creer y apoyar la propia vida en los fascinantes ídolos de «este mundo», es imprescindible y urgente la presencia de testigos cristianos, que en la familia y fuera de ella, -en los centros de trabajo y de enseñanza, de comunicación social y de recreo-, anuncien y practiquen la misericordia del Padre y su gratuito amor a los pecadores ${ }^{295}$, confesando asimismo de palabra y con las obras de una vida según el Evangelio, que Jesús es el único Salvador del hombre así como el único Señor, dotado por Dios con el poder sobre toda realidad de sufrimiento $y$ de muerte.

292. Conc. Vat. II, Const. LG 17; Decr. AG 23; Cf. Pablo VI, Exh. apost. EN 59-73; Juan Pablo II, Exh. apost. CT 62-71. 293. Conc. Vat. II, Const. LG 11: El Magisterio reitera esta obligación (Cf. Decr. UR 12), subrayando que si el martirio o «la efusión de la sangre» por Cristo «es don concedido a pocos, sin embargo todos deben estar dispuestos a confesar a Cristo delante de los hombres y a seguirle por el camino de la cruz, en medio de las persecuciones, que nunca faltan a la Iglesia» (Const. LG 42). 294. Conc. Vat. II, Const. LG 35; Cf. Pablo VI, Exh. apost. EN 41. Esa confesión de la fe en la propia vida es parte del testimonio cristiano (Cf. V.H. Neufeld, o.c., 29-32): Con éste se relaciona, en efecto, la homología o confesión pública de la fe (Mt 10,18.32; 1Tim 6,13; Jn 1,19-21.32-34) por Juan Bautista (Jn 1,19-21.32-34), por los discípulos de Jesús (Mt 10,18.32) y por Jesús mismo, quien, dando «testimonio bajo Poncio Pilato de la bella confesión pública» (1Tim 6,13), al precio de su muerte, devino «el Martir» (=Confesor) por excelencia (Apoc 1,5) y modelo supremo de «los mártires» cristianos (Act 22,20; Apoc 2,13; Anónimo, Mart. Polic., 2,2; 14,2; 15,2) o de quienes sufrieron el «destierro» (Apoc 1,9) y la muerte (Apoc 6,9) «a causa de la Palabra de Dios y del testimonio de Jesús» (Apoc 1,9; 6,9), pues le confesaron al precio de su vida: ¡«No amaron la vida ante la muerte»! (Apoc 12,11). 295. Cf. Juan Pablo II, Enc. DM VII 12-14. 


\section{Dios, PAdRe OMNipotente y CREADOR *}

En el primer artículo del Símbolo confesamos individual o comunitariamente nuestra fe -certeza segura, incondicionado sí, total entrega- en un solo «Dios», a quien designamos «Padre omnipotente» por ser el «Creador del cielo y de la tierra». Esa confesión de fe, por tanto, afirma ante todo:

\section{1. ¡DIOS EXISTE!}

Cf.: P. HEINISCH, Theologie des AT, Bonn 1940, 5-11; M. REHM, Das Gottesbild im $A T$, Würzburg 1951, 7-8; P. vAN IMSCHOOT, Théologie de l'AT, I, Tournai 1954, 6-7; K. RAHNER, Theós en el NT: «Escritos de Teología», I, Madrid 1961, 93-167:110-16 [ = ET I]; L. KöHLER, Theologie des $A T$, Tübingen 41966, 1-2; M. García Cordero, Teología de la Biblia, I, Madrid 1970, 177-88.

La existencia de Dios es una verdad de fe, confesada siempre por la Iglesia, cuyo Magisterio definió «que hay un solo Dios verdadero» y excluyó, por ello, de su comunidad a quien «negase» aquélla ${ }^{1}$. El vocablo «Dios» ${ }^{2}$ - $\tan$

* Cf. C. Blume, Das apostolische Glaubensbekenntnis, Freiburg 1893, 124-27; Th. Zahn, Das apostolische Symbolum, Erlangen-Leipzig 1893, 49-52; S. Bäumer, Das àpostolische Glaubensbekenntnis, Mainz 1893, 179-82; F. Kattenbusch, Das apostolische Symbol, II, Leipzig 1900, 501-54.875-78; P. Feine, Die Gestalt des Apostolischen Glaubensbekenntnis in der Zeit des Neuen Testaments, Leipzig 1925, 89-94; I. Ortiz de Urbina, El Símbolo Niceno, Madrid 1947, 64-98; AA.VV., Il Simbolo, I, Assisi 31961, 77-204; C. Eichenseer, Das Symbolum Apostolicum beim Hl. Augustinus, St. Ottilien 1960, 163-99; J. Ratzinger, Einführung in das Christentum, München 1968, 71-150 (trad. españ., 75-119); Id., Ich glaube an Gott den Vater...: «Ich glaube» (hrsg. W. Sandfuchs), Würzburg ${ }^{3}$ 1975, 13-24; W. Beinert, Das Glaubensbekenntnis der Oekumene, Freiburg 1973, 49-66; W. Pannenberg, La Fe de los Apóstoles, Salamanca 1975, 28-58; A. de Halleux, «Dieu le Père tout-puissant»: RThL 8 (1976) 401-422; G.-M. Carrone-M. Maziers, La foi de L'Église, Paris 1978, 83-133; Ph. Schäfer, Einführung in das Glaubensbekenntnis, Mainz 1979, 24-33 (trad. españ., Santander 1983, 33-46); J.R. Flecha, Creo en Dios Padre todopoderoso: AA.VV., «El Credo», Madrid 1982, 28-47; J. Martín-A. González, El Credo de los cristianos, Madrid 1982, 20-44.

1. Conc. Vat. I, Const. Dei.Filius 1: Denz. 1782.1801. 2. Cf.: AA.VV., Dieu: DThC IV 756-1300; AA.VV., Gott: ThWNT III 65-120; AA.VV., Gott: RGG II 1701-45; AA.VV., Gott: 
antiguo como el hombre y permanente mientras este exista $-{ }^{3}$ expresa, pues, el primer objeto formal de la fe confesada en el Símbolo, constituyendo aquél la piedra basilar de la fe cristiana. Nada de extraño, por tanto, si su mención aparece ya en el primer versículo de la Biblia (Gén 1,1) y recorre prácticamente todas las páginas de los Libros Sagrados ${ }^{4}$. Para sus Autores, en efecto, la existencia de Dios ${ }^{5}$ no necesita demostración alguna, por ser perceptible doquier con la claridad de «una evidencia» total ${ }^{6}$ :

1) Se impone, ante todo, a la simple mirada de la revelación natural o a

LThK. IV 1070-87; H. Urs von Balunasar, El problema de wios en el homivit ". !ual, Maciid 2196ó; Id., Saggi Teologici, III, Brescia 1972, 11-47.253-67.283-96; F. Gogarten, Die Frage nach Gott, Tübingen 1968; H.J. Schultz (ed.), Was ist eigentlich Gott?, München 1969; K. Rahner, a.c.; Id., Schriften der Theologie, IX, Einsiedeln 1970, 161-76; X, Einsiedeln 1972, 134-44; XIII, Einsiedeln 1978, 111-28; Id., Curso fundamental sobre la fe, Barcelona 1979, 65-116; AA.VV., Dios: SM II 298-356; J. Ratzinger, o.c., 71-150 (trad. españ., 75-159); Id. (dir.), Dios como problema, Madrid 1973; Ch. Chabanis, Dieu existe-t-il? Non, répondent..., Paris 1973; Id., Dieu existe-t-il? Oui, Paris 1979; J. Coppens (ed.), La notion biblique de Dieu (BEThL 41), GemblouxLeuven 1976; W. Pannenberg, Cuestiones fundamentales de teología sistemática, Salamanca 1976, 93-210; AA.VV., Dios: CFT I 330-361; H. Küng, Existiert Gott? Antwort auf die Gottesfrege der Gegenwart, München 1978 (trad. españ., Madrid 1979); W. Kasper, Der Gott Jesu Christi, Mainz 1982; M.F. Sciacca (dir.), Pro e contro Dio. Raccolta sistematica degli argomenti pro e contro l'esistenza di Dio, I-II, Milano 1982. 3. K. Rahner, Curso..., 66-73, 4. A este respecto, además de los artículos generales sobre «Dios» (E. Mangenot, Dieu: DThC IV 9481023; G. Quell-E. Stauffer, Theós: ThWNT III 79-120; G. Quell-W. Foerster, Kýrios: Ib., 105680.1085-87; E. Wüthwein-E. Fascher, Gott: RGG II 1705-17; A. Deissler-F.H. Schierse, Gott: LThK VI 1076-80; B.W. Anderson-C.F.D. Moule, God: IDB II 407-36; A. Deissler-R. Schnackenburg, Dios: DTB 273-95; J. Guillet, Dios: VTB 241-50; J. Haspecker, Dios: CFT I 343-52; J. Schneider, Dios: DTNT II 31-45; H.D. Betz, Theós: EWNT II 346-52) y los respectivos estudios en las teologías bíblicas (P. Heinisch, o.c., 5-99; P. van Imschoot, o.c., I 6-90; L. Köhler, o.c., 1-113; E. Jacob, Théologie de l'AT, Neuchâtel 21968, 29-95; M. García Cordero, o.c., I 315-71; II 337-488; G. von RAD, Teología del AT, I, Salamanca 1972, 184-204.234-42.262-80; W. Eichrodt, Teología del AT, I, Madrid 1975, 163-262; II 25-53; K.H. Schelkle, Teología del NT, II, Barcelona 1976, 370 467), Cf. los estudios monográficos de: J. Hehn, Die biblische und die babilonische Gottesidee, Innsbruck 1911,213-3.92; R.A. Hoffmann, Das Gottesbild Jesu, Hamburg 1934; K. Holzey, Jahwe der Gott Israels (AAbh. XII 4), Münster 1936; M. Rehm, o.c.; M. Schmaus, o.c., I 175-217; K. Rahner, ET I 93-167; id., Curso..., 65-116; T.W. Manson, The teaching of Jesus, Cambridge 1963, 89-170; AA.VV., Mysterium Salutis, II.1, Madrid 1969, 77-165.262-322; A. Deissler-W. Thüsing, Dios como problema (ed. J. Ratzinger), Madrid 1973, 61-120; S. Verges-J.M. Dalmau, Dios revelado por Cristo, Madrid 21976, 8-181; AA.VV., La notion biblique de Dieu (ed. J. Coppens), Gembloux-Leuven 1976; B. Lang (ed.), Der einzige Gott. Die Geburt der biblischen Monotheismus, München 1981; C. Westermann, Dieu dans l'AT, Paris 1982; J. Auer, Dios uno y trino, Barcelona 1982, 136-82; W. Kasper, o.c., 151-87. Sobre la concepción de Dios en los Padres de la Iglesia, Cf.: X. Le Bachelet, Dieu. Sa nature d'après le Pères: DThC IV 1023-1152; G.L. Prestige, God in patristic thought, London 1936; B. Studer, Dio: DPAC I 958-66. 5. A este respecto, además de los autores citados al principio (supra), Cf. M. Schmaus, Teología Dogmática, I, Madrid 1960, 175-189. 6. L. Köhler, o.c., 1; así para los Autores del AT (Cf. también: P. Heinisch, o.c., 5; M. Rehm, o.c., 7; P. van Imschoot, o.c., I 6). También los Autores del NT reflejan «la evidencia de la conciencia de Dios» e ignoran, «en realidad, el problema de su existencia...: Dios existe, esto es lo primero": K. Rahner, ET I 110. 
la contemplacion «limpia» de los seres creados ${ }^{7} \mathrm{y}$, en particular, del hombre ${ }^{8}$, a quien «Dios... manifestó desde la creación del mundo... Su poder eterno y su divinidad», de modo que «de la grandeza y hermosura de las criaturas» puede «por analogía llegar [aquél] a la contemplación de su Autor» ${ }^{9}$ : ¡Desde la existencia de las criaturas a la existencia de su Creador! Un razonamiento prolongado luego por los Padres de la Iglesia ${ }^{10} \mathrm{y}$, más tarde, filosóficamente elaborado en las «cinco vías» o modos de conocer a Dios: Elevándose la razón humana desde el movimiento de las criaturas al Dios inmóvil, desde las causas eficientes del mundo al Dios incausado, desde la contingencia e imperfección de los seres al Ser necesario y perfecto, desde el sabio gobierno del cosmos a su inteligentísimo Autor ${ }^{11}$. Éstas y otras pruebas de la existencia de Dios ${ }^{12}$ «no han perdido nada - ial contrario! - de su vitalidad, oportunidad y seguridad» ${ }^{13}$, pues son la escalera racional del hombre - desde sí y desde el

7. Cf. Sal 8 ; 19,2-7; 104; Jb 38,4-39,30; Is 40,25-31; Sab 13,1-9; Mt 5,34-35.45; 6,26-30 $(=$ Lc 12, 22-31); Act 14,15-17; 17,24-28; Rm 1,19-20: Cf. H.J. Horn, Gottesbeweis: RAC XI 951-77:960.962-63. 8. Cf. Sal 8,4-9; Mt 5,45;6,26-30 (=Lc 12,22-31); Act 17,27-29. 9. Rm 1,19-20; Sab 13,5; Cf. Act 14,17. A este respecto, Cf.: H. Schlier, Über die Erkenntnis Gottes bei den Heiden (nach dem NT): EvTh 2 (1935) 9-26; C. Larcher, De la nature à son A uteur d'après le Livre de la Sagesse: LumVie 3 (1954) 53-62; A. Feuillet, La connaissance naturelle de Dieu par les hommes d'après Rom 1,18-23: Ib., 63-80; H.Ott, Röm 1,19ff. als dogmatisches Problem: MüThZ 15 (1959) 40-50; R. Latourelle, Théologie de la révélation, Bruges-Paris 21966, 403-13; $\mathrm{M}$. Rese, Hellenistic influence on the Book of Wisdom and its consequences, Rome 1970, 50-62; A.-M. Dubarle, La manifestation naturelle de Dieu d'après l'Écriture (LD 91), Paris 1976; H.-J. Horn, a.c., 962s. 10. Cf.: Atenágoras, Legación, 16; Id., Sobre la resurrección de los cuerpos, 12-13; Taciano, Discurso, 4; Teófilo A., A Autólico, I 4-7; Minucio Félix, Octavio, 17; San Ireneo, Adv Haer., II 9,1; Tertuliano, Apoleg., 17; Id., Adv. Marc., I 10-14; Novaciano, De Trin., III 20; VIII 40; Orígenes, De princ., II 1-3; Contr. Celso, I 23; VII 37; San Atanasio, Contr. Gent., 34; San Gregorio Naz., Orat., 28,16; San Gregorio Nis., Contr. Eunom., 2; Orat. Cath., 12; San Juan Cr., In Rom. Hom. 3,2; San Ambrosio, In Hexam., I 1,4.16; San Agustín, Serm. 141,2; De Gen.ad litt., IV 32; Conf. X 6,9; San Cirilo A., Adv. Iulian., 3; etc. A este respecto, Cf.: X. Le Bachelet, a.c., 1027ss; C.L. Prestige, o.c., 55-57; H.-J. Horn, a.c., 963-73; B. Studer, a.c., 964s. 11. Sto. Tomás A., Sum. Theol., I 2,3: Cf. M. Schmaus, o.c., I 203-207. 12. Cf.: Atenágoras, Legación, 4-8; Teófilo A., A Autólico, I 2-7; Tertuliano, Apoleg., 17,6; De anima, 2-4; San Agustín, De vera religione, 30,56; 31,57; 39,72; Conf. VII 10,16; X 17,26; 24,35; 25,36; 27,38; Enarr. in Ps. 41,7-8; De libero arbitrio, 6,14; 12,33-34; 15,39; De civ. Dei, XI 26; San Anselmo, Proslogio, 2-3; San Buenaventura, Itinerario de la mente a Dios, I-IV; J.D. Escoto, In Sent., I,II 2; R. Descartes, Discurso del método, IV; Meditaciones, III.V; Principios de filosofía, I (Cf. G. Fraile, Historia de la Filosofía, III, Madrid 21978, 523-31); B. Spinoza, Ética, I pr. 11 (Cf. G. Fraile, o.c., III 615s); G.G. Leibniz, Monadología, 43-44; Principios de la naturaleza, 7; Teodicea, I 7 (Cf. (i. Fraile, o.c., III 678s); M. Blondel, L'action, Paris 1893, 339-56; La pensée, I; Paris 1934, 169-204:182ss; L'Être et les êtres, Paris 1935, 9-12.40-141: 132ss; L'action, II, Paris 1937, 175-367; La philosophie et l'esprit chrétien, Paris 1944, 39s; G. Marcel, Journal métaphysique, Paris ${ }^{3} 1935$, 32-38; Être et avoir, Paris 1935, 38-40.174-76; X. Zubiri, El hombre y Dios, Madrid 3 1985, 118-49.307-45; y otros autores. A este respecto, Cf. W. Kasper, o.c., 133-150. Los testimonios del antiguo y hodierno pensamiento filosófico a favor - y contra - la existencia de Dios han sido recogidos por M.F. Sciacca (dir.), o.c., I 5-664; II 7-738; Cf. también: H. Krings-E. Simons, Dios: CFF I 584-615; Ch. Chabanis, Dieu existe-t-il? Oui, Paris 1979, 27-527. 13. M. Blondel, La pensée, I, Paris 1934, 397; así también M. Schmaus, o.c., I 204.206, Sobre las pruehas de la existencia de Dios, Cf.: L. Scheffczyk, Dios: SM II 310s; K. Rahner, Curso..., 92-95. 
mundo- al Creador, el «itinerario de la mente» humana en su «divina subida» hacia Dios ${ }^{14}$, constituyendo en este sentido «la base natural y firme, sobre la que se asienta nuestra fe» ${ }^{15}$. Así lo ha reconocido, por lo demás, el Magisterio de la Iglesia, al enseñar que «Diọ, creando y conservando el universo por su Palabra, ofrece a los hombres en la creación un testimonio perenne de sí mismo», pudiendo por tanto «el hombre conocer ciertamente a Dios - principio y fin de todas las cosas- con la razón natural, por medio de las cosas creadas» ${ }^{16}$, cuya contemplación «pura», en efecto, no abriga duda alguna que:

«Mil gracias derramando

pasó por estos sotos con presura

e, yéndolos mirando,

con sola su figura

vestidos lọs dejó de su hermosura» ${ }^{17}$.

Es cierto, que tanto la casi exclusiva concepción técnica del mundo como la mentalidad secularizante del hombre hodierno han contribuido sensiblemente, a que éste perdiese en gran medida esa contemplación natural e inmediata de Dios, cuyos vestigios - $i$ «vestigia Dei»! - sustituye por doquier la huella humana ${ }^{18}$; de ahí que «la pregunta sobre Dios haya devenido actualmente tema central de la teología» ${ }^{19}$. No es menos cierto, sin embargo, que precisamente la concepción científica del mundo puede - hoy como ayer- facilitar el acceso a la fe en Dios e, incluso, arraigarla. Es lo que refleja el testimonio antiguo y hodierno de varios de entre los numerosos científicos creyentes:

«¿Quién, mediante la constante observación... del orden maravilloso del universo guiado por la Sabiduría divina, no deberá ser conducido a la admiración de su omnipotente Arquitecto?» (N. COPÉRNICO). «Cultivar la astronomía significa rebuscar los pensamientos de Dios» (J. KEPLER). «Mi último y más encumbrado conocimiento es que la maravillosa organización y armonía del universo sólo pudo haber existido según el plan de un Ser omnisciente y omnipotente» (I. NEWTON). «Un poco de ciencia nos aleja de Dios, mucha nos conduce a Él» (A.L. CAUCHY). «Yo nunca negué la existencia de Dios, y creo que la teoría de la evolución se armoniza perfectamente con la fe en Dios: La imposibilidad de probar y comprender, que tanto el magnífico y maravillosísimo universo como el hombre se deban al acaso, me parece el ar-

14. San Buenaventura, Itinerario..., I 1,2. 15. M. Schmaus, o.c., I 206. 16. Conc. Vat. II, Const. DV 3.6= Conc. Vat. I, Const. Dei Filius, 2: Denz. 1785. 17. San Juan de la Cruz, Poesías 5: AA.VV., «Vida y obras de San Juan de la Cruz», Madrid 101978, 395.18. Cf. H. Urs von Balthasar, El problema de Dios..., 203-210; Id., Saggi Teologici, III 254-58; W. Pannenberg, Cuestiones..., 167; Id., La Fe..., 28; W. Kasper, o.c., 18. . 19. H. Fries, Wer ist eigentlich Gott? (ed. H.J. Schultz), München 1969, 86; así también: K.H. Schelkle, o.c.; II 363; W. Kasper, o.c., 24. Sobre la relación entre la teología y la ciencia, Cf. G. Eder, Ciencias naturales y teología:SM I 745-52:749ss. infra, n. 20 (bibliogr.). También en la filosofía hodierna es central el tema sobre Dios, como lo muestra el éxito logrado por el libro de X. Zubiri: Cf. supra, n. 12 . 
gumento principal a favor de la existencia de Dios» (CH. DARWIN). «Mis estudios e investigaciones me han llevado a tener casi la fe de un labrador bretón, y no dudo que si investigase más llegaría a tener la fe de una labradora bretona», pues «la ciencia conduce al hombre a Dios» (L. PASTEUR). «Entre religión y ciencia natural no encontramos contradicción alguna, sino total concordancia precisamente en los puntos decisivos», pues aquéllas «no se excluyen - como algunos opinan y temen hoy- sino se complementan y condicionan. Dios está para los creyentes al principio, para el físico está al fin de todo pensamiento» (M. PlANK). «No es más vergonzoso rezar, que beber y respirar: El hombre necesita a Dios, como necesita agua y aire» (A. CARREL). «Declaro con orgullo que soy creyente; creo en el poder de la oración: No sólo como creyente católico sino también en cualidad de científico» (G. MARCONI). «Los resultados de la... física no están en la menor contradicción con la fe en un Poder regidor, que está tras y sobre la naturaleza... iTodo puede aparecer como una grandiosa revelación de la naturaleza, incluso al más crítico científico de la misma, ...conduciéndole a la fe en un Ordenador omnipotente, que está tras este ser lleno de sentido» (M. HARTMANN). «A todo serio investigador de la naturaleza le debe ser connatural una especie de sentimiento religioso», pues «en el universo incomprensible se revela una razón infinitamente superior. La opinión común, que yo sea ateo, es un gran error: Quien lo deduzca de mis teorías científicas, no las ha entendido en absoluto...», ya que si «la religión sin la ciencia es ciega, la ciencia sin la religión es coja» (A. EINSTEIN). «Los teólogos... conservan la única Verdad más profunda que la verdad de la ciencia, sobre la que descansa la era atómica; ellos conservan un conocimiento sobre la esencia del hombre, enraizado más profundamente que la racionalidad de la edad moderna. Y siempre de nuevo llega el momento, en que, cuando fracasa la planificación humana, hay que preguntar por esa Verdad» (C. F, von WEIZSÄCKER). «El primer trago bebido en el vaso de la ciencia natural hace a uno ateo, pero en el fondo del vaso espera Dios» (W. HEISENBERG). «Sobre todo está la gloria de Dios, que creó el grande universo, penetrado y escrutado diariamente por el hombre y su ciencia con gran reverencia». Pues «la opinión común, que quienes vivimos en la era de los viajes espaciales sabemos tanto sobre la naturaleza que no necesitamos creer en Dios, no se puede justificar con nada: ¡Hasta el presente, con cada nueva respuesta la ciencia descubre al menos tres nuevas preguntas!». Por lo demás, «sólo una renovada fe en Dios puede crear las transformaciones, que salven a nuestro mundo de la catástrofe: ¡Ciencia y religión se hermanan, no se contraponen!» (W. von BRAUN) ${ }^{20}$.

20. Cf. E. Frankenberger, Gottbekenntnisse grosser Naturforscher, Leutesdorf 1982, 7-28.

Numerosos testimonios, al respecto, sobre 432 científicos del s. XIX y principios del s. XX nos ofrece la vasta y bien documentada monografía de A. Eymien (La part des croyants dans le progrès de la science au XIX é siècle, I-II, Paris 1928.1935), concluyendo sus análisis sobre la obra y pensamiento de aquéllos (II 274-90): Entre los 398 científicos, cuyas ideas religiosas conocemos, sólo 16 fueron ateos y 367 creyentes, -muchos de ellos cristianos y católicos practicantes-, entre los cuales 150 fueron autores de grandes descubrimientos y teorías científicas (II 274-79), siendo por tanto la simple estadística del extraordinario número de científicos creyentes una prueba de que entre razón y fe no existe incompatibilidad ni conflicto alguno y si «hay afinidad entre ciencia 


práctico del universo y del hombre, sino también de «la sabiduría teológica» o pedagogía salvífica y revelación de Dios a su pueblo ${ }^{45}$.

b) Esa reiterada y fragmentaria autorrevelación de Dios en la historia de Israel, sin embargo, culminó con la Encarnación o envío de su Hijo al mundo, para revelarlo totalmente a los hombres o lograr, mediante sus palabras y obras mesiánicas, hacerles evidente su presencia salvífica en medio de ellos ${ }^{46}$. Sin duda que la existencia de Dios fue para JESÚs DE NAZARET tan evidente como para un niño la de su padre: Experimentó a Dios como Padre propio quien tuvo clarividente conciencia de ser Hijo natural suyo y poder, por ello, invocarle "Abbá» = Papá ${ }^{47}$. Como Hijo de Dios encarnado, sin embargo, será en adelante «Cristo Jesús, único Mediador entre Dios y los hombres» así como «el Camino» por el que éstos pueden conocer «la Verdad» o plenitud de la revelación de Dios y conseguir «la Vida» eterna ${ }^{48}$, el único medio de «ir al Padre» o "conocer» plenamente al «único Dios verdadero» ${ }^{49}$. Por medio de Él, sin duda, llegó MARÍA - su madre - al pleno conocimiento de Dios, cuya existencia le fue tan evidente como la presencia del Hijo «en su seno», por «gracia» de Quien «miró la humildad de su sierva» ${ }^{50}$. También PABLO conoció en pleno a Dios, mediante «la revelación» que, a raíz de su conversión, le hizo Él de «su Hijo», irradiando entonces en su corazón «el conocimiento de la gloria de Dios, que está en Cristo Jesús» ${ }^{51}$. Y los primeros CRISTIANOS, que antes de su conversión adoraban a «los ídolos» o daban culto «al [verdadero] Dios desconocido» por los hombres e ignorado por «la sabiduría del mundo" ${ }^{52}$, llegaron al conocimiento del "Dios vivo y verdadero» mediante el anuncio de Jesús crucificado y resucitado, «Sabiduría de Dios» ${ }^{53}$, conociendo aquéllos al «Dios-es-Amor» por la personal experiencia de Quien manifestó su amor enviando «su único Hijo al mundo... como propiciación de nuestros pecados», pues «el Hijo de Dios ha venido y nos dio inteligencia, para que conozcamos al Verdadero" ${ }^{54}$. Cristo resucitado, presente en su Iglesia ${ }^{55}$, es pues el único medio dado al hombre, para conocer al genuino rostro de Dios.

3) Frente a esa evidencia - natural y sobrenatural- de la existencia de Dios, sin embargo, se alza no menos patente la realidad antigua y hodierna del ateísmo, no sólo teórico sino también práctico ${ }^{56}$. Pues desde los Sofistas grie-

45. Cf. G. von Rad, Teología del AT, I 508-54; Id., La Sapienza in Israele (trad. ital.), Roma 1975, 109-252; A. Barucq, Dieu. 46. Hebr 1,1-3; 2Cor 1,20; 3,12-4,6; Jn 1,1-18; 14,8-11; Cf. Conc. Vat. II, Const. DV 4; R. Latourelle, o.c., 435-54. 47. Lc 2,49; 10,21-22 (=Mt 11,25-27);

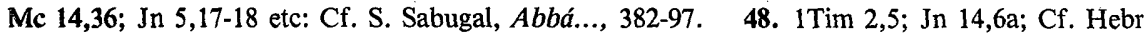
10,19-20. 49. Jn 14,6b-8; 17,3; Cf. 1,18. 50. Lc 1,26-38.47-48. 51. Gál 1,16;2Cor 4,6: Cf. S. Sabugal, La conversión de san Pablo, Barcelona 1976, 12-18.31-33. 52. 1Tes 1,9; Gál 4,8; Act 17,23; 1Cor 1,21; Cf. Act 14,15. 53. Gál 4,9; Act 17,23-31; 10,34-43; 1Tes 1,9; 1Cor 1,23-25; 2Cor 2,14; 4,6. 54. 1 Jn 4,8-16 (Cf. Rm 5,5-8); 5,20. 55. Mt 28,20; 18,20; Jn 14,15-18. 56. Cf. a este respecto: H. de Lubac, Le drame de l'humanisme athée, Paris ${ }^{3} 1945$; M. Schmaus, o.c., I 217-33; G. Regamey-K. Rahner, Atheismus: LThK I 982-90; J. Lacroix, El sentido del ateísmo moderno, Barcelona 1963; G. Girardi (dir.), El ateísmo contemporáneo, I-V, Madrid 1971-73; K. Rahner, Atelsmo: SM I 456-69 (bibliogr.); L. Scheffczyk, El problema teológico del ateísmo: Ib., II 
gos (s.V a.c.), que negaron la posibilidad de saber «si los dioses existen o no» (Protágoras) y afirmaron que "el Ser no existe» (Georgias) o que «los dioses son invenciones humanas» (Cricias) ${ }^{57}$, pasando por el ateísmo moderno de quienes aseguran que «Dios ha muerto» ( $F$. Nietzsche) o que su misma «idea es contradictoria» $(J . P \text {. Sartre })^{58}$, hasta la reciente y fugaz teología americana sobre «la muerte de Dios» o incapacidad del hombre hodierno para creer en Él ${ }^{59}$, la historia del pensamiento religioso y filosófico muestra, «que de hecho existe un ateísmo teórico ${ }^{60}$. Más aún: éste no constituye hoy -como en el pasado- «un hecho insólito e individual» sino condividido por «muchos» hombres y expresado tanto a «niveles filosóficos» como en «la literatura, el arte, la interpretación de las ciencias humanas y de la historia» e, incluso, «la misma legislación civil» ${ }^{61}$. Por lo demás, a ése se suma el ateísmo práctico de los creyentes, que viven como si Dios no existiera y dan culto en realidad a los ídolos - poder, dinero, trabajo, sexo...- de este mundo. Es, pues, un hecho indiscutible la existencia hodierna de muchos ateos teóricos y prácticos, constituyendo «este ateísmo uno de los fenómenos más graves de nuestro tiempo» ${ }^{62}$. Entre sus "varias causas» hay que señalar, sin duda, la concepción materialista del mundo así como la desmesurada confianza en el progreso técnico y la divinización del hombre ${ }^{63}$. A ellas, sin embargo, se suman otras: No sólo la deficiente predicación cristiana sobre Dios así como la escasa presencia de testimonios vivos que, con su vida según el Evangelio, despierten en los incrédulos la fe en la existencia del Dios verdadero, sino también - y sobre todo- el antitestimonio de muchos creyentes incrédulos, que «han velado más bien que revelado el genuino rostro de Dios» ${ }^{64}$. ¿Los remedios a ese grave mal de nuestro tiempo? Siguen teniendo valor y actualidad, ciertamente, las tradicionales pruebas sobre la existencia de Dios ${ }^{65}$. Pero la eficacia de esos argumentos está hoy condicionada decisivamente por «la integridad de vida de la Iglesia y de sus miembros» ${ }^{66}$ : Por el vivo e irrefutable testimonio de és-

\footnotetext{
302-4; Ch. Chabanis, Dieu existe-t-il? Non, répondent..., Paris 1973; G. Siewerth-J. Gómez Cafarena, Ateísmo: CFT I 139-54; S. Verges, Dios y el hombre. La creación, Madrid 1980, 42-73; M.F. Sciacca (dir.), o.c. (supra, n. 2); W. Kasper, o.c., 29-91. 57. Cf. M.F. Sciacca, o.c., I 11-14. 58. Cf. M.F. Sciacca, o.c., II 382-87.735-38. 59. Th. Altizer-W. Hamilton, La teología radical y de la muerte de Dios, Barcelona 1967; G. Vahanian, La muerte de Dios. La cultura de nuestra era postcristiana, Barcelona 1968; Id., Ningún otro Dios, Madrid 1972; J. Bishop, Los teólogos de la muerte de Dios, Barcelona 1968. A este respecto, Cf.: H. Fries-R. Stählin, Gott ist tot?, München 1968; J. Gómez Cafarena, a.c., 152s; S. Verges, o.c., 74-138. 60. K. Rahner, a.c., [=SM], 458; Cf. Id., a.c., [=LThK], 984. 61. Conc. Vat., Const. GS 7.19; Cf. Decr. AG 10. 62. Conc. Vat. II, Const. GS 19; así también Pablo VI, Enc. ES 93. Sobre el estudio del ateísmo en el Conc. Vat. II, Cf.: K. Rahner, a.c. [=SM], 459-61; J. Gómez Cafarena, a.c., 149-52. 63. Cf. Conc. Vat. II, Const. GS 19-20. 64. Conc. Vat. II, Const. GS 19. 65. Cf. supra, 226s, nn. 11-14. Esas pruebas no sólo «resuelven las dificultades y objeciones, que podrían oponerse a la convicción de la existencia de Dios», sino también «contribuyen a justificar las convicciones de los creyentes» en Él (M. Schmaus, o.c., I 206). De ahí que el hodierno Magisterio de la Iglesia proponga como primer «remedio del ateísmo... la exposición adecuada de la doctrina» sobre Dios: Conc. Vat. II, Const. GS 21. 66. Conc. Vat. II, Const. GS 21.
} 
tos con los dos signos eficaces de la fe en Dios para todo incrédulo, como son el mutuo amor en la dimensión de la Cruz y la mutua unidad en la caridad ${ }^{67}$, con los que manifiestan la existencia y presencia del «Dios-es-Amor» entre los hombres y en el mundo. Éste necesita, pues, hoy esos testigos del Amor, que con la irresistible fuerza de su testimonio no sólo convenzan eficazmente a los ateos hodiernos, que Dios existe, sino demuestren también - y con no menor eficacia- a los hodiernos idólatras, que existe:

\section{2. ¡UN SOLO DiOS!}

Cf.: J. HEHN, o.c., 275-80; E. STAUFFER, ThWNT III 95-105; B. BALSCHEIT, Alter und Aufkommen der biblischen Monotheismus in der israelitischen Religion (BZAW 69), Tübingen 1938; P. HEINISCH, o.c., 22-29; M. REHM, o.c., 17-22; P. VAN IMSCHOOT, o.c., I 32-42; H.H. ROWLEY, Moses und der Monotheismus: ZAW 69 (1957) 1-21; V. HAMP, Monotheismus im AT: SacPag 1 (1959) 516-21; M. SCHMAUS, o.c., I 382-94; K. RAHNER, ET I 116-21; B.W. ANDERSON, a.c., [IDB II], 427s; C.F.D. MOULE, a.c., [IDB II], 431; A. DEISSLER, a.c., [DTB], 274s; E. JACOB, o.c., 51-53; W. EICHRODT, o.c., I 201-8; M. GARCIA CORDERO, o.c., I 71112.197-220; J. HASPECKER, a.c. [CFT I], 344s; B. LANG (dir.), Der einzige Gott. Die Geburt des biblischen Monotheismus, München 1981; J. SCHNEIDER, a.c., [DTNT I], 33s.

Característica común de todas las religiones del ORIENTE ANTIGUO es el politeísmo - frecuentemente panteístico - propio del culto a varios dioses, con marcada tendencia al henotismo o culto especial a un dios considerado superior a los otros y, por ello, designado «señor de los dioses» ${ }^{68}$. También la religión de la antigua GRECIA y ROMA se caracteriza fundamentalmente por un politeísmo acentuado, _iel monoteísmo «es mengua de Dios»! —: con im-

67. In 13,34-35; 17,21. Un testimonio subrayado por el Conc. Vat. II, Const. GS 21.93; Decr. AA 8.13; Decr. AG 11-12. Ya dos decenios antes lo hizo - y con energía- H. de Lubac, o.c., 12634: Ante el drama del humanismo ateo, «el cristianismo... es la religión del amor» y, por tanto, «no tendrá jamás eficacia real... ni hará conquistas reales más que... con la fuerza de la caridad» (133s); así también: K. Rahner, a.c., [=SM], 468; G. Siewerth, a.c., 148. 68. Cf.: J. Hẻhn, o.c., 1-213; P. Heinisch, o.c., 27-29; H. Hees, Der Götterglaube im alten Aegypten, Innsbruck 1941, 187-299; H. Bonnet, Reallexikon der ägyptischen Religionsgeschichte, Berlin 1952, 218-54; M. Smith, The common theology in Ancient Near East: JBL 71 (1952) 135-47; S.H. Hooke, Babilonian and assyrian Religion, Oxford 1962, 12-27; M. García Cordero, o.c., 217-19; C.J. Bleeker, La religión del antiguo Egipto: "Historia Religionum. Manual de historia de las religiones» (dir. C.J. Bleeker-G. Widengren), I, Madrid 1976, 51-118: 62-81; W.H. Ph. Römer, La religión de la antigua Mesopotamia: Ib., 123-91:130-45; H. Ringren, La religión de la antigua Siria: Ib., 197222:200-211; H. Otten, La religión de los Hititas: Ib., 313-18:313-15; J. Duchesne-Guillemin, La religión del antiguo Irán: Ib., 319-70:326-44. Ya ca. el 2500 a C. el politeísmo de la religiosidad practicada en el imperio de Ebla acusa una clara tendencia al henotismo: Cf. P. Matthiae, Ebla, Torino 1977, 203-206; G. Pettinato, Ebla, Milano 1979, 265-87:264-70. 
plicaciones panteísticas, en el que la supremacía o especial veneración de Zeus y de Júpiter, respectivamente, acusa una tendencia henoteísta ${ }^{69}$.

Marcadamente diversa es, sin embargo, la religión de ISRAEL. Es cierto que, a lo largo de su historia, la idea de Dios se fue perfeccionando ${ }^{70}$ : Desde el «Dios familiar» de los patriarcas ${ }^{71}$ y el monoteísmo monolátrico del período mosaico (Éx 20,2-3) ${ }^{72}$, hasta el monoteísmo estricto de los Profetas, quienes incansablemente anuncian a Jahveh como el único Dios ${ }^{73} \mathrm{y}$, en marcada polémica antiidolátrica ${ }^{74}$, ridiculizan a los ídolos ${ }^{75}$ y afirman sin ambages que éstos «no son Dios» ${ }^{76}$, recordando enérgicamente («ishemá!») a Israel: « ¿El Señor, nuestro Dios, es único!» ${ }^{77}$. Este monoteísmo profético, que al nivel de la actual redacción literaria recorre - desde Gén 1,1 a Sab 19,22- todo el AT, caracteriza profundamente la religiosidad israelítica y la distingue netamente de toda religiosidad antigua, siendo un fenómeno único y nuevo - humanamente inexplicable - en la historia de las religiones ${ }^{78}$. Y tuvo continuidad. Pues en contraposición al politeísmo de la religiosidad helenística ${ }^{79}$, el JUDAÍSMO antiguo heredó, conservó fielmente y propagó con valentía entre los pueblos el monoteísmo veterotestamentario ${ }^{80}$ : No sólo cristalizó éste en el «Shemá» o confesión de fe monoteística, recitada dos veces diariamente por

69. Cf.: H. Kleinknecht, ThWNT III 65-79; W. Jäger, Theologie der frühen griechischen Denker, Berlin 1953: K. Rahner, El concepto griego de Dios: ET I 105-7; W. Pannenberg, Cuestiones..., 96-106; A.W'. \(kins, Religión griega: «Historia Religionum», I 371-432:381-400; R. Schilling, Religión romana: Ih., 435-82:454-68; K.H. Schelkle, Teología del NT, II, Barcelona 1977, 379-82. 70. Cf. M. García Cordero, o.c., I 66-117; C. Widengren, Religión judeoisraelitica: «Historia Religionum», I 223-311:325ss. 71. Cf. A. Alt, Der Gott der Väter, Stuttgart 1929; M. García Cordero, o.c., I 71-82; E. de Vaux, Historia antigua de Israel, I, Madrid 1975, 273-80. 72. Cf. P. van Imschoot, o.c., I 35s; E. Jacob, o.c., 51s; M. García Cordero, o.c., I $82-92$. 73. Os 12,$10 ; 13,4$; Is $37,16.20 ;$ Dt 4,$35 ; 6,4 ; 32,39 ; 1 \operatorname{Re} 8,60 ; 2 \operatorname{Re} 5,15$; Is $41,21-29 ; 43,10-12 ; 44,6-8 ; 45,3.5-6.14-15.18 .20-22 ; 46,5-7.9 ; 48,11$; Mal 2,10; Jl 2,27; Dan 2,28; 3,29.45; 14,41 etc. A este respecto, Cf. M. García Cordero, o.c., I 106-112. 74. Cf. A. Gelin, Idoles. Idôlatrie: DBS IV 169-87:184ss (bibliogr.). 75. Os 9,10; Is 29,4; 44,9-20; 46,1-2; Jer 2,5.9.11.28; 8,5; 10,1-16; 16,18-19; Bar 6,7-7,72; Dt 32,37-39; así también Sab 13,10-14,1.15-21; 15,4-19. A este respecto, Cf.: H.D. Preuss, Verspottung fremden Religionem im AT, Stuttgart 1971; M. Gilbert, La critique des dieux dans le Livre de la Sagesse (Sab 13-15), Rome 1973.76. Os 8,6; Bar 6,14.22.28.39.44.51.55.64.68. Jahveh es, por el contrario, «un Dios grande... sobre todos los dioses» (Sal 95,3) así como «el Altísimo... sobre todos» ellos (Sal 97,4) y, más aún, «el Dios de los dioses»: Dt 10,17; Jos 22,22; Dan 2,47.90; Sal 50,1; 136,2. 77. Dt 6,4; Cf. 2Sam 7,22; 22,32; $1 \operatorname{Re} 8,23 ;$ Sal 81,9-11. 78. Así con: J. Hehn, o.c., 271ss; P. Heinisch, o.c., 22; P. van Imschoot, o.c., I 36; W. Eichrodt, o.c., I 203; J. Haspecker, a.c., 344. 79. Cf.: H. Kleikknecht, ThWNT III 74-76; G. Haufe, Religiosidad helenistica popular; «El mundo del NT» (dir. J. Leopoldt-W. Grundmann), I, Madrid 1973, 75-109:76-84 (bibliogr.); Id., Los misterios: Ib., 111 140; G. Hansen, El culto al soberano: Ib., 141-58; M.J. Vermaseren, Religiones helenísticas: «Historia Religionum», I 483-518:491-95 (bibliogr.). De ese politeísmo se hacen eco frecuente los Autores neotestamentarios: Cf. infra, n. 90 (textos). 80. Cf. a este respecto: W. Bousset-H. Gressmann, Die Religion des Judentums, Berlin 1925, 302-320; G.F. Moore, Judaism, I, Cambridge 1927, 360-67; M.J. Lagrange, Le Judaïsme avant Jésus-Christ, Paris ${ }^{3} 1931$, 341-43; J. Bonsirven, Le Judaïsme palestinien, I, Paris 1934, 149-55; E. Stauffer, ThWNT III 96-100; O. Michel, Ib., V 205s; V.H. Neufeld, The earliest christian confessions (NT TSt 5), Leiden 1963, 3441. 
todo judío piadoso ${ }^{81}$; la confesión «Dios es uno» ${ }^{82}$ significaba, en realidad, apostasía del politeísmo pagano ${ }^{83} \mathrm{y}$, por ello, no rara vez fue profesada al precio de la vida por fieles judíos, entre los cuales rabbí Aqiba (s.II d.C.), cuyo martirio soportó recitando el «Shemá» y musitando como última palabra: «iEhad $=$ Uno!» ${ }^{84}$.

El testimonio de los tres primeros evangelistas (Mc 12,28-29par) muestra, que esa confesión de fe monoteística «fue habitualmente recitada por JESÚS» ${ }^{85}$. También Él hizo, pues, suya la confesión veterotestamentaria y judaica, según la cual «el Señor, nuestro Dios, es el único Señor», a quien «se debe amar» con la totalidad del amor ${ }^{86}$. Y subrayó reiteradamente esa unicidad de Dios: Si afirmó que "sólo a Dios se debe dar culto» ${ }^{87}$, en el contexto de su mensaje central anunció y proclamó asimismo «el [único] Reinado de Dios» ${ }^{88}$, implícito por lo demás en la incompatibilidad total de «servir a Dios y al dinero» (Mt 6,24 = Lc 16,13), principal ídolo de este mundo y radicalmente contrapuesto al «único Dios verdadero» (Jn 17,3). La unicidad de Dios es, pues, «uno de los elementos centrales» de su mensaje ${ }^{89}$. Así lo reflejan los AUTORES NEOTESTAMENTARIOS: En el contexto religioso del entonces dominante politeísmo helenístico ${ }^{90}$, profesado por quienes «no conocen al Dios» yerdadero ${ }^{91}$ y dan culto a los que «no son dioses» ${ }^{92}$, los paganos son exhortados por los primeros predicadores cristianos a «abandonar estas cosas vanas [ =ídolos] y convertirse al Dios vivo» ${ }^{93}$; y, en polémica antiidolátrica ${ }^{94}$, recuerdan los Catequistas a quienes «abandonaron los ídolos para servir al Dios vivo y verdadero» ${ }^{95}$, que «no hay más Dios que uno» o que «Dios es uno» ${ }^{96} \mathrm{y}$

81. Cf. supra, 13, n. 17 (bibliogr.); S. Sabugal, Abbá..., 344-45 (bibliogr.). 82. Orac. Sib., III 11; IV 30; Filón A., De spec. leg., I 67; Fl. Josefo, Ant. Jud., IV 201; V 112 (así también varias inscripciones judaicas: Cf. E. Peterson, Eîs Theos, Göttingen 1926, 276-99; J.B. Frey, CIJ II [Roma 1952] 207.217.221). "Dios es único»: Orac. Sib., II 760; Fl. Josefo, Ant. Jud., VIII 335.337; Apoc. Abr., 17; ctc. 83. Cf. Supra. A este respecto: V.H. Neufeld, o.c., 38-41. 84. TbBer 61b. 85. S. Sabugal, $A b b a ́ . . ., 345$, n. 25; así también J. Jeremias, $A b b a$, Göttingen 1966, 74 (trad. españ., 82); Neutestamentliche Theologie, Gütersloh 1971, 128 (trad. españ., 220s). 86. Mc 12,29-30par =Dt 6,4-5. 87. Mt 4,10 (=Lc 4,8). Análoga afirmación implica su respuesta sobre «el tributo al César» (Mc 12,17par): Cf. S. Sabugal, ¿Liberación y secularización? Intento de una respuesta bíblica, Barcelona 1978; 207s. $\quad$ 88. Mc 1,15 (=Mt 4,17); Lc 4,$43 ; 11,20(=$ Mt 12,28) etc: Cf. S. Sabugal, Abbá..., 501-28. 89. K. Rahner, ET I 117. 90. Cf. supra, n. 79 (bibliogr.); Act 14,11-15; 17,16.22-23; 19,24-28; 1Tes 1,9b; Gál 4,8; 1 Cor 8,4-5; 10,14-20; Rm 1,23.25; 1Jn 5,21; Apoc 17-18. 91. 1Tes 4,5; Cf. 2Tes 1,8; 1Cor 1,21a; Gál 4,8a; Ef 2,12; 4,18; Act 17,23.30. Una ignorancia «inexcusable» moralmente, «porque habiendo conocido a Dios» por la creación o «a través de-sus obras» creadas, «no le glorificaron como a Dios» y usirvieron a la criatura en vez de al Creador» (Rm 1,20-21.23.25): Cf. K. Rahner, ET I 112s. 92. Gál 4,8. Más aún: «Los ídolos mudos» (1Cor 12,3) son «cosas vanas» (Act 14,15) o «nada en el mundo» (1Cor 8,4a; Cf. 10,19); de ahí la contraposición entre el culto a Dios y a los ídolos (2Cor 2,16; Cf. 1Cor 10,19-21), de quienes Dios es totalmente diverso (Act 17,29). Más tarde subrayará esto también san Justino, IApol., 9. 93. Act 14,15; Cf. 17,22-29. 94. Cf. 1 Cor $8,1-6 ; 10,14-22 ; 2$ Cor 2,16 etc. 95. 1 Tes 1,$9 ;$ Cf. Gál 4,8-9; 1Cor 12,2. 96. 1Cor 8,4.6; Gál 3,20; Rm 3,30; Ef 4,6; 1Tim 2,5; Sant 2,29; Cf. 4,12. Contra el polotéísmo pagano, subrayan asimismo la unicidad de Dios numerosos testimonios de la epigrafía y liturgia cristiana 
«único» ${ }^{97}$. Nada de extraño, pues, si les prohíben comunicar con el «hermano...idólatra» y les evocan el severo castigo divino reservado a los «idólatras» ${ }^{98}$, recordándoles asimismo que todo avaro es un idólatra ${ }^{99}$ y previniéndoles incansablemente contra el peligro de recaer en la pasada idolatría: « ¡No os hagáis idólatras!», «ihuid de la idolatría!», «iguardaos de los ídolos!» 100 .

Esta revelación bíblica sobre la unicidad de Dios no ha perdido actualidad. Alecciona, por el contrario, hoy como ayer a quienes profesan «creer en un solo Dios», pero en realidad sirven a uno o varios dioses de este mundo y, con ello, velan a los incrédulos el rostro del «único Dios verdadero» (Jn 17,3): A los monoteístas, que se han instalado en el compromiso de «servir a Dios y al dinero", de dar culto a Dios y al trabajo o a la cultura, a la política, al futuro de los hijos o al progreso..., incurriendo en la «idolatría de los bienes temporales» ${ }^{101}$ o dividiendo su corazón con el culto al sexo. ¿Creo realmente «en un solo Dios»? Este interrogante deberíamos formularnos, siempre que recitamos el primer artículo del Símbolo. En él confesamos asimismo, que el único Dios por naturaleza es personalmente:

\section{El Dios TRINITARIO}

Cf.: J. Lebreton, Histoire du dogme de la Trinité, I, Paris 1927, 100-547; P. HeINISCH, o.c., 74-99; G. BARDY, Trinité: DThC XV 1045-1855:1540-1702; E. STAUFFER, Theologie des NT, Stuttgart 1945, 229-31; M. SCHMAUS, o.c., I 318-78:33464; F. Prat, La théologie de saint Paul, II, Paris 1961, 157-75; C.F.D. Moule, a.c. (IDB II), 434s; J.M. DALMAU, Trinidad: EncBibl VI 1105-13; R. SCHNACKENBURG, a.c. (DTB), 294; R. SCHULTE, La preparación de la revelación trinitaria: MS II. 1, Madrid 1969, 77-116:83-104; F.J. SCHIERSE, La revelación de la Trinidad en el NT: Ib., 117-65 (bibliogr.); J. RATZINGER, Einführung..., 125-50 (trad. españ., 132-59); M. GarCía CoRDERo, o.c., II, 465-88; S. Verges-J.M. DALMAU, o.c., 64-181; K. RAHNER, Trinidad: SM VI 731-48:731-34 (bibliogr.); K.H. SCHELKLE, o.c., II 448-67; J. HASPECKER, a.c., (CFT I), 350-52; J. AUER, o.c., 178-82; W. KASPER, o.c., 295-303.

La estructura literariamente ternaria y doctrinalmente trinitaria del Símbolo muestra, que el «Dios» confesado como único se refiere tanto al «Padre» como a su «Hijo Jesucristo» y al «Espíritu Santo» ${ }^{102}$ : Tres Personas de un solo Dios.

1) El carácter personal de Dios forma parte esencial de la teología bíbli-

(Cf. E. Perterson, o.c., 1ss) así como los Apologistas (Atenágoras, Legación en favor de los cristianos, 4-10.30; San Justino, IApol., 6,1-2; 13,1-4), defendiendo éstos al cristianismo contra la acusación de ateísmo por los paganos (Cf. H. Leclercq, Accusations contre les chrétiens: DACL I 265-307:275-87). Y es que los cristianos «ante todo creen que hay un solo Dios»: Hermas, Pastor, Mand. I 1. 97. Rm 16,27; 1 Tim 1,17; 6,15; Jds 25; Apoc 15,4. 98. Cf. 1Cor 5,11; Apoc 21,8; 22,15; «no heredarán el Reino de Dios»: 1Cor 6,10; Cf. Ef 5,5. ,99. Cf. Ef 5,5; Col 3,5. 100. 1 Cor $10,7.14 ; 1$ Jn 5,21 101. Conc. Vat. II, Decr. AA 7; Cf: S. Sabugal, Liberación..., 229-32. 102 Cf. supra, 48-52. 
ca. Lo enseña ya con claridad el AT ${ }^{103}$, en el contexto de cuya teología tanto los frecuentes antropomorfismos divinos ${ }^{104}$ como los nombres propios de Dios (Cf. infra) y sus atributos tanto morales como intelectuales (Cf. infra) subrayan la personalidad de quien, por lo demás, se reveló con salvíficas gestas concretas como el Dios de la historia. Este carácter personal de Dios recorre, pues, todas las páginas de la literatura veterotestamentaria, constituyendo incluso «el rasgo esencial de las manifestaciones divinas» en el AT ${ }^{105}$. Con mayor claridad emerge la personalidad de Dios en los escritos neotestamentarios ${ }^{106}$ : El modo como sus autores hablan antropomórficamente de Él ${ }^{107}$ así como de sus atributos intelectuales y morales, propios por lo demás de Quien obra libremente la historia de Cristo y de los cristianos ${ }^{108}$ como «el Padre» de aquél y de éstos (Cf. infra), subrayan su personalidad. Para Jesús y los primeros cristianos, en efecto, Dios es una persona, a quien «el hombre puede decir tú como sólo se puede decir a uñ ser personal» ${ }^{109} \mathrm{y}$, más aún, como un niño puede decir tú a la persona de su «Abbá»= papá ${ }^{110}$, siendo por tanto para aquéllos «el carácter personal de Dios una realidad viva» ${ }^{110 a}$. ¡No única!:

2) El único Dios personal, en efecto, se ha revelado actuando salvíficamente en tres Personas, desvelando así la Personalidad trina de su ser único, o la Trinidad personal de su Unidad esencial. Es este el mysterium mysteriorum, propio y característico de la revelación cristiana, confesado por la Iglesia en todos sus Símbolos y, frente al cual, «el humilde reconocimiento de que no se sabe es el único saber verdadero» ${ }^{111}$. Pero sobre esa "docta ignorantia» nos instruven los Libros Sagrados:

a) Ya las veterotestamentarias y judaicas personificaciones de la Sabidu-

103. Cf.: E. Stauffer, ThWNT III 110s; P. van Imschoot, o.c., I 30-32; A. Deissler, a.c. (DTB), 282-84; W. Eichrodt, o.c., I 189-93; M. García Cordero, o.c., I 192s; J. Haspecker, a.c. (CFT I), 347s. 104. Cf.: P. van Imschoot, o.c., I 28-30; B.W. Anderson, a.c. (IDB II), 423s; M. García Cordero, o.c., I 193-97 (bibliogr.). 105. P. van Imschoot, o.c., I 30; así también J. Haspecker, a.c., 347. 106. Cf.: E. Stauffer, ThWNT III 111-13; K. Rahner, ET I 121-29; C.F.D. Moule, a.c. (IDB II), 432; J. Schneider, a.c. (DTNT II), 35s. 107. El Dios que alimenta y viste (Mt 6,26-30par) es semejante a «un hombre rico» (Lc 16,1-8) y financiero (Mt 25,1430par), al propietario de una viña (Mt 20,1-16) y a «un rey» (Mt 22,1-14par), a un pastor (Lc 15,4-7) y al padre de dos hijos (Lc 15,11-32; Mt 21,28-33)..., poseyendo los sentimientos humanos de la conmoción (Lc 15,20; Mt 18,27) y la alegría (Lc 15,7.10.23.32), del consuelo (2Tes 2,16; 2 Cor 1,$4 ; 7,6)$, del celo $(2$ Cor 11,2$)$ y de la ira $(\operatorname{Rm~} 1,18$; Ef 5,6$)$, sobre todo de la misericordia y del amor (Cf. K. Rahner, ET I 132): ;Dios en forma humana! 108. Jn 5,17; 1Cor 12,6; Fil 2,13 etc; Cf. K. Rahner, ET I 122-27. 109. E. Stauffer, ThWNT III 111s. 110. Cf. Mc 14,36; Mt 11,25 (=Lc 10,20); Jn 5,18 etc; Gál 4,6=Rm 8,15. 110a. K. Rahner, ET I 121. 111 J. Ratzinger, Einführung..., 125 (trad. españ., 133). De ahí que «no existe tema, donde con más facilidad se descarríe ni se investigue con mayor fatiga» (San Agustín, De Trin., I 3,5), pues, por lo demás, el ojo de la mente humana «no puede fijar su pupila en este misterio ni percibirle con claridad y distinción» (Id., o.c., XV 27,50), ya que sólo su «indemostrabilidad... puede ser demostrada filosófica y teológicamente con rigor»: M. Scheeben, Los misterios del cristianismo, Barcelona 1964, 27. 
ría divina ${ }^{112}$, del Espíritu de Dios ${ }^{113}$ y de su Palabra ${ }^{114}$ preanuncian oscura y vagamente la exístencia del misterio trinitario: El único Dios habla y actúa personificado en esas tres realidades de su ser divino, preludiendo por tanto esa triple autoteofanía personal, «formalmente y por su contenido, la doctrina neotestamentaria de la Trinidad» ${ }^{115}$.

b) Su revelación explícita y plena, sin embargo, es propia y exclusiva del NT, del que la confesión de la Trinidad divina constituye su «sustancia» ${ }^{116}$ y cuya mención recorre prácticamente todos sus escritos. Abre y cierra, en efecto, los relatos evangélicos sobre la vida y actividad salvífica de Jesús: El Hijo de Dios encarnado fue concebido «en el seno» de María «por obra del Espíritu Santo» ${ }^{117}$, el cual a raíz de su bautismo descendió sobre Quien fue proclamado entonces [por el Padre] su «Hijo amado» ${ }^{118}$, impulsándole luego «El espíritu al desierto, para ser tentado por el diablo» en calidad de «Hijo de Dios» ${ }^{119}$; victorioso de esta prueba, Jesús inició su actividad mesiánica, consciente de que «el Espíritu del Señor está sobre» Él, pues «con el Espíritu Santo le ungió» o «sigiló el Padre» y le envió tanto «a anunciar la Buena Noticia» como a realizar gestas salvíficas ${ }^{120}$, hechas éstas efectivamente por Él «mediante el Espíritu de Dios» ${ }^{121}$; antes de su muerte tranquilizó y consoló a sus discípulos con el ruego «al Padre» por el don del «Espíritu de verdad» o «el Espíritu Santo, que el Padre enviará en» su nombre, el cual, procedente «del Padre, dará testimonio» del Hijo ${ }^{122}$; con el don del «Espíritu» o «la Promesa del Pa-

112. Pruv 8,1-9,6; Eclo 14,2-15,10; 24,1-34; Sab 6,10 etc; Cf.: J. Lebreton, o.c., 122-31; P. Heinıisch, o.c., 78-86; G. Bardy, a.c., 1555-58; P. van Imschoot, o.c., I 228-32; G. Fohrer, ThWNT VII 490-92; W. Eichrodt, o.c., II 93-96; R. Schulte, a.c., 98s; A. George, Sabiduria: VTB 809s; P. Bonnard, La Sagesse personnifiée dans l'AT: «La Sagesse de l'AT» (dir. M. Gilbert), Gembloux-Leuven 1979, 117-29 (bibliogr.). Sobre la Personificación de la Sabiduría divina en el Judaísmo antiguo, Cf.: W. Bousset-H. Gressmann, o.c., 343-46; G.F. Moore, o.c., I 26467; J. Lebreton, o.c., 160-61.237-51; J. Bonsirven, o.c., I 213. 113. Gén 1,2; Sal 33,6; 104,2930; Is 11,1-2; 42,1; Ez 37,9-10 etc.; Cf.: J. Lebreton, o.c., 111-22; P. Heinisch, o.c., 86-94; G. Bardy, a.c., 1553-55; W. Bieder, ThWNT VI 363-66; R. Schulte, a.c., 99-102; W. Eichrodt, o.c., II 59-73; J. Guillet, Espíritu: VTB 298s. Sobre la personificación del Espíritu en el Judaísmo antiguo, Cf.: Str.-Bill., II 126-38; W. Bousset-H. Gressmann, o.c., 347-49; G.F. Moore, o.c., I 42122.437; J. Lebreton, o.c., 153-59; M.-J-Lagrange, o.c., 436-46; J. Bonsirven, o.c., I 214-16; E. Sjöberg, Pneuma: ThWNT VI 385s. 114. Is 55,11; Sal 107,20; 119,89; 147,15; Sab 18,14ss; etc; Cf.: J. Lebreton, o.c., 162-65; G. Bardy, a.c., 1555; O. Procksch, Logos: ThWNT IV 92-100; P. Heinisch, o.c., 94-99; W. Eichrodt, o.c., II 84-86; A. Feuillet, Palabra: VTB 633. Sobre la personificación de la Palabra en el Judaísmo antiguo, Cf.: Str-Bill, II 302-33; W. Bousset-H. Gressmann, o.c., 347; G.F. Moore, o.c., I 415-19; J. Lebreton, o.c., 162-65; M.-J. Lagrange, o.c., 452-56; J. Bonsirven, o.c., I 216s; D. Muñoz, Neophyti 1. Levítico (ed. A Díez Macho), Madrid 1971,70*-83*; Id., Dios-Palabra. Membra en los Targumin del Pentateuco, Granada 1974, espec., 631-39 (¡niega que la «membrá Jahveh» sea una hipóstasis divina!). 115. K. Rahner, a.c., 731. Así también: J. Lebreton, o.c., 111.137. 142s; P. Heinisch, o.c., 74; R. Schulte, a.c., 103s. 116. Tertuliano, Adv. Prax., 31. Los Padres de la Iglesia subrayan con razón la novedad neotestamentaria de esa revelación trinitaria de Dios (Cf. G. Bardy, a.c., 1546s): ¡Sólo «en el tiempo de la gracia fue revelado por el mismo Hijo de Dios el misterio de la Trinidad»!: Sto. Tomás A., Sum. Theol., II-II 174,6. 117. Lc 1,30-35; Mt 1,18-23. 118. Mc 1,9-11par; Cf. Jn 1,33-34. 119. Mt 4,1-11 par. 120. Lc 4,18-19; Act 10,38 ; Jn 6,27 b. 121. Mt $12,28=$ Lc 1i,20. 122. Jn $14,16-17.25-26 ; 15,26-27$; Cf. $16,5-8.13-14$. 
dre» les fortaleció, en efecto, el Hijo resucitado ${ }^{123}$, dándoles «el Espíritu Santo» y enviándoles - «como el Padre le envió»- al mundo, para hacer «discípulos suyos a todos los pueblos y bautizarles en el nombre del Padre y del Hijo y del Espíritu Santo» ${ }^{124}$. Nada de extraño, pues, si casi todos los restantes escritos neotestamentarios se hacen reiterado eco de las tres divinas Personas ${ }^{125}$, especificando también ocasionalmente los autores de aquéllos su respectiva obra salvífica en los fieles: Elegidos éstos por «Dios... para la salvación, mediante la acción santificadora del Espíritu», fueron por aquél llamados para "conseguir la gloria de nuestro Señor Jesucristo» ${ }^{126}$, pues «la bondad de Dios... nos salvó... mediante el baño de regeneración y de renovación del Espíritu Santo, que Él derramó profusamente sobre nosotros mediante Jesucristo nuestro salvador», ya que «el amor de Dios fue derramado en nuestros corazones por el Espíritu Santo, que nos dio» tras «haber sido reconciliados con Dios por la muerte de su Hijo» ${ }^{127}$; por lo demás, los regenerados y reconciliados fueron galardonados asimismo por las tres divinas Personas con carismas o dones, pues «uno mismo es el Espíritu» así como «el Señor» y «el Dios» que se los otorgó, siendo por ello exhortados a «conservar la unidad del Espíritu con el vínculo de la paz», ya que, como hay «un solo Espíritu» y «un solo Señor», también existe «un solo Dios y Padre de todos» ${ }^{128}$; se comprende, pues, el ruego del Apóstol «al Padre», para que les conceda ser «vigorosamente fortalecidos por la acción del Espíritu Santo» y alabar «al Señor, dando gracias continuamente y por todo a Dios Padre, en nombre de nuestro Señor Jesucristo» ${ }^{129}$. Una alabanza propia, por lo demás, de quienes, «guiados por el Espíritu de Dios, son hijos de Dios, pues» recibieron «el Espíritu de filiación, que les hace gritar: ¡Abbá, Padre!», dando así «testimonio» de su filiación divina «el mismo Espíritu» ${ }^{130}$, que «habita en» la Comunidad de los fieles como en «un templo santo» ${ }^{131} \mathrm{y}$, asimismo, mora - junto con el Padre y el Hijo- «en los corazones de aquellos, cuyo «cuerpo es santuario del Espíritu Santo»" ${ }^{132}$.

123. Lc 24,49 ; Act $1,4-5 ; 2,1-4.33$. 124. Jn $20,21-22$; Mt 28,19 125. Cf. 1 Tes $1,6-8$; 4,2-8; 5,18-19; 2Tes 2,13-14; Gál 3,1-5.11-14; 4,6; 5,21-25; 1Cor 2,6-16; 6,11.15-20; 12,3-6; 2Cor $1,21-22 ; 3,3-6.10-17 ; 4,13-14 ; 5,5-8 ; 13,13 ; \mathrm{Rm} 1,1-7 ; 5,1-5 ; 8,2-4.8-9.11 .14-16.20-30 ; 14,17-18$; 15,16-19; Ef 1,3-13.17; 2,18-22; 3,5-7.14-17; 4,4-6.30-32; 5,18-20; Fil 3,3; Col 1,6-8; Tit 3,4-6; Hebr 2,2-4; 6,4-6; 9,14; 10,20-21; 1Pe 1,1-2; 4,14; 1 Jn 3,23-24; 4,11-16; Jds 20-21; Apoc 22,16-21. Sólo en el s. II fue usado el vocablo «Trinidad» por Teófilo A. (A Autólico, II 15: trías) y luego por Tertuliano (De pud., 21: trinitas). Sobre el testimonio de los Padres de los s. I-II acerca de la Trinidad, Cf. A. Harnack, Materialien..., 369 (textos); G. Bardy, a.c., 1605-25; G.L. Prestige, o.c., 76-96. 126. 2Tes 2,13-14; Cf. 1Pe 1,1-2. 127. Tit 3,4-6; Rm 5,5.10. 128. 1Cor 12,4-6; Ef 4,3-6; Cf. Hebr 2,3-4. 129. Ef $3,14-17$; 5,18-20. 130. Rm 8,14-16; Cf. Gál 4,6. 131. 1Cor 3,16; Ef 2,21-22. 132. Cf. 1 Cor 6,19; 2 Cor 1,21-22 [=5,5; Ef 1,13; 4,30]; Rm 5,5; 8,11a; Ef 3,17; Jn 14,23. Cf. a este respecto: P. Galtier, L'inhabitation en nous des Trois Personnes, Paris ${ }^{2} 1950,11-$ 14; R. Moretti, Inhabitation: DS VII 1735-57:1739-45 (bibliogr.). Para el desarrollo teológico y experiencia mística de esta verdad cristiana, Cf.: M. Scheeben, Los misterios del cristianismo, 166-95; Id., Las maravillas de la gracia divina, Madrid 1978, 99-121; P. Galtier, o.c., 15ss; V. Rodríguez, Inhabitación de la SS. Trinidad en el alma en gracia: CTom 86 (1959) 65-115; M. Flick-Z. Alszeghy, Il Vangelo della grazia, Roma 1964, 454-98.530-92; R. Moretti, a.c., 1745ss; G.M. Bertrand, Expérience mystique de l'inhabitation: Ib., 1757-67; H. Mühlen, El Espíritu Santo en la Iglesia, Salamanca $1974,72-73.467 \mathrm{~s}$. 
¡El Dios uno y personalmente trino en nosotros!: Esto confesamos también, al decir «creo en Dios». Lo que exige de nosotros no sólo abstenernos de «contristar al Espíritu Santo» (Ef 4,30) y, por el contrario, «glorificar a Dios en nuestro cuerpo» (1Cor 6,20$)$, of reciéndole por medio suyo la «víctima viva, santa y agradable» de aquel "culto espiritual» que consiste en «distinguir cuál es la voluntad de Dios» y cumplirla (Rm 12,1-2), sino también entretenernos con frecuencia en diálogo contemplativo con los tres Huéspedes divinos, que se han dignado morar en nosotros como templos vivos del único Dios. Nuestra confesión de fe, por lo demás, precisa que éste es:

\section{EL «PADRE OMNIPOTENTE»}

Cf.: R. KITTEL, $A b b a ́$ : ThWNT I 4-6; G. QUELL-G. SCHRENK, Patér: Ib., III 946-1016; J. Bonsirven, Théologie du NT, Paris 1954, 41-54; J. Jeremias, $A b$ $b a$, Göttingen 1966, 15-67 (trad. españ., 17-73); A. STÖGER, Padre: DTB 737-43: 739ss; P. TERnANT, Padres y Padre: VTB 623-30:626ss; G. FoHRER-E. SCHWEIZER, Huiós: ThWNT VIII 340-95; W. MARCHEL, Abbá Père. La prière du Christ et des chrétiens (AB 19A), Rome 21971; M. GARCÍA CORDERO, o.c., II 373-402; O. Hofius, Padre: DTNT III 242-48; S. SABUGAL, Abbá... La Oración del Señor, Madrid 1985, 366-424 (bibliogr.). Más bibliografía, infra, nn. 138.143.145. Sobre «Dios Padre» en la historia de los dogmas, en la Patrística y en la reflexión teológica, Cf. J. AlFaro, Dios Padre: CFT I 353-61 (bibliogr.).

Los introductorios análisis sobre la estructura del Símbolo han mostrado, que la paternidad de Dios constituye el centro focal de la inicial confesión teológica ${ }^{132 a}$. ¿Qué significa exactamente la fe cristiana en Dios, confesado como «Padre»?

1. Entre los nombres divinos aplicados por el Antiguo Testamento a Dios ${ }^{133}$ figuran «El» = el Jefe ${ }^{134} \mathrm{y}$, más frecuentemente, «Elohim» = el Dios único ${ }^{135}$, designando «Jahveh» (LXX: «Kýrios») ${ }^{136}$ a quien se autorreveló el único salvadoramente Existente ${ }^{137}$. Del todo parco, sin embargo, es el nombre «Padre» ${ }^{138}$, usado para designar a Dios ante todo como Padre de Israel, a

132a. Cf. supra, 51s. 133. Cf.: J. Hehn, o.c., 213-71; G. Quell, ThWNT III 79-90.1056-80; P. Heinisch, o.c., 12-19; M. Rehm, o.c., 9-16; P. van Imschoot, o.c., I 7-28; B.W. Anderson, God, names of: IDB II 407-17; W. Eichrodt, o.c., I 163-88; M. García Cordero, o.c., I 33-66. 134 Cf.: P. van Imschoot, o.c., I 8-9; B.W. Anderson, a.c., 411s; W. Eichrodt, o.c., I 163-65; M. García Cordero, o.c., I 34-38; R. de Vaux, Historia, I 273-80. 135. Cf.: P. van Imschoot, o.c., I 1214; B.W. Anderson, a.c., 413s; W. Eichrodt, o.c., I 169-71; M. García Cordero, o.c., 39-41. Los LXX traducen «Elohim» por ho Theós, nombre que en el NT designa casi exclusivamente al Padre (Cf. K. Rahner, ET I 144-67), siendo aplicado asimismo por varios textos (Rm 9,4-5; Tit 2,13; Jn 1,1.18; 10,34; 20,29; 1Jn 5,20) al Hijo: Cf. E. Stauffer, ThWNT III 105-7; J. Schneider, a.c. (DTNT II), 39. 136. Cf.: J. Hehn, o.c., 213-30; P. van Imschoot, o.c., I 14-20; R. Mayer, Der Gottesname Jahve im Lichte der neuersten Forschung: BZ 2 (1958) 26-53; B.W. Anderson, a.c., 409-11; W. Eichrodt, o.c., I 171-77; II 48-52; M. García Cordero, o.c., I 41-56; R. de Vaux, Historia, I 330-47. 137. Ese sentido tiene Éx 3,14; Cf.: G. Quell, ThWNT III 1069-72; P. van Imschoot, o.c., I 15-17; B.W. Anderson, a.c., 410s; W. Eichrodt, o.c., I 173s; M. García Cordero, o.c., I 43-53 R. de Vaux, o.c., I 339-46. 138. M.-J. Lagrange, La paternité de Dieu dans l'AT: RB 5 (1908) 481-99; G. Quell, ThWNT V 959-74; G. Forhrer, ThWNT VIII 347-55; L. Moraldi, La paternità di Dio nell'AT: RBItal 7 (1959) 44-56; J. Jeremias, o.c., 15-19 (trad. españ., 19-23); 
quien por la elección gratuita y, sobre todo, por la alianza se ligó con un amor paterno, salvándole, corrigiéndole y perdonándole asimismo con solicitud paternal ${ }^{139}$; Dios es también - por su gratuita elección y protección paternaPadre del monarca ${ }^{140} \mathrm{y}$, de un modo particularmente íntimo, lo será del Rey mesiánico ${ }^{141}$, siendo asimismo - por su providente solicitud y paternal protección- Padre del justo israelita ${ }^{142}$. Del todo parco es asimismo el uso del nombre divino «Padre» por la literatura del Judaísmo antiguo: Ése ignoró la invocación divina «Abbá», - propia de un hijo para con su padre y apelativo cortés dirigido a personas respetables-, designando colectiva e individualmente «Padre» a Dios, por su autoridad así como por su misericordiosa disponibilidad a la protección y al perdón ${ }^{143}$. La literatura veterotestamentaria y judaica hizo, pues, parco uso de ese nombre divino, por ser misión esencial de Israel y del Judaísmo creer y confesar al único Dios. Esa fe y confesión heredó Jesús así como los autores del Nuevo Testamento (Cf. supra), en cuyos escritos, sin embargo, «Padre» devino el frecuente $[=245 \mathrm{x}]$ y más característico nombre de Dios ${ }^{144}$, así designado ${ }^{145}$ como Autor de la filiación divina de Cristo y de los cristianos:

1) Que Dios es Padre natural de Jesús lo atestiguan, sin ambages, todos los relatos evangélicos: Si Él invocó familiarmente a Dios como «Abbá» (Mc $14,36)$ en toda sus oraciones ${ }^{146}$, fue sin duda por su autoconciencia de que «el Padre» ${ }^{147}$ es $« s u^{4 i}$ Padre» ${ }^{148}$, en el sentido «propio de su natural filiación divi-

W. Marchel, o.c., 23-84; H. Ringren, $A b$ : DTAT I 1-19; E. Jeni, $A b$ : Padre: DTMAT I 35-57:53ss; M. García Cordero, o.c., II 373-75; S. Sabugal, o.c., 369-74 (bibliogr.).

139. Dt 32,$6 ;$ Is 63,$16 ; 64,7$; Jer 31,$9 ;$ Mal 1,6; 2,10: Cf. S. Sabugal, o.c., 370s. 140. 2Sam 7,14 ; Sal 89,27 ; Cf. 2,7 . 141. 1Crón 17,$13 ; 22,10 ; 28,16$; Cf. Sal 2,7 ; Is 9,5: S. Sabugal, o.c., 372s. 142. Eclo 23,1.4; 51,10 [TH]; Sab 2,16; 14,3; Cf. Sal 103,13; Prov 3,12: S. Sabugal, o.c., 373. 143. Cf. J. Jeremias, o.c., 19-33 (trad. españ., 23-35); S. Sabugal, o.c., 374-78 (bibliogr.). 144. Cf.: R. Kittel, a.c., 5-6; G. Schrenk a.c., 981-1016; H.F.D. Sparks, The doctrine of the divine Fatherhood in the Gospels: "Studies in the Gospels» (Mem. R.H. Lightfoot), Oxford 1955, 241-62; H.W. Montefiore, God as Father in the Synoptic Gospels: NTSt 3 (1956) 31-46; A. George, Le Père et le Fils dans les Évangiles Synoptiques: LumVie 29 (1956) 603-16; J. Giblet, Jésus et «le Père» dans le Quatrième Évangile: «l'Évangile de Jean» (RechB II), Louvain 1958, 111-30; K. Rahner, ET I 144-67:163ss; T.W. Manson, The teaching of Jesus, Cambridge 1963, 93-115; X. Léon-Dufour, Les Évangiles et l'histoire de Jésus, Paris 1963, 379-414; B.M. van Iersel, «Der Sohn» in den synoptischen Jesusworten (Suppl. NT 3), Leiden 1964, 93-116; J. Jeremias, o.c., 33-67 (trad. españ., 37-73); F. Amiot, L'enseignement de saint. Paul, Paris 1968, 89-91.209-12; E. Schweizer, a.c., 364-95; M. García Cordero, o.c., II 377-402; W. Marchel, o.c., 99-235; R. Schnackenburg, Das Johannesevangelium, II (Herders ThKNT IV. 2), Freiburg 1971, 150-78 (trad. españ., 158-75); K.H. Schelkle, o.c., II 297-311; M. Wellanickal, The divine sonship of Christian in the Johannine Writings (AB 72), Rome 1977; O. Michel, Patér: EWNT III 125-35. 145. «Dios Padre» (1Tes 1,1; 2Tes 1,2; Gál 1,1; 1Cor 15,24; Ef 6,23; Fil 2,11; 1 Tim 1,2; 2Tim 1,2; Tit 1,4; 1Pe 1,2; Sant 1,27; Jds 1; Cf. 1Cor 8,6; 2Cor 1,3; 11,31; Rm 15,6; Ef 1,3; $1 \mathrm{Pe} 1,3 ;$ Jn 20,17), «el Dios Padre» (Col 3,17), «Dios y Padre» (Ef 4,6; 5,20), «Dios nuestro Padre» (2Tes 1,1; 1 Cor 1,3; 2 Cor 1,2; Rm 1,7; Ef 1,2; Fil 1,2; Col 1,2), «nuestro Dios y Padré»: 1Tes 1,3; 3,11; 2Tes 2,16; Gál 1,4; Fil 4,20. Para el significado teológico del nombre divino «Padre» en esos textos, Cf. S. Sabugal, $A b b a ́ \ldots$, 250-51.262-66. 146. Cf. J. Jeremias, o.c., 56-64 (träd. españ., 62-71); S. Sabugal, o.c., 382-86.392-94. 147. Cf. J. Jeremias, o.c., 39-41 (trad. españ., 43-46); S. Sabugal, o.c., 389-91. 148. J. Jeremias, o.c., 46-54 (trad. españ., 52-60); S. Sabugal, o.c., 391-94. 
na» ${ }^{149}$; exclusiva ésta, por lo demás, del «unigénito Hijo de Dios» ${ }^{150}$, venido al mundo para hacer la voluntad del Padre (Hebr 10,5-9), que cumplió hasta el final ${ }^{151}$, permaneciendo unido a Él en la unidad y recíproca inmanencia ${ }^{152}$ de aquel amor ${ }^{153}$, manifestado por el Padre «al mundo» pecador con el don de «su Hijo» para salvarle ${ }^{154}$. «El Padre de nuestro Señor Jesucristo» ${ }^{155}$ es, pues, esencialmente «el Padre misericordiosísimo» para con todos los hombres, «de quien todo procede y para quien somos» ${ }^{156}$, pues a Él se debe el universal plan salvífico realizado en Cristo ${ }^{157} \mathrm{y}$, por tanto, «la filiación» divina de los cristianos ${ }^{158}$.

2) Éstos, en efecto, pueden llamar a Dios «nuestro Padre» ${ }^{159}$. Y Jesús fue consciente de ello, al definir mediante la expresión «vuestro Padre» la relación exclusiva de sus discípulos con el Dios providente, ilimitadamente misericordioso y dispuesto siempre al perdón ${ }^{160}$, no sin otorgarles el exclusivo privilegio de invocarle - como Él lo hizo- «Abbá» ${ }^{161}$ : ¡Eran realmente hijos de Dios! Así lo entendieron los Autores neotestamentarios ${ }^{162}$, precisando Pablo que esa filiación divina es gratuito don del mismo Dios, otorgado a los fieles mediante «el Espíritu de su Hijo» y, con ello, el derecho a invocarle « $; A b b a ́$, Padre!» ${ }^{163}$. Aquel don es, pues, la prueba manifiesta del «amor, que ha tenido el Padre» a los que son sus hijos queridos o «amados del Padre» ${ }^{164}$. Cuya voluntad, por tanto, deben cumplir ${ }^{165}$, para ser hermanos de Jesús y entrar en el Reino del Padre ${ }^{166}$, de quien aquéllos reciben «la gracia y la paz» ${ }^{167}$; a quien - por todos esos dones- se dirigen con sentimientos de humilde adoración y exultante glorificación ${ }^{168}$, de alabanza y bendición ${ }^{169}$, de sentido agradecimiento «continuamente y por todo» ${ }^{170}$. ¿Así vivían antes y debemos vivir ahora los hijos de Dios! Confesar que Él es «Padre» nuestro, en efecto, significa «participar de su naturaleza» o tener su «Espíritu» y «ser guiados por» él, personificación de su amor ${ }^{171}$, a fin de imitar su bondad con «malos y buenos» o su misericordiosa benevolencia "con desagradecidos y malvados»: Amando «a nuestros enemigos, para devenir [plenamente] hijos» suyos ${ }^{172}, \mathrm{y}$

149. S. Sabugal, o.c., 391-394. 150. Jn 3,16.18; 1Jn 4,9; Cf. Jn 1,14.18. 151. Cf. Jn 4,$34 ; 5,30 ; 6,38-40 ; 7,16-17 ; 8,29 ; 14,31 ; 17,4 ;$ Mc 14,36par; Jn 19,30. 152. Cf. Jn 6,57; 8,16.19; $10,30.38 ; 14,9-11 ; 15,23 ; 16,3.32 ; 17,21$. 153. Cf. Jn 3,$35 ; 10,17 ; 15,9 ; 17,23.26$. 154. Cf. Jn 3,16-17; 1Jn 4,9-10. 155. 2 Cor 1,3 ; Rm 15,6; Ef 1,3; Col 1,3; 1Pe 1,3; Cf. 2 Cor 11,31. 156. 2Cor 1,3; 1Cor 8,6: 157. Ef 1,3-10; Cf. Gál 1,4; Rm 6,4; 1Cor 15,24-28. 158. Ef 1,3.5; Gál $4,6=\operatorname{Rm~} 8,15$. 159. ITes 3,11.13; 2Tes 1,1; 2,16 Gál 1,3; Ef 1,2; 4,20; Col 1,2; Flm 3; Cf. 1Tes 1,3; Gál 1,4. 160. Mt 6,30-33par; 5,45.48par; 6,14-15 (=Mc 11,25): Cf. S. Sabugal, o.c., 397401. 161. Lc $11,2(=\mathrm{Mt} 6,9)$; Gál $4,6(=\operatorname{Rm~} 8,15)$. A este respecto, Cf.: J. Jeremias, o.c., 6465.162-64 (trad. españ., 71.225-27); Id., Theologie NT, 191s (trad. españ., 231s); S. Sabugal, o.c., 401-412. 162. Gál 3,26; 4,5-7; Rm 8,14-17; 1Jn 3,1-2; Cf. Ef 1,5; 1Pe 1,17. 163. Gál $4,6(=\operatorname{Rm} 8,14-15)$; Cf. 1 Pe 1,17 ; Ef $1,3.5$. 164. 1 Jn 3,1 ; Jds 1 ; Cf. 2 Tes 2,16 . 165. Rm 12,2; Ef 5,17; Col 1,9; 4,12; Hebr 10,36;13,21; 1Pe 2,15-16;3,17;4,1-2.19; 1Jn 2,19. 166. Mt 12,50par; 7,21; Cf. 1Jn 2,19. 167. Cf. Gál 1,3; 1Cor 1,3; 2 Cor 1,2; Rm 1,7; Ef 1,2; Fil 1,2; Flm 3. 168. Ef 3,14; Fil 2,11. 169. Cf. 2 Cor 1,3 ; Ef 1,$3 ; 1$ Pe 1,3 ; Sant 3,9 . 170. Ef 5,20 ; Cf. Col 1,3.12; 3,17. 171. $2 \mathrm{Pe} 1,4 ; \mathrm{Rm} 8,9.14-16 ; 5,5$. 172. Mt 5,44-48 (=Lc 6,27-36): Cf. S. Sabugal, o.c., 411-12; Id., Liberación..., 285-88.293.300-311. 
perdonando «a nuestros deudores» u ofensores, - «como Dios nos perdonó en Cristo»-, para recibir su perdón ${ }^{173}$. Así testimoniamos ser hijos del «Dios-es-Amor» ${ }^{174} \mathrm{e}$, irradiando la «Luz» de ese «Amor» ${ }^{175}$ ante «los hombres», cumplimos la misión de ser «la luz del mundo» y colaboramos a que aquéllos «glorifiquen a nuestro Padre celeste» ${ }^{176}$.

2. Del cual confesamos asimismo, en el Símbolo, ser «omnipotente». Entre los atributos divinos ${ }^{177}$ figuran ciertamente su eternidad ${ }^{178}$, su trascendencia y cercanía ${ }^{179}$, su espiritualidad ${ }^{180}$, omnipresencia ${ }^{181}$ y omnisciencia ${ }^{182}$, su santidad ${ }^{183}$ y justicia ${ }^{184}$, su fidelidad y veracidad ${ }^{185}$, sobre todo su misericordia y amor ${ }^{186}$. En éste - «ifuerte como la muerte es el amor!»- radica

173. Mt 6,12 (=Lc 11,4).14-15; Mc 11,25; Ef 4,32-5,1; Col 3,13: Cf. S. Sabugal, Abbá..., 64492. 174. Cf. 1 Jn 4,7-11.16. 175. Cf. 1 Jn 1,5+4,8.16. 176. Mt 5,14-16; Cf. Fil 2,14-15. La misión específica de la Iglesia, en efecto, es proclamar y practicar la misericordia del Padre: Cf. Juan Pablo II, Enc. DM VII 12-14. 177. Cf. P. van Imschoot, o.c., I 54-80; K. Rahner, ET I 129-35; J. Schneider, a.c. (DTNT I), 36-38. 178. Cf.: P. Heinisch, o.c., 36-38; M. Rehm, o.c., 36-38; P. van Imschoot, o.c., I 57s; M. Schmaus, o.c., I 508-18; M. García Cordero, o.c., I 282-87; J. Haspecker, a.c. (CFT I) 346s; J. Schneider, a.c., 36s. 179. El Dios transcendente, a quien no puede ver el hombre sin morir (Éx 33,20) y cuyo nombre es indecible (Gén 32,30; Cf. Jces 13,18), ante quien los mismos seres celestes «se cubren la faz» (Is 6,1-2) por habitar «en una luz inaccesible» (1Tim 6,6) como «Señor del cielo y de la tierra» (Mt 11,25) (Cf. a este respecto: E. Stauffer, ThWNT III 113-20; M. Rehm, o.c., 23-25; P. van Imschoot, o.c., I 56s; M. Schmaus, o.c., I 301-18; F.D. Moule, a.c. [IDB II]; 431s; A. Deissler, a.c. [DTB], 275-79; M. García Cordero, o.c., I 302-6; J. Haspecker, a.c., 345s), es a la vez el Dios cercano, del que se puede hablar antropomórficamente (Cf. supra), pues «no está lejos de nosotros» (Act 17,29) y sí está «más cerca» que los dioses lo están a sus nacionés (Dt 4,7), pues dialoga con los hombres (Gén 2,16-17; 3,9-19; 6,1ss; 12-22 etc.) y «bajó» ( isic!) a librar a Israel (Éx 3,8) con gestas históricas, teniendo sus «delicias en estar con los hijos de los hombres» (Prov 8,31), y acercándose definitivamente a ellos con la «encarnación» de su «Lógos» para «acampar entre nosotros» (Jn 1,1.14) como el «Emmanuel» o «Dios-con-nosotros» (Mt 1,23). 180. Así ya en el AT (Cf.: P. Heinisch, o.c., 29-36; P. van Imschoot, o.c., I 51-54; W. Eichrodt, o.c., I 193-201; M. García Cordero, o.c., I 298-302) y, sobre todo, en el NT: Cf. Jn 4,24; 1,$18 ; 6,46 ; 1 \mathrm{Jn} 4,12 ; 1 \mathrm{Tim} 1,17 ; 6,16$. 181. Omnipresente es el Dios revelado a Israel (Cf.: M. Rehm, o.c., 33-35; P. van Imschoot, o.c., I 60-62) y por Jesucristo: Cf. Mt 5,34-35; 6,4.6.18; 2 Cor 5,11; Ef 4,6 etc. 182. Cf.: P. Heinisch, o.c., 56s; M. Rehm, o.c., 61-64; P. van Imschoot, o.c., I 62-64; M. García Cordero, o.c., I 306-9. Un amplio estudio, al respecto, ofrece M. Schmaus, o.c., I 555-94. 183. Cf.: P. Heinisch, o.c., 39-47; P. van Imschoot, o.c., I 42-51; M. Schmaus, o.c., I 538-42.640s; B.W. Anderson, a:c., 424; A. Deissler, a.c., 279s; W. Eichrodt, o.c., I 246-57; M. García Cordero, o.c., I 220-41; J. Haspecker, a.c., 346; S. Sabugal, Abbá..., 426-30.438 (bibliogr.: 427, n. 20). 184. Cf.: P. Heinisch, o.c., 57-64; M. Rehm, o.c., 53-56; P. van Imschoot, o.c., I 71-80; M. Schmaus, o.c., I 633-37; B.W. Anderson, a.c., 246s; W. Eichrodt, o.c., I 219-28; M. García Cordero, o.c., I 241-56; J. Schneider, a.c., 37. 185. El Dios «fiel y veraz» del AT (Cf.: P. van Imschoot, o.c., I 70s; M. García Cordero, o.c., I 310-14) se autorreveló como tal plenamente en Cristo (Act 3,13-15.25-26; 13,23.32-33; Lc 1,55.72s), en quien «tuvieron su sí todas las promesas hechas por el Dios».(2Cor 1,20) que «no miente» y sí «es veraz» (Tit 1,2; Apoc 6,10), pues es «el Dios fiel»: 1 Cor 1,9; 10,13; 2Cor 1,18; Cf. 1Tes 5,24; Hebr 10,23. 186. Éstos son los atributos divinos, que más profundamente caracterizan al «Dios misericordioso y clemente» (Éx 34,6-7); autorrevelado a Israel como su «Amado» (Cant 1,13.16 etc.) y, en Cristo, como «el Padre misericordioso» (Lc 6,35-36; Ef 2,4-5 etc.) o el «Dios-es-Amor» (1Jn 4,8.16); Cf.: P. Heinisch, o.c., 64-74; M. Rehm, o.c., 57-60; P. van Imschoot, o.c., I 65-70; M. Schmaus, o.c., I 603-33; K. Rahner, ET I 135- 
precisamente la omnipotencia de Dios ${ }^{187}$, quien sin esfuerzo todo lo creó con su Palabra y es, por ello, «el Señor del cielo y de la tierra» ${ }^{188}$; el «Dios de los ejércitos». o Dominador de todas las potencias celestes y terrestres ${ }^{189}$, de los astros ${ }^{190}$ y de los fenómenos naturales ${ }^{191}$, del tiempo ${ }^{192}$ y de la vida ${ }^{193}$ : ;Señor de cuanto existe! Y Señor de la historia. Como el «Omnipotente» experimentó en la propia historia ABRAHAM al Dios, para quien «nada es imposible», pues «da la vida a los muertos» y se mostró «poderoso para cumplir lo prometido» con el don de «un hijo» a dos ancianos sexualmente muertos ${ }^{194}$; como el «Omnipotente» experimentó también ISRAEL al Dios, que le sacó de Egipto y le hizo pasar «a pie enjuto» el Mar Rojo, destruyó al ejército del faraón y le «alimentó durante 40 años en el desierto», le dio luego «la tierra» prometida tras vencer a «7 naciones más numerosas» que él..., obrando en todas esas ocasiones «signos y prodigios con mano fuerte y brazo tenso» ${ }^{195}$, no sin librarle después «con poder» del exilio babilónico ${ }^{196}$; al «poder del Altísimo», para quien «nada es imposible», se confió MARÍA de Nazaret, alabando seguidamente al «Poderoso», que en ella «hizo maravillas» ${ }^{197}$; y JESÚS reconoció en «el Padre» al «Señor del cielo y de la tierra», para quien «nada es imposible» porque «lo puede todo» ${ }^{198}$, otorgando por ello al Hijo «poder sobre toda carne» y sobre toda vida, «todo poder en el cielo y en la tierra» ${ }^{199}$. Pero la omnipotencia de Dios o «la soberana grandeza de su poder» y «la eficacia de su fuerza poderosa» se reveló culminantemente «resucitando de entre los muertos» a Jesús y «sentándole a su derecha» como Señor de todo ${ }^{200}$, manifestándose así en «la debilidad divina» de «Cristo crucificado» la «fuerza de Dios» anunciada por «el Evangelio, que [por ello] es poder de Dios para salvación de todo el que cree» ${ }^{201}$; de ahí que aquél es anunciado por los primeros evangelizadores con la fragilidad de «vasos de barro, para qué se véa que el

\footnotetext{
44; W. Eichrodt, o.c., I 213-19.228-36; M. García Cordero, o.c., I 256-71; J. Haspecker, a.c., 34850; J. Spicq L'amour de Dieu révélé aux hommes dans les écrits de saint Jean, Paris 1978; S. Verges, Dios y el hombre. La creación, Madrid 1980, 415-46; Juan Pablo II, Enc. DM 4-9. 187. A este respecto, Cf.: P. Heinisch, o.c., 47-49; O. Michel, Pantocrátor: ThWNT III 913s; M. Rehm, o.c., 26-31; P. van Imschoot, o.c., I 55s; M. Schmaus, o.c., 642-47; K. Rahner, ET I 133s; R. Schnackenburg, a.c. (DTB), 288s; J. Pfammater, Pantocrátor: MS I.2,330; W. Eichrodt, o.c., I 209-12; M. García Cordero, o.c., I 289-92; D.L. Holland, «Pantokrátor» in NT and Creed: StEv 6 (1973) 256-266. 188. Cf. Gén 1,1-31; Sal 33,6; Rm 4,17; Mt 11,25par; 5,34-35. 189. Sobre el particular, Cf. J. Hehn, o.c., 250-58; P. van Imschoot, o.c., I 20-22; W. Eichrodt, o.c., I 176-78; M. García Cordero, o.c., I 56-58. 190. Cf. Bar 3,34-35; Sal 8,4; 147,4; Is 40,26. 191. Cf. Sal 18,14-16; 29,3-10; 144,5-6; Act 14,17; 17,26; Mt 5,45, 192. Cf. Gén 8,22; Sal 74,16; Apoc 1,8; 21,6; 22,13; 1Tim 1,17. 193. Cf. 1Sam 2,6; Sal 104,29-30; Jb 34,14-15; Act 17,25-26; Rm 4,17; Mt 10,28-29par; Jn 5,26. 194. Gén 18,14; Rm 4,17.21; Hebr 11,19; Gén 15,2-6; 21,1-7. 195. Dt 4,34; Sal 136,8-12; Cf. Éx 6,6; 14,31; 15,6; Jer 32,20; Dt 6,21 etc. 196. Is 40,10 ; Jer $32,17.27$; Cf. Is $42,13-15 ; 43,16-19 ; 51,12-16 ; 52,10$ etc. 197. Lc 1,35-37.49.

198. Mt 11,25 (=Lc 10,20); 5,34-35; Mc 10,27par; 14,36. 199. Jn 17,2; 5,21.26; 10,18.29; Mt 28,18. 200. Ef 1,19-22; Cf. Act 2,32-36; Rm 4,20-24; 1Cor 15,25-27; 2 Cor 13,4; Rm 1,4; Col 2,12. 201. 1Cor 1,18.24-25.
} 
extraordinario poder [salvífico de la predicación] es de Dios y no de» ellos ${ }^{202}$ : Así experimentaron los primeros CRISTIANOS la omnipotencia del Dios, que «tiene poder para realizar todo incomparablemente mejor de lo que podemos pedir o pensar», y «es poderoso para colmarnos de todo don» ${ }^{203}$, pues «todo lo realiza conforme al designio de su voluntad» Quien «obra todo en todos» y «en todo interviene para el bien de los que le aman» ${ }^{204}$, siendo por ello reconocido y confesado por éstos como «Pantocrátor»: El Omnipotente ${ }^{205}$. Confesar que el Padre es «todopoderoso» significa, por tanto, haber experimentado - sobre todo en la propia historia-su fuerza poderosa, para resolver todo problema humanamente insoluble, para librar de toda esclavitud humanamente imposible, para dominar lo humanamente indomable y salvar lo humanamente destinado a la perdición. ¡Nada es imposible al Padre, que hizo muy buenas todas las cosas y dispone muy bien todos los eventos, que acontecen a sus hijos, pues todo - iincluso el pecado! - lo puede disponor nara el bien de quienes le aman Quien es «omnipotente»!

2022 Cor 4,7 ; Cf. 1,$21 ; 3,5$. 203. Ef 3,$20 ; 2 \operatorname{Cor} 9,8$. 204. Ef 1,11 ; 1 Cor 12,6 ; Fil 2,13; $\mathrm{Rm} 8,28$. 205. 2Cor 6,18 ; Apoc 1,$8 ; 4,8 ; 11,17 ; 15,3 ; 16.7 .14: 19,6.15 ; 21,22$. A este respecto. Cf.: O. Michel, a.c., 914; J. Pfammater, a.c., 330. 